\title{
Generic Air Sampler Probe Tests
}

\author{
J. A. Glissmeyer
}

M. W. Ligotke

November 1995

Prepared for the U.S. Department of Energy under Contract DE-AC06-76RLO 1830

Pacific Northwest Laboratory Operated for the U.S. Department of Energy by Battelle Memorial Institute 


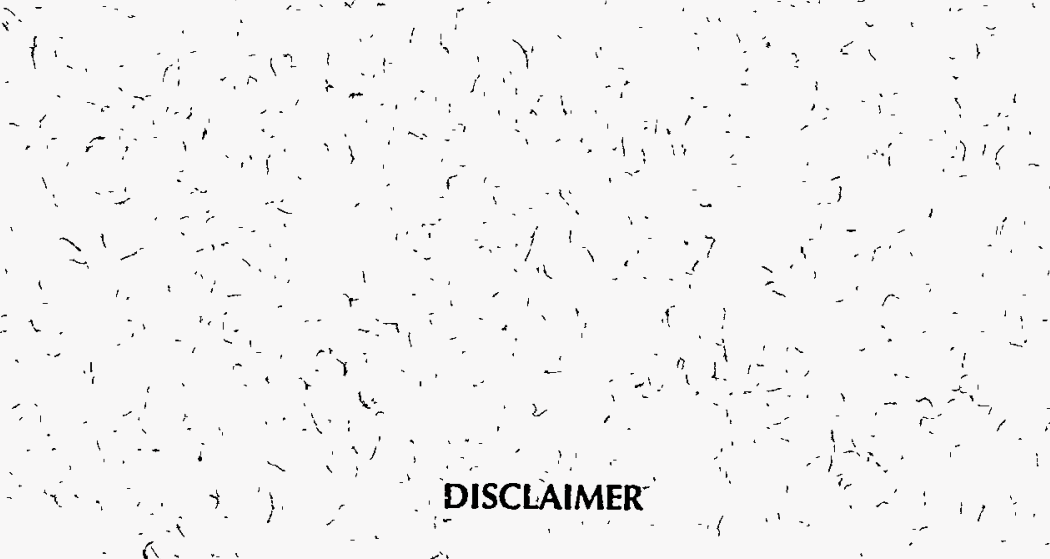

This réport was prepared as an account of work sponsored by an agency of the Uniteơ States Government. Neither the United States Government nor any agency thereof, nor Battelle Memorial Institute, nor any of their employees, makes any warranty, express or implied, or assumes any legal liability or responsibility for the accuracy, completeness, or usefulness of any information, apparatus, product, or process disclosed, or represents that its use would not infringe privately owned righits. Reference herein to any specific commercial product, process, or service by trade name, trademark, manufacturer, or otherwise does not necessarily constit,te or -imply, its endorsement, recommendation, or favoring by the United, States Gcvernment or any agency thereof, or Battelie Memorial institute. The views and opinions of authors expressed'herein do not necessarily state or reflect those of the United States Government or any agency thereof.

\section{PACIFIC NORTHWEŚT LABORATTÓRY operated by \\ BATTELLE MEMORIAL INSTITUTE for the \\ UNITED STATES DEPARTMENT OF ENERGY under Contract DE-AC06-76RLOO 1830}

Printed in the United States of America

Available to DOE and DOE contractors from the Office of Scientific and Technical Information, P.O. Box 62, Oak Ridge, TN 37831; prices available from (615) $576-8401$.

Available to the public from the National Technical Information Service, U.S. Department of Commerce, 5285 Port Royal Rd., Springfield, VA 22161 


\title{
Generic Air Sampler Probe Tests
}

\author{
J. A. Glissmeyer \\ M. W. Ligotke
}

November 1995

Prepared for

the U.S. Department of Energy

under Contract DE-AC06-76RLO 1830

Pacific Northwest Laboratory

Richland, Washington 99352

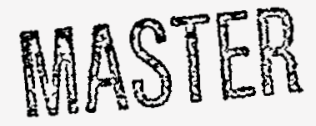

DISTRIBUTION OF THIS DOCUMENT IS UNLIMITED

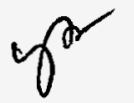





\section{Summary}

Tests were conducted to determine the best nozzle and probe designs for new air sampling systems to be installed in the ventilation systems of some of the waste tanks at the Hanford Site in Richland, Washington. Isokinetic nozzle probes and shrouded probes were tested. The test aerosol was sodiumfluorescein-tagged oleic acid. The test parameters involved particle sizes from 1 to $15 \mu \mathrm{m}$, air velocities from 3 to $15 \mathrm{~m} / \mathrm{s}$. The results of the tests show that shrouded probes can deliver samples with significantly less particle-size bias than the isokinetic nozzle probes tested. Tests were also conducted on two sample flow splitters to determine particle loss as a function of aerodynamic particle size. The particle size range covered in these tests was 5 to $15 \mu \mathrm{m}$. The results showed little particle loss, but did show a bias in particle concentration between the two outlets of each splitter for the larger particle sizes. 



\section{Acknowledgments}

This work was supported by the U.S. Department of Energy under Contract DE-AC06-76RLO 1830 with project funding through Westinghouse Hanford Company. We acknowledge the assistance of G. W. Dennis, R. B. Jarrell, T. K. O'Neil, and A. Krupsha in conducting the wind tunnel tests. 



\section{Contents}

Summary $\ldots \ldots \ldots \ldots \ldots \ldots \ldots \ldots \ldots \ldots \ldots \ldots \ldots \ldots \ldots \ldots \ldots \ldots$ iii

Acknowledgments $\ldots \ldots \ldots \ldots \ldots \ldots \ldots \ldots \ldots \ldots \ldots \ldots \ldots \ldots \ldots$

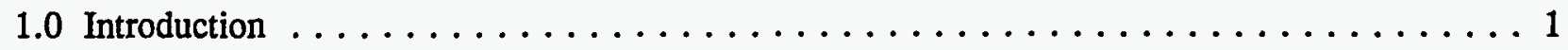

2.0 Descriptions of Sampling Components Tested $\ldots \ldots \ldots \ldots \ldots \ldots \ldots \ldots \ldots$

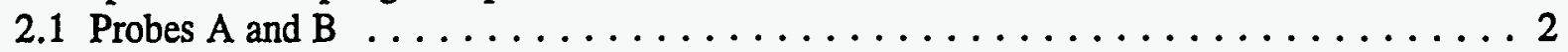

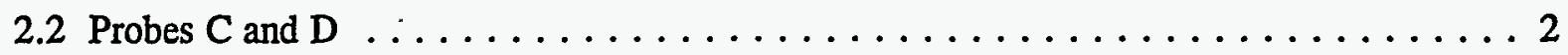

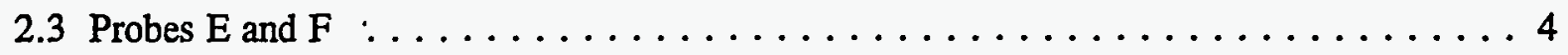

2.4 Flow Splitters $\ldots \ldots \ldots \ldots \ldots \ldots \ldots \ldots \ldots \ldots \ldots \ldots \ldots \ldots \ldots \ldots$

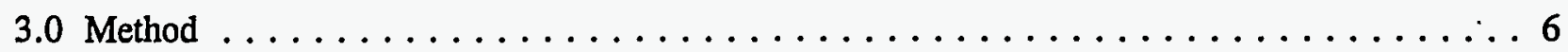

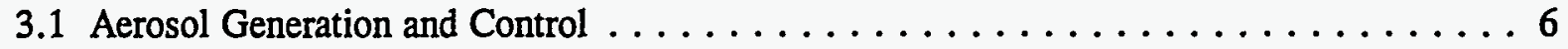

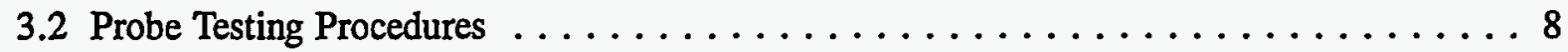

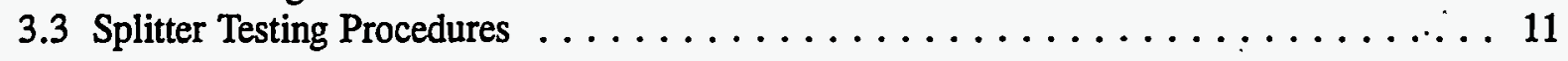

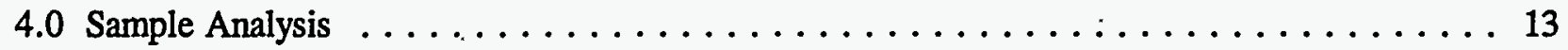

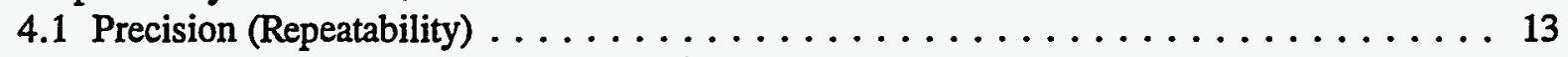

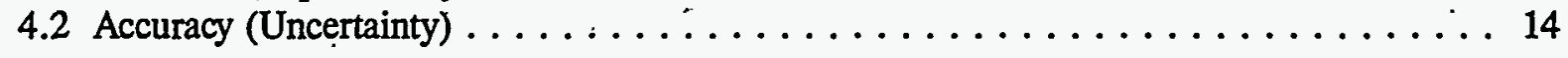

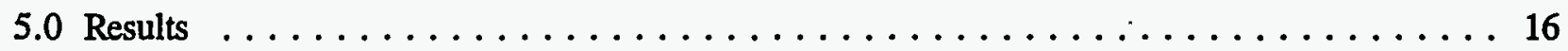

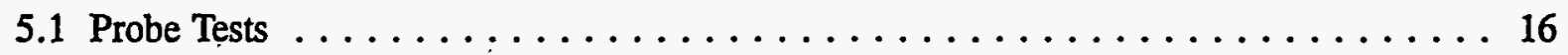

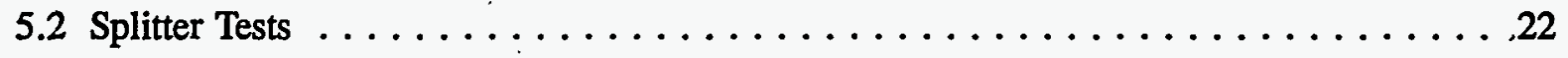

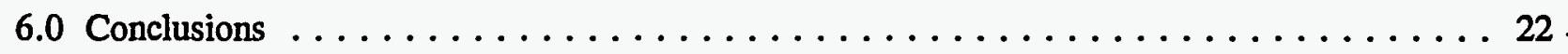

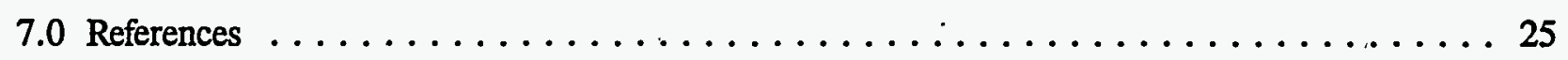

Appendix A - Summary Test and Subtest Data Tables Arranged Numerically . . . . . . . . A.1 


\section{Figures}

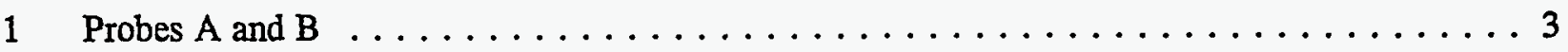

2 Features of Shrouded-Type Nozzle of Probes $C$ and $D \ldots \ldots \ldots \ldots$

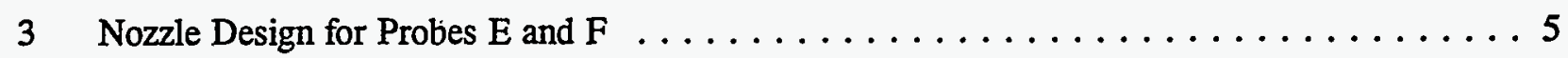

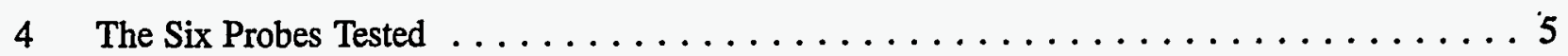

$5 \quad$ Splitter Assembly $\ldots \ldots \ldots \ldots \ldots \ldots \ldots \ldots \ldots \ldots \ldots \ldots \ldots \ldots \ldots$

6 Aerosol Generation and Neutralization $\ldots \ldots \ldots \ldots \ldots \ldots \ldots \ldots$

7 Aerosol Dispersion Manifold in Wind Tuninel $\ldots \ldots \ldots \ldots \ldots \ldots \ldots$

8 Shrouded Probes and Center Isokinetic Reference Nozzle Mounted on Wind Tunnel . . . . . . 11

9 Three Isokinetic Reference Samplers $\ldots \ldots \ldots \ldots \ldots \ldots \ldots \ldots \ldots$

10 Concentration Ratio at Filters ys. Particle Size at $5 \mathrm{~m} / \mathrm{s}$ Air Velocity . . . . . . . . . 17

11 Concentration Ratio at Filters vs. Particle Size at $15 \mathrm{~m} / \mathrm{s}$ Air Velocity $\ldots \ldots \ldots \ldots \ldots$

12 Concentration Ratio at Filters for $10-\mu \mathrm{m}$ Particles as a Function of Air Velocity $\ldots . . . . .19$

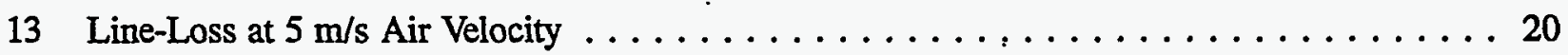

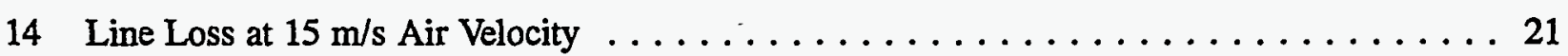

15 Splitter Performance $\ldots \ldots \ldots \ldots \ldots \ldots \ldots \ldots \ldots \ldots \ldots \ldots \ldots \ldots \ldots$

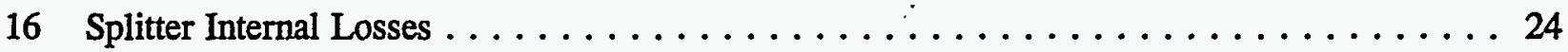

\section{Tables}

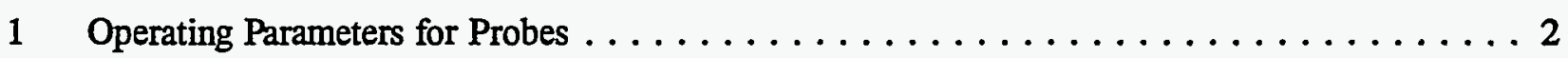

2 Target Shrouded Nozzle Test Flow Rates for Proportional Flow Mode . . . . . . . . . . . 4

3 Splitter Passage Dimensions $\ldots \ldots \ldots \ldots \ldots \ldots \ldots \ldots \ldots \ldots \ldots \ldots \ldots \ldots \ldots$

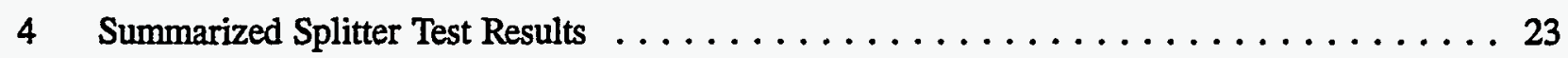

viii 


\subsection{Introduction}

On December 15, 1989, 40 CFR 61, Subpart H, "National Emission Standards for Emissions of Radionuclides Other than Radon from Department of Energy Facilities," came into effect. This regulation dictates the design of the radionuclide sample collection, measurement, and monitoring methods if the potential emission levels from an emission point could cause an off-site dose above specified levels. A generic stack sampling and monitoring system, which will comply with the regulations, is to be designed with applicability to various exhaust stacks in high-level waste tank farms at the U.S. Department of Energy's (DOE) Hanford Site. The initial application will be the 296-A-40 Stack.

The purpose of this task is to identify suitable sampling system probes, nozzles, and flow splitters for sample extraction and transport. The regulations, 40 CFR 61, Subpart H, require the use of isokinetic $^{(a)}$ probes as described in ANSI N13.1-1969 (ANSI 1982). More recent research (Rodgers et al. 1994) indicates very poor performance for isokinetic probes and shows improved performance using a shrouded probe. The U.S. Environmental Protection Agency (EPA) recently approved a DOE petition that allows the use of a single shrouded probe in applications that previously required a manifold using several isokinetic probes. A recently acquired sampling system, for the rotary mode core drill exhauster at Hanford, uses constant subisokinetic ratio nozzles.

These three types of probes (isokinetic, shrouded, and subisokinetic) were tested in the Pacific Northwest Laboratory (PNL) wind tunnel facility to determine their relative performance. The test matrix included a broad range of particle sizes, air velocities, flow rates, and the classic and newer nozzle designs. A series of flow splitters designed at the Hanford Site were also tested for particle deposition over a range of particle size.

\subsection{Descriptions of Sampling Components Tested}

The probes tested were of the simplest possible configuration for use at stacks with diameters less than $37 \mathrm{~cm}$, with one or two nozzles and a short transport line leading to the filter holder mounted just outside the stack. In all, six sampling probes were tested (denoted A through F). Table 1 shows some of the key probe nozzle characteristics and the target operating flow rates for the tests. The probes and flow splitters are described in detail in the following sections.

(a) Air samples are extracted from the bulk airflow through a probe having a round orifice that is aerodynamically designed. The opening is generally pointed directly into the airflow. The term isokinetic means that the air velocity through the probe orifice matches that of the approaching airstream. This theoretically ensures that the sample airstream has the same concentration of particles of all sizes per unit air volume as the bulk airstream. If the probe orifice air velocity is lower than that of the bulk airstream, it is operating "subisokinetically." In this case, particles with significant inertia will be present in the sample airstream in a concentration greater than in the bulk airstream. 
Table 1. Operating Parameters for Probes

\begin{tabular}{|c|c|c|c|c|c|c|}
\hline & A & $\mathbf{B}$ & C & $\mathbf{D}$ & $\mathbf{E}$ & $\mathbf{F}$ \\
\hline & $\begin{array}{c}\text { Shrouded } 2 \text { Nozzle } \\
\text { Isokinetic Probe }\end{array}$ & $\begin{array}{l}\text { ANSI } 2 \text { Nozzle } \\
\text { Isokinetic Probe }\end{array}$ & $\begin{array}{l}\text { Fixed } 2 \mathrm{cfm} \text { Low Range } \\
\text { Shrouded Probe }\end{array}$ & $\begin{array}{c}\text { Fixed } 2 \mathrm{cfm} \text { High Range } \\
\text { Shrouded Probe }\end{array}$ & $\begin{array}{c}\text { Fixed Subisokinetic } \\
\text { Ratio Probe }\end{array}$ & $\begin{array}{l}\text { ANSI Probe } \\
\text { Isokinetic }\end{array}$ \\
\hline Inlet diameter $(\mathrm{cm})$ & 0.853 & 0.853 & 3.099 & 1.829 & 1.151 & 0.886 \\
\hline Inlet square $(\mathrm{cm})$ & 0.572 & 0.572 & 7.542 & 2.627 & 1.040 & 0.617 \\
\hline Isokinetic ratio & 0.81 & 0.81 & NA & NA & 0.593 & 1 \\
\hline Number of nozzles & 2 & 2 & 1 & 1 & 1 & 1 \\
\hline Air velocity $(\mathrm{m} / \mathrm{sec})$ & \multicolumn{6}{|c|}{ Operating flow rate corresponding to air velocity (L/min) } \\
\hline 5 & 28 & 28 & 57 & 57 & 17 & 17 \\
\hline 10 & 55 & 55 & 57 & 57 & 34 & 34 \\
\hline 15 & 83 & 83 & 57 & 57 & 52 & 52 \\
\hline
\end{tabular}

\subsection{Probes A and B}

Both probes A and B consisted of two nozzles mounted on a common transport tube as shown in Figure 1. They were designed for isokinetic sampling with a flow rate of $62 \mathrm{~L} / \mathrm{min}(2.2 \mathrm{cfm})$ from an airstream velocity of $4.9 \mathrm{~m} / \mathrm{s}(955 \mathrm{ft} / \mathrm{min})$. The difference between the two probes was that probe A has a short shroud (or open-ended tube) mounted just upstream of the nozzle inlet while probe B has no shroud. The purpose of the shroud is to force the turbulent airstream approaching the nozzle into alignment with the nozzle axis, reducing the turbulent impaction of particles at the edge of the inlet. The nozzles of both probes had sharp-edged orifices and an internal expansion taper of $8^{\circ}$ to help reduce turbulence-induced impaction just inside the orifice. Typical ANSI N13.1 design would have a curved tube connecting the nozzle to the manifold; however; here the nozzles are welded perpendicular to the manifold pipe through which the sample stream exits the stack. The external taper from the nozzle leading edge was more blunt than typical for isokinetic probes. The external taper from the orifice to the outside diameter of the nozzle was about $30^{\circ}$. To maintain isokinetic operation when the bulk airstream velocity varied, the flow rate through an isokinetic probe was varied in proportion to the airstream velocity. This is termed "proportional or variable flow mode."

The intent was to test these probes when operated isokinetically. However, because of an initial error in measuring the nozzle opening, the test conditions that were established resulted in operating these probes slightly subisokinetically (i.e., with the ratio of air velocity in the opening to that in the free stream being about 0.81 .). This error should result with the sample filters collecting slightly more particles larger than $2 \mu \mathrm{m}$ than would otherwise be the case. The actual test conditions are shown in Table 1. For isokinetic operation, the sample flow rates should have been about $24 \%$ greater than those shown.

\subsection{Probes C and D}

Probes $\mathrm{C}$ and $\mathrm{D}$ both had a shrouded probe single inlet nozzle, shown in Figure 2, as described by McFarland et al. (1989). Probe $C$ was designed for a sample flow rate of $57 \mathrm{~L} / \mathrm{min}$ at an airstream velocity of 2.5 to $8.5 \mathrm{~m} / \mathrm{s}$. Probe $\mathrm{D}$ was designed for the same flow rate at an airstream velocity of 8 to 


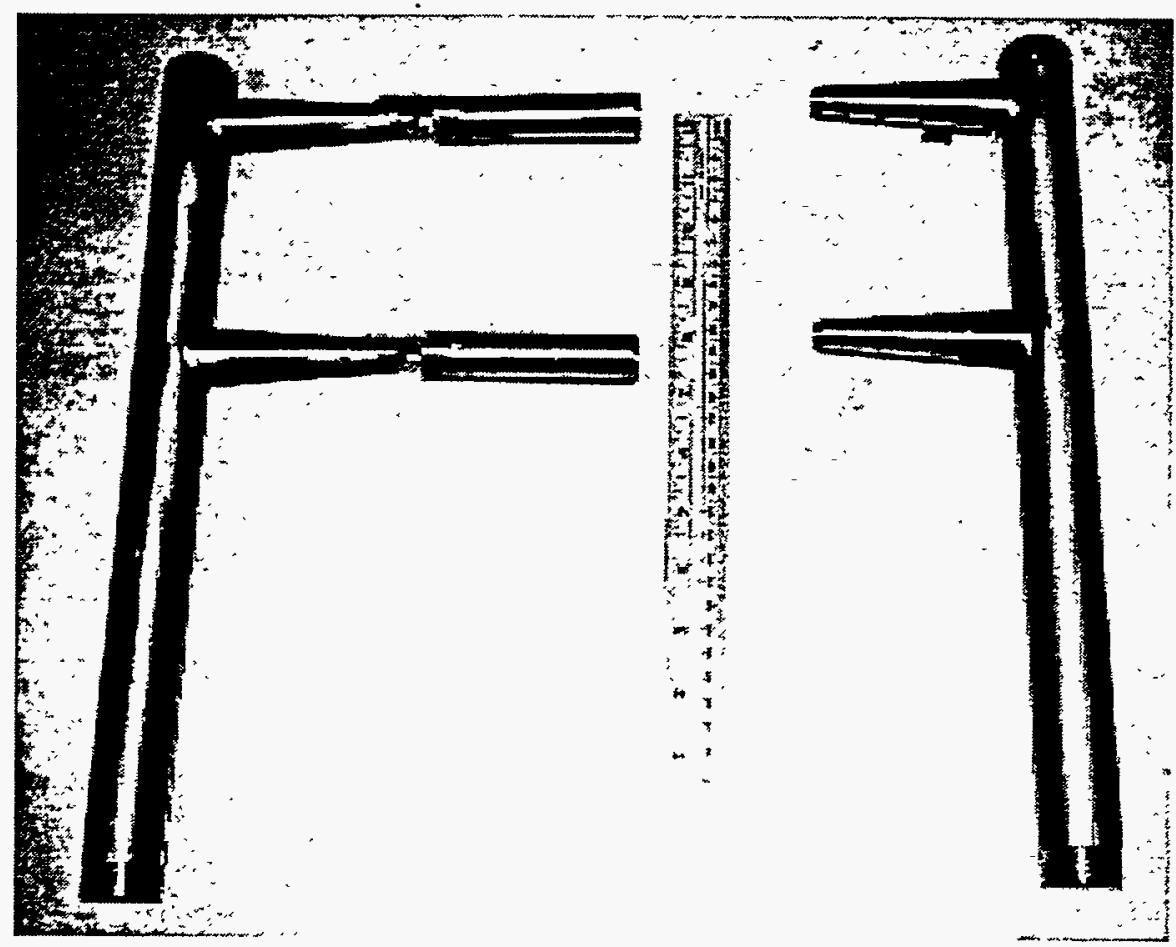

Figure 1. Probes A and B

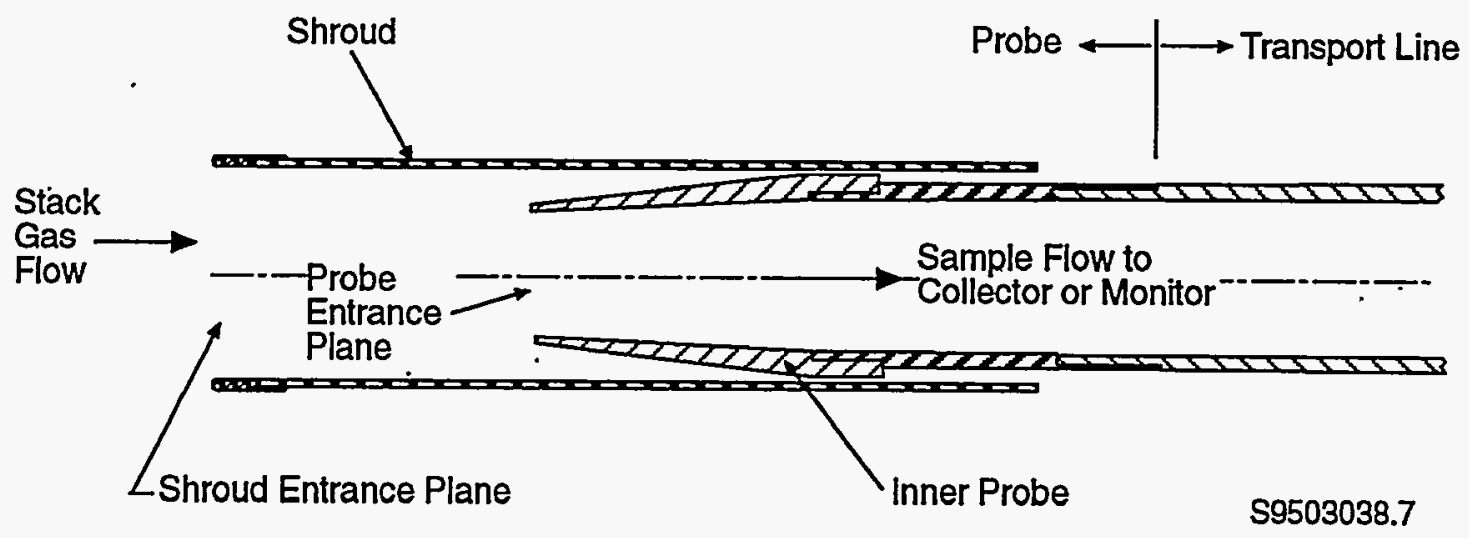

Figure 2. Features of Shrouded-Type Nozzle of Probes C and D

$16 \mathrm{~m} / \mathrm{s}$. The main difference between the two was the diameter of the nozzle inlet. These probes did not follow the usual convention of isokinetic sample aspiration but were designed to operate at a fixed flow rate over a range of airstream velocities. The shroud aligned the air velocity with the axis of the nozzle and decelerated the velocity of the approaching airstream. The large-diameter nozzle aspirated the sample from the central portion of the airstream, well away from the turbulence caused by the shroud's leading edge and walls. The transport line consisted of a large radius $90^{\circ}$ bend; a short, straight section; and internally tapered adapters to accommodate the nozzle and filter holder. These probes were tested both in their normal fixed-flow rate mode and in a mode where the flow rate was 
varied in proportion to the air velocity. Table 2 lists the target test flow rates for the proportional flow mode. The design flow rate was assumed to be the target when the nozzle was used at the midpoint of its operating range.

\subsection{Probes $E$ and $F$}

Probes $\mathrm{E}$ and $\mathrm{F}$ consisted of a single nozzle of the type shown in Figure 3. Probe $\mathrm{F}$ was designed to extract samples isokinetically at $42.4 \mathrm{~L} / \mathrm{min}$ from an airstream velocity of $11.5 \mathrm{~m} / \mathrm{s}$. Probe $\mathrm{E}$ was identical except it had a larger inlet diameter so the intake-to-airstream velocity ratio would be 0.59 . Thus, probe E would operate subisokinetically, which would theoretically cause the sample airstream to be enriched in particles larger than approximately $2 \mu \mathrm{m}$ aerodynamic equivalent diameters (AED). (This probe was identical to the probe used in Westinghouse Hanford Company's Rotary Mode Core Sampler exhaust system.) The nozzle design was otherwise similar to that of probe B. To maintain a constant airstream-to-nozzle-opening velocity ratio, the flow rate through both of these probes was varied in proportion to the airstream velocity.

Figure 4 shows all of the tested probes. The shrouded probes are shown with the nozzles disassembled.

\subsection{Flow Splitters}

Splitters are sometimes used to subdivide the sample stream from a single probe for the collection of different types of samples. Two splitter designs (Hanford Drawing H-2-92504) were tested: 1) to divide $170 \mathrm{~L} / \mathrm{min}(6 \mathrm{cfm})$ into separate 113 and $57 \mathrm{~L} / \mathrm{min}(4$ and $2 \mathrm{cfm}$ ) streams, and 2) to divide $113 \mathrm{~L} / \mathrm{min}(4 \mathrm{cfm})$ into two $57 \mathrm{~L} / \mathrm{min}(2 \mathrm{cfm})$ streams. The splitters were designed to be used in series so a sample flow rate of $170 \mathrm{~L} / \mathrm{min}(6 \mathrm{cfm})$ could be subdivided into three $57-\mathrm{L} / \mathrm{min}(2-\mathrm{cm})$ sample

Table 2. Target Shrouded Nozzle Test Flow Rates for Proportional Flow Mode

\begin{tabular}{||c|c|c|}
\hline Design air speed range $(\mathrm{m} / \mathrm{s})$ & $2.5-8.5$ & $8-16$ \\
\hline Range midpoint $(\mathrm{m} / \mathrm{s})$ & 4.5 & 12 \\
\hline \multirow{2}{*}{$\begin{array}{c}\text { Air Speed } \\
(\mathrm{m} / \mathrm{s})\end{array}$} & $\mathrm{C}$ &. $\mathrm{D}$ \\
\hline 3 & 38 & 14 \\
\hline 5 & 63 & 24 \\
\hline \hline 8 & & 38 \\
\hline 10 & & 47 \\
\hline 12 & & 57 \\
\hline 15 & & 71 \\
\hline
\end{tabular}




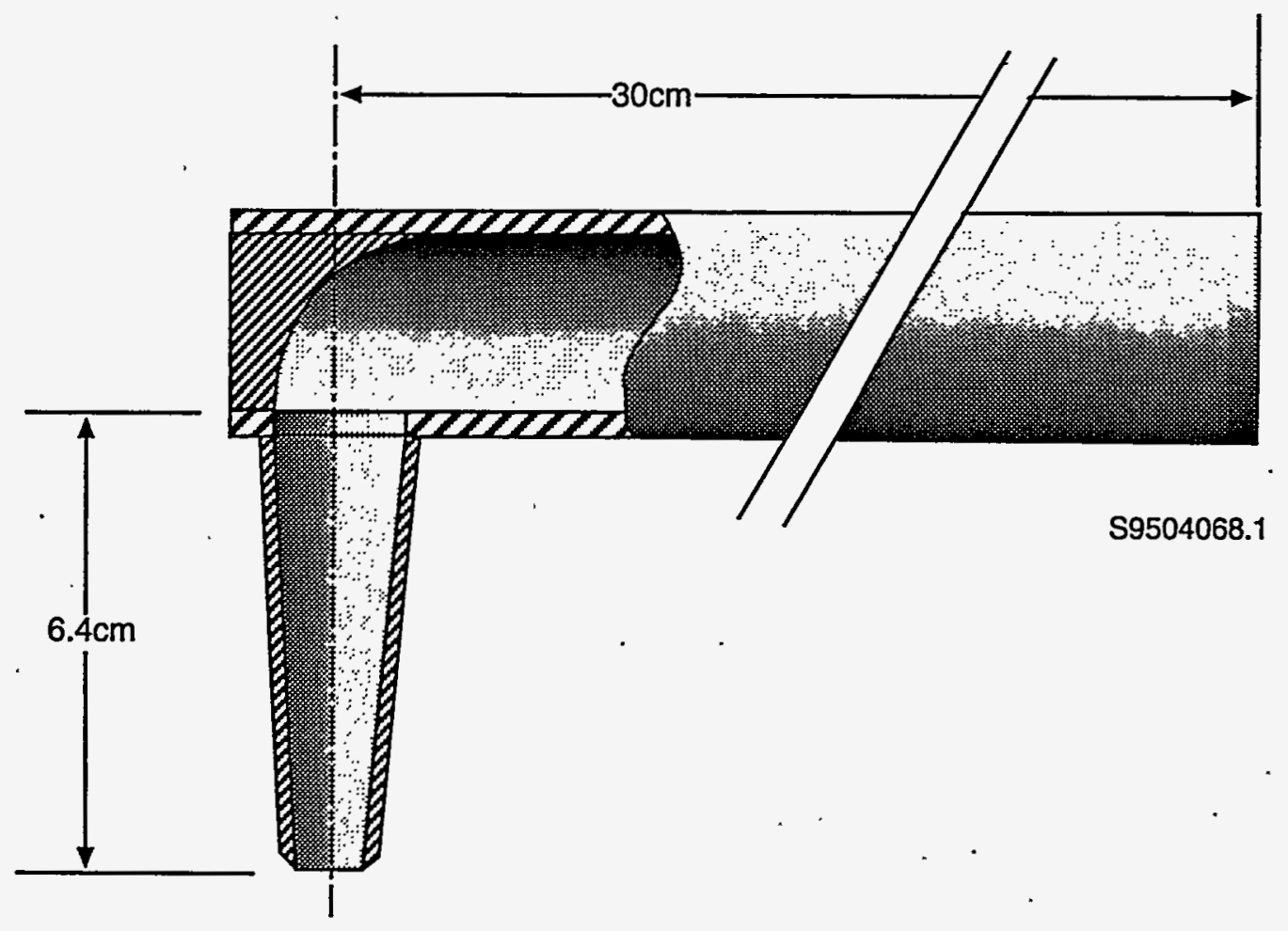

Figure 3. Nozzle Design for Probes E and F

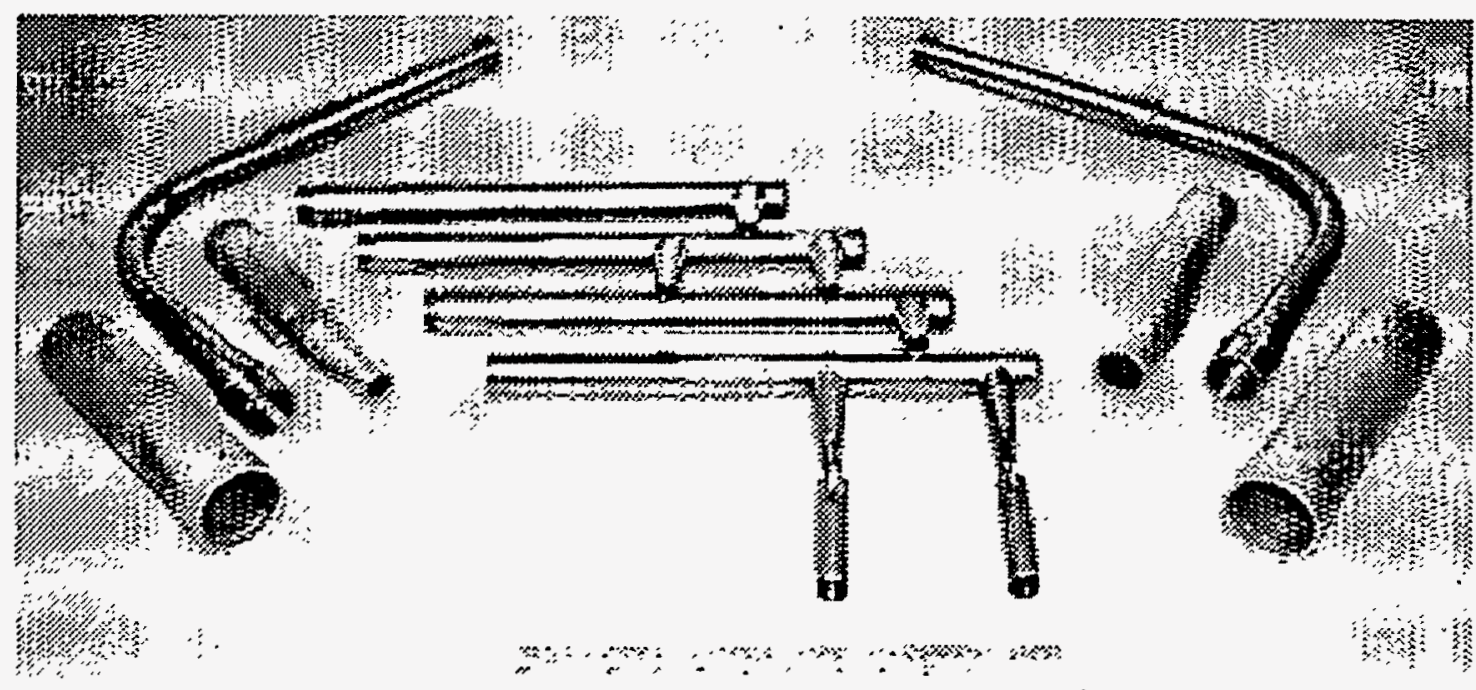

Figure 4. The Six Probes Tested 
flows. The splitters are shown in Figure 5. The angle between the outlet legs is $30^{\circ}$, and each leg is identified (Figure 5). The internal passages have circular cross sections, and the dimensions are tabulated in Table 3. The inlet of each splitter tapers into the region of the split. The ratios between the cross sectional areas equal the ratios between the outlet flow rates.

\subsection{Method}

The testing was conducted in a recirculating wind tunnel with a test section that is $0.61-\mathrm{m}$ square and 6.1-m long. The test aerosol was sodium-fluorescein-tagged oleic acid generated with a vibrating orifice aerosol generator: Each probe was tested at air velocities from 3 to $15 \mathrm{~m} / \mathrm{s}$ and particle sizes from 1 to $15 \mu \mathrm{m}$. A filter holder was attached to the end of the transport line just outside the wind tunnel wall and 47-mm-diameter glass fiber filters were used for collecting particles that were transmitted through the probes. The particle collection on the filter was dissolved in methanol, and the fluorescence content of the solution was analyzed with a spectrofluorometer. Aerosol collected on the inside surfaces of the probes was removed with the same solution and then analyzed in the spectrofluorometer. The flow splitters were tested in a similar manner except that the test particles were sampled from a gently mixed chamber within the wind tunnel.

\subsection{Aerosol Generation and Control}

Monodisperse test aerosol particles of oleic acid and the fluorescent tagged sodium fluorescein (uranine) were created from methanol-based solutions using a vibrating orifice aerosol generator. The concentration of oleic acid and uranine in each solution was controlled at a specific level, ranging from $0.001 \%$ to $6 \%$; this allowed particles with diameters between 1 and $15 \mu \mathrm{m}$ to be generated. The concentration of uranine was typically $1 \%$ to $4 \%$ of the concentration of oleic acid and depended on the size of particles to be generated. The single exception to this rule was the solution for $1-\mu \mathrm{m}$ particles which contained equal quantities of uranine and oleic acid; this change was made to ensure an adequate quantity of tracer would be collected during the probe tests. In the generator, known flow rates of solutions were passed through an $\sim 20-\mu \mathrm{m}$ circular orifice to form a cylindrical jet. A piezoelectric crystal positioned on the orifice assembly was oscillated at known frequencies to cause the liquid jet to break up into uniformly sized droplets. As the methanol in the droplets evaporated, compressed air flows were used to disperse the particles to avoid coagulation. After generation, the dispersed monodisperse particles were passed to the distributing manifold in the test section via a 2.5 -mCi krypton-85 static charge neutralizer to reduce the electrical charge on the particles to approximate a Boltzmann equilibrium charge distribution. Figure 6 shows the aerosol generator and charge neutralizer. Figure 7 shows the distributing manifold inside the wind tunnel.

The final diameter of the monodisperse particles was calculated from the solute (oleic acid and uranine) concentration, the solution flow rate, and the frequency of oscillation. Particle size and quality were also checked using one or both of two diagnostic methods (survey of particles deposited to a coated slide using a light microscope, and measurement of optical particle size and particle size distribution using a clean room counter). Particle quality was determined as the ratio of doublet ${ }^{\circ}$ particles (formed when two particles collided and coagulated) to singlet particles. Final particle density 


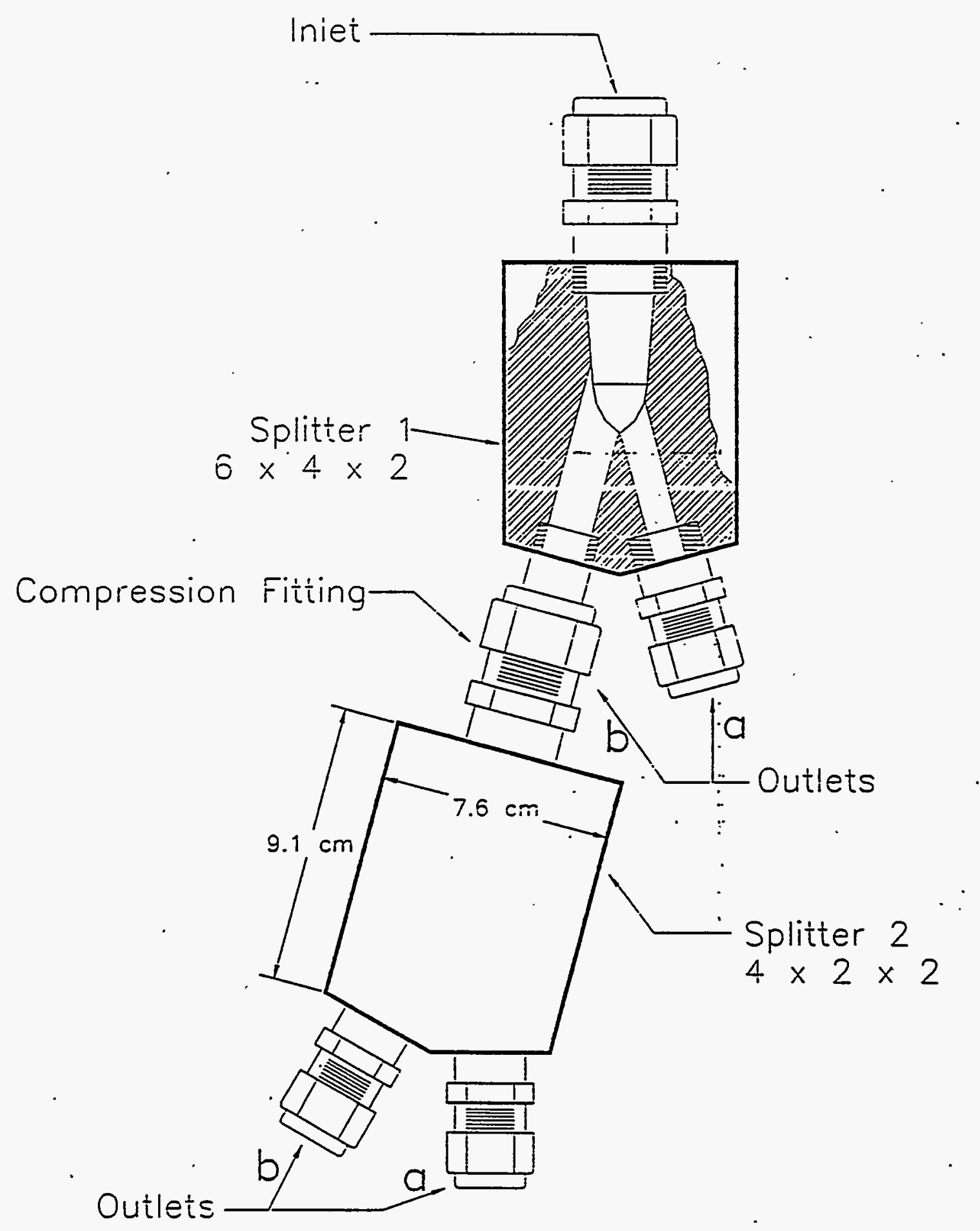

Figure 5. Splitter Assembly 
Table 3. Splitter Passage Dimensions

\begin{tabular}{|c|c|c|c|c|}
\hline \multicolumn{5}{|c|}{ Splitter 1} \\
\hline & \multicolumn{2}{|c|}{ Inside } & \multicolumn{2}{|c|}{ Area Ratio } \\
\hline & Diameter $(\mathrm{cm})$ & Area $\left(\mathrm{cm}^{2}\right)$ & To Inlet & To Taper \\
\hline Inlet & 2.24 & 3.92 & 1.00 & 1.58 \\
\hline Taper & 1.78 & 2.48 & 0.63 & 1.00 \\
\hline Leg a & 1.47 & 1.70 & 0.43 & 0.69 \\
\hline Leg $b$ & 1.04 & 0.85 & 0.22 & 0.34 \\
\hline \multicolumn{5}{|c|}{ Splitter 2} \\
\hline & \multicolumn{2}{|c|}{ Inside } & \multicolumn{2}{|c|}{ Area Ratio } \\
\hline & Diameter $(\mathrm{cm})$ & Area $\left(\mathrm{cm}^{2}\right)$ & To Inlet & To Taper \\
\hline Inlet & 1.60 & 2.01 & 1.00 & 1.18 \\
\hline Taper & 1.47 & 1.70 & 0.85 & 1.00 \\
\hline Leg a & 1.04 & 0.85 & 0.42 & 0.50 \\
\hline Leg b & 1.04 & 0.85 & 0.42 & 0.50 \\
\hline
\end{tabular}

(oleic acid and uranine) was calculated and used to determine the aerodynamic size of the monodisperse particles during each test. Target aerodynamic particle sizes were $1,5,10$, and $15 \mu \mathrm{m}$. Actual . aerodynamic particle sizes were generally within $\pm 1 \mu \mathrm{m}$ of the target values and varied depending on actual solution composition, flow rate, and oscillation frequency. Particle size was generally known within $\pm 10 \%$ (approximately $\pm 50 \%$ for the $1-\mu \mathrm{m}$ particles).

\subsection{Probe Testing Procedures}

The six probes were tested according to a matrix of parameters. The matrix specified probe type, particle size, air velocity, sample flow rate, and replication requirements. The probes each consisted of one or more nozzles, a transport line with a $90^{\circ}$ bend (sharp or gradual), and a Gelman ${ }^{(a)}$ 47-mm filter holder (containing Gelman Type A/E glass fiber filters). The probes were mounted to one vertical wall of the test section and oriented into the air flow as shown in Figure 8. The filter holders were external to the wind tunnel, just outside the vertical wall of the test section. Tests were performed using an isokinetic reference nozzle (IRN) at the vertical centerline of the test section and two probes in the test section, one above and one below the IRN. In addition, tests P10 through P23 were performed with two additional IRN that were alternately placed in the locations of the sample probes, as shown in Figure 9. The IRN differed from the sample probes primarily by having a sharp-edged inlet nozzle followed immediately by a 47-mm Gelman glass fiber filter; the IRN were always operated isokinetically. Consequently, negligible sampling bias and internal losses were exhibited in the IRN, and the analysis of the filter indicated a true measure of the relative aerosol concentration in the wind tunnel.

(a) Gelman is a registered trademark of Gelman Sciences, Inc. 


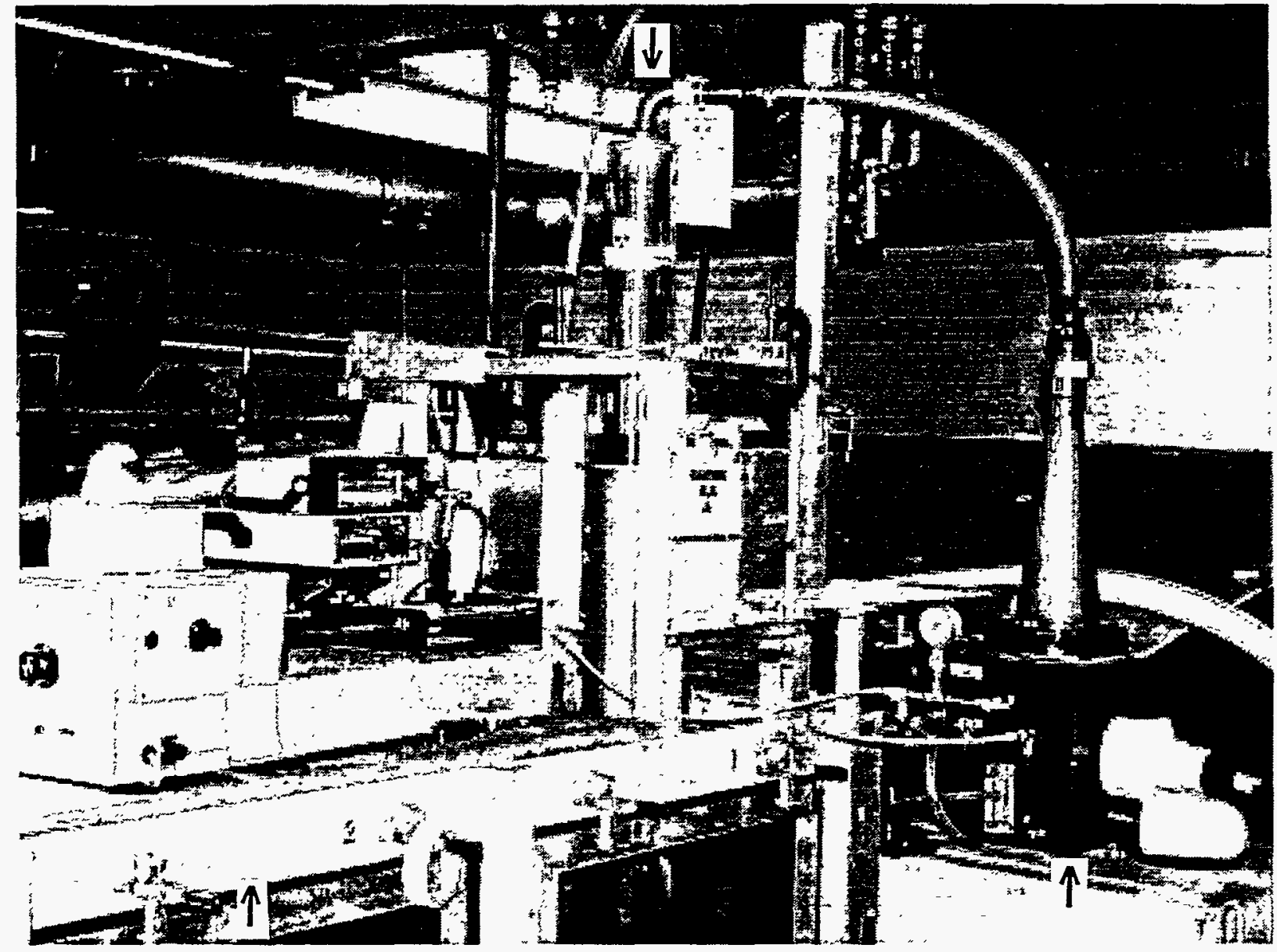

Wind Tunnel Figure 6. Aerosol Generation and Neutralization

Aerosol Generator

Tests were performed in September 1994 and in February and March 1995. Each test included a number of subtests. Tests were defined by the selection of particle size and included a number of other parameter combinations (e.g., probes could be exposed to two wind speeds during a single "test"). In all cases, each subtest performed with probes included two sample probes and one IRN at the vertical test section centerline $(30.5-\mathrm{cm}$ height). The probes were mounted $5.7 \mathrm{~cm}(1994)$ or $11.4 \mathrm{~cm}(1995)$ above and below the IRN. Beginning with test P11, such subtests were generally bracketed in time with subtests performed with the sample probes replaced by IRNs. Thus, during the subtests with only IRN, two of the IRN were sampling air at the same locations the probes were placed when in the wind tunnel as shown in Figure 8. For example, test P13 included eight subtests of probes C $C$ and D performed at an aerodynamic particle size of $10.5 \mu \mathrm{m}$. Tests P13-1 through P13-4 were performed at $5 \mathrm{~m} / \mathrm{s}$, and tests P13-5 through P13-8 were performed at $15 \mathrm{~m} / \mathrm{s}$. Test P13-1 was performed with three IRN in place. Tests P13-2 and P13-3 were performed after probe D was installed in place of the upper IRN and probe $C$ was installed in place of the lower IRN; the center IRN was not moved during all of the subtests. Test P13-4 was then a repeat of P13-1. Finally, tests P13-5 through P13-8 were performed using similar probe placements but at the greater wind speed.

Sample flow rates were controlled manually and set to values that provided isokinetic conditions in the IRN during all subtests. The flow rates in the sample probes were similarly controlled at the target 


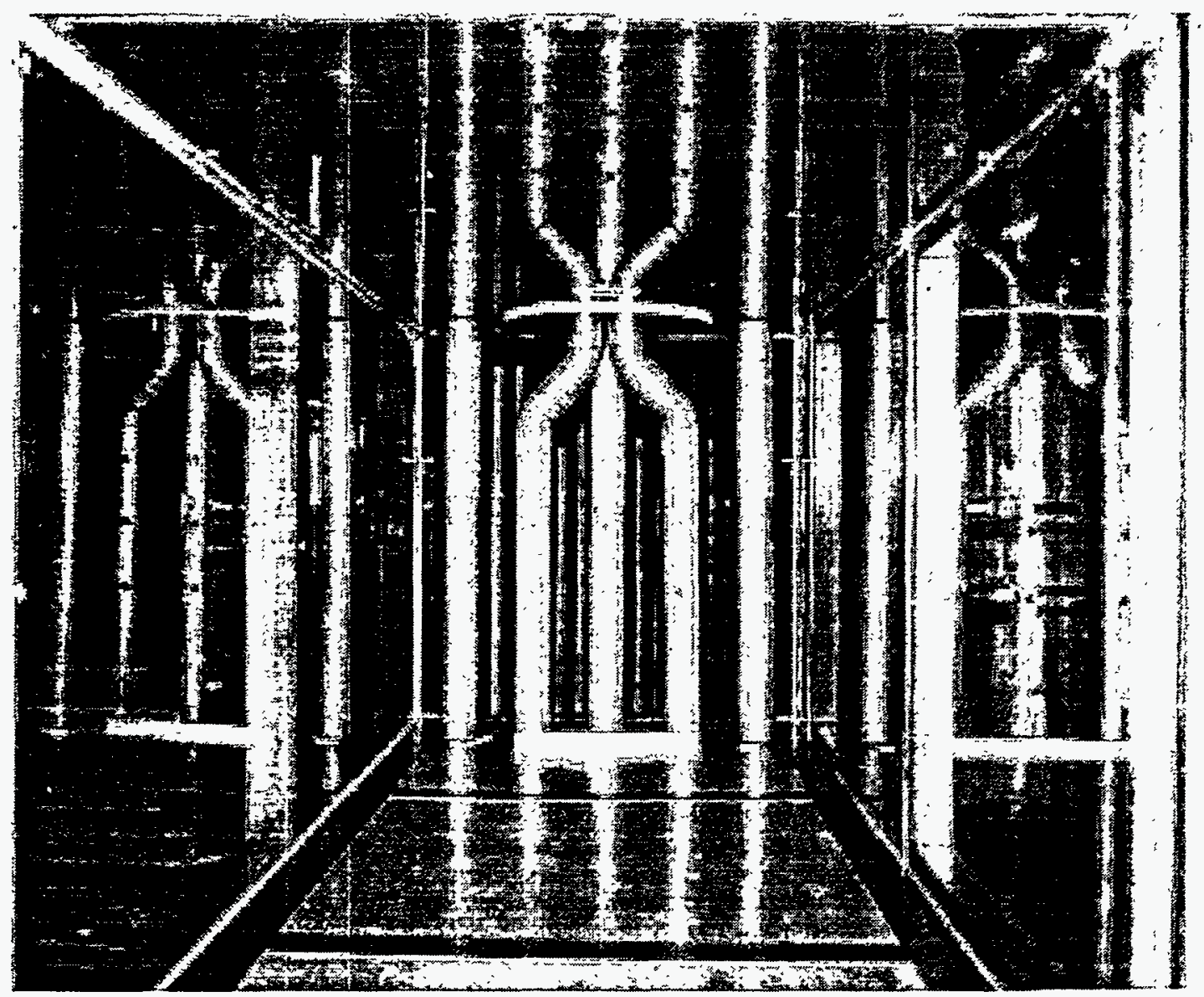

Figure 7. Aerosol Dispersion Manifold in Wind Tunnel

flow rates defined in the test matrix. Some probes were operated isokinetically; some were operated at variable or fixed subisokinetic ratios. Sample flow rate was measured by mass flowmeters calibrated in place by comparison with a similar mass flowmeter that had been calibrated by the on-site calibrations laboratory. For the in-place calibrations, the calibrated mass flowmeter was placed in the wind tunnel and connected to the sample lines attached to each of the three in-use mass flowmeters.

The procedure followed for each subtest was generally constant; any significant deviations from the procedure were recorded on the data sheet. After installation of the probes, the orientation and elevations were confirmed. Filters were installed immediately behind the IRN (in the wind tunnel) and after the sample probe body tubes (outside the side of the wind tunnel). Target sample flow rates were confirmed using an operator aid constructed from the test plan and the result of flowmeter calibrations. The three mass flowmeters were adjusted to the target levels and then the sample lines were connected to the IRN and sample probes. The aerosol generator was checked to confirm particle production and dispersion into the wind tunnel. Before selected tests, the particle quality was confirmed as described in Section 3.1. The wind tunnel fan was turned on $30 \mathrm{~s}$ before starting the subtest; wind speed data were collected at five evenly spaced intervals throughout the 10-min subtests. Subtests were initiated by opening the sample control valves. The mass flowmeter readings were observed during each subtest and average values were recorded. Temperature and relative humidity values were recorded. Wind 

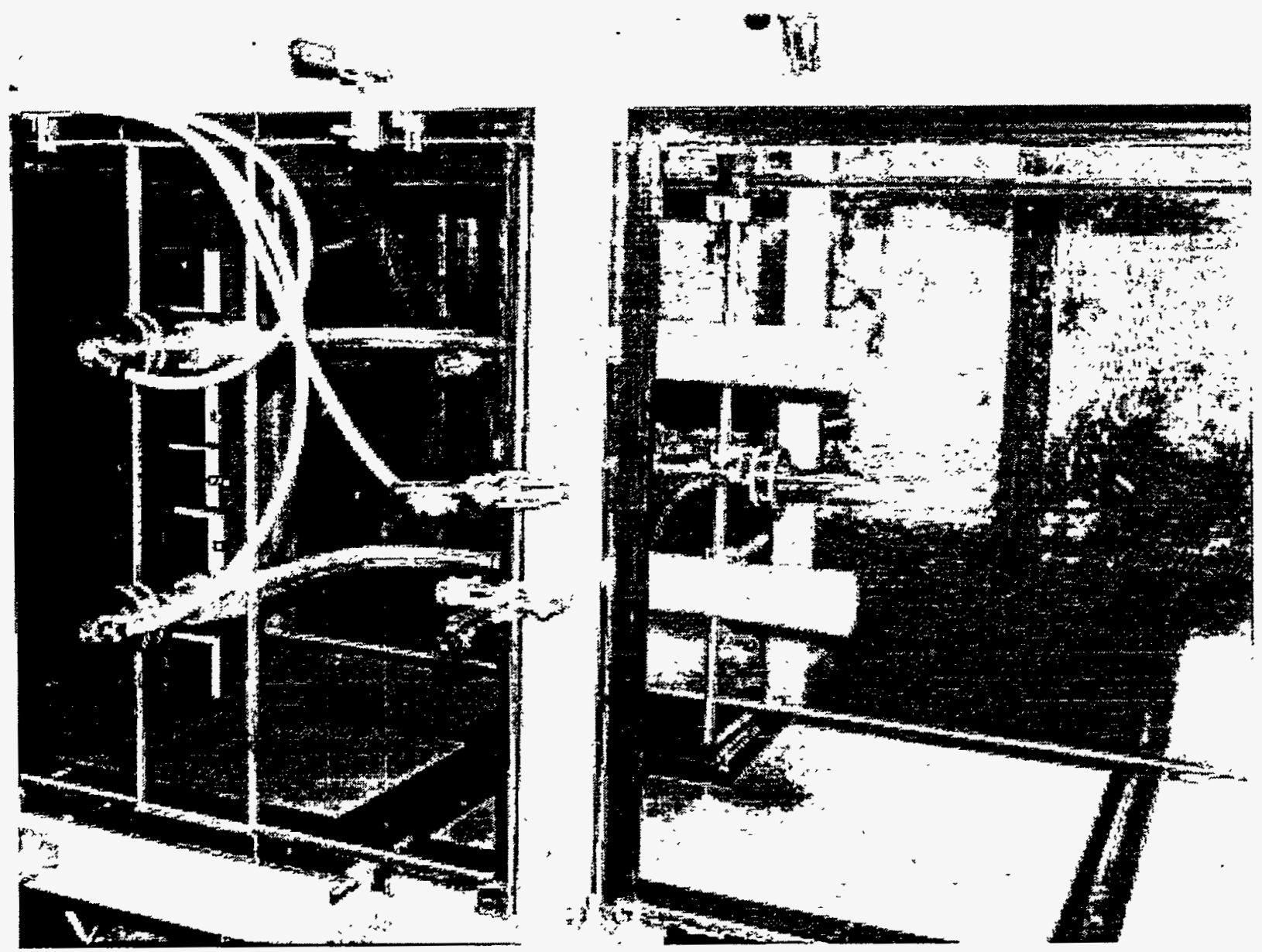

Figure 8. Shrouded Probes and Center Isokinetic Reference Nozzle Mounted on Wind Tunnel

speed was adjusted to maintain it within $\sim 0.1 \mathrm{~m} / \mathrm{s}$ of the target speeds $(3,5,8,10,12$, and $15 \mathrm{~m} / \mathrm{s})$. Subtests were terminated by closing the sample control valves. After each subtest, the filters were removed and placed into $150-\mathrm{mL}$ beakers for later analysis. The beakers were kept covered to minimize the chance for contamination. After the final subtest in each test, the aerosol generator was again confirmed to ensure particles were generated throughout the duration of each subtest. The activity of the charge neutralizer was confirmed before and after each day's tests.

\subsection{Splitter Testing Procedures}

The splitters were tested in the wind tunnel using the same aerosol generation, flow rate control, and fluoroscopy methods used to test the sample probes. Tests were performed by varying only particle size; however, wind speed was not a variable that influenced the results. A 22.9-cm-long, smoothwalled stainless steel inlet tube with an inner bevel on the inlet end was attached to splitter 1 . Splitter 1 (and the inlet tube) was then positioned horizontally with only the inlet tube penetrating into the test section of the wind tunnel. The flat dimension of the splitter body was oriented horizontally also (both 


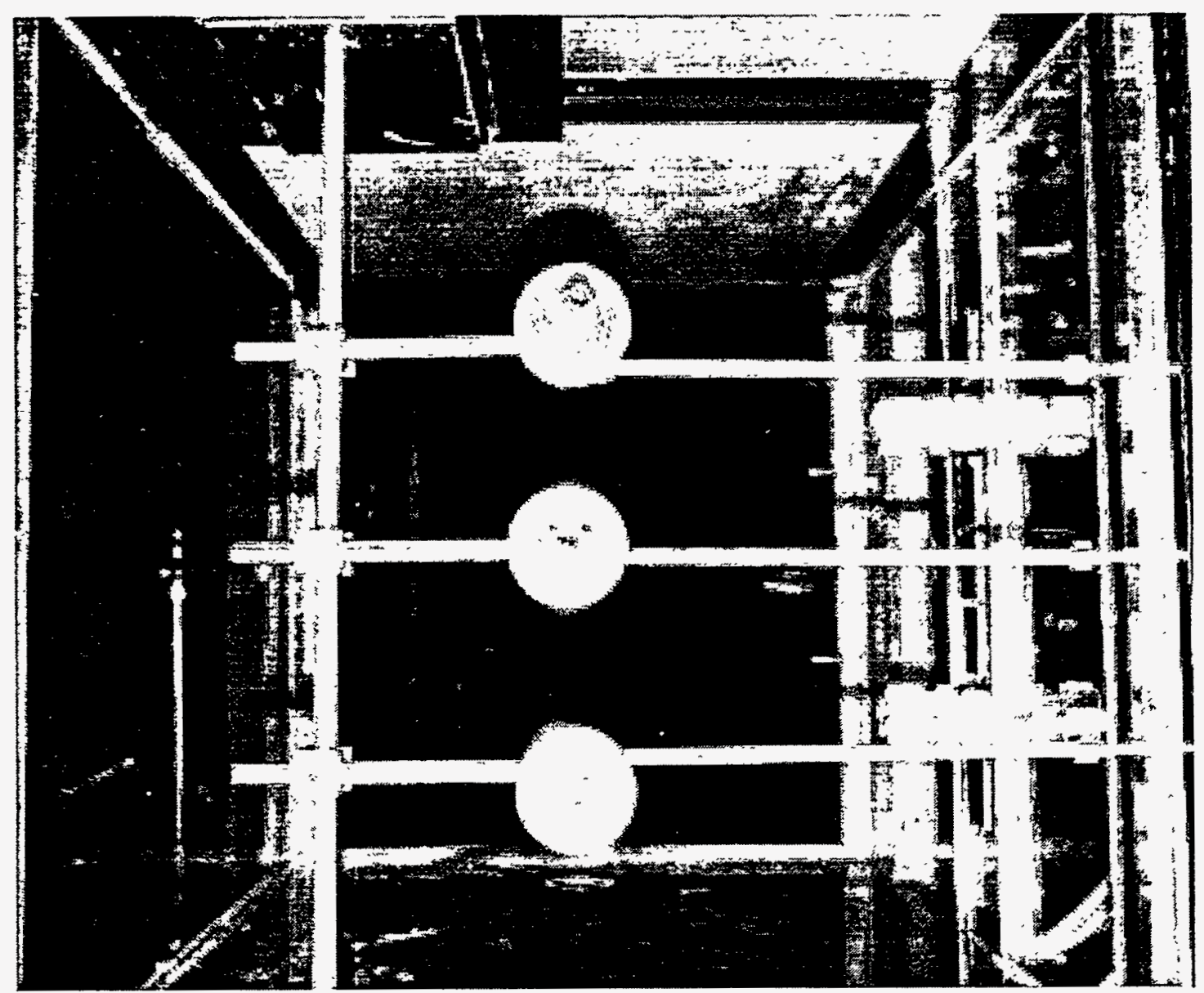

Figure 9. Three Isokinetic Reference Samplers

outlet legs at the same elevation). Splitter 2 was then attached to the large "b" outlet leg of splitter 1 using a 4.1-cm-long smooth-walled stainless steel tube as a connector. The orientation of splitter 2 was the same as splitter 1 . Three 47-mm in-line stainless steel Gelman filter holders were connected to the three open outlet legs (1a, 2a, and $2 \mathrm{~b}$ ). Sample flow rates were controlled using the same mass flowmeters used to test the sample probes. Because substantially longer $3 / 8$-in. tubing was used between the splitters and the mass flowmeters than was used during the sample probe tests, the mass flowmeters were checked in-place, using the calibrated mass flowmeter, to obtain correct flow rate settings (each of the three outlet legs were sampled at $56.6 \mathrm{~L} / \mathrm{min}$ ).

Splitter tests were typically performed by obtaining three sequential sets of filters (each sample set was $5.00 \pm 0.05 \mathrm{~min}$ for a per-outlet leg sample volume of $283 \mathrm{~L}$ ) to measure split ratios and rinsing the interior surfaces with methanol to measure internal losses. The $4.1-\mathrm{cm}$-long connector between the splitters was rinsed along with splitter 1 . Six splitter tests were performed with $5.5,10.8,13.5$, and $16.3 \mu \mathrm{m}$ AED particles (target sizes were $5,10,12.5$, and $15 \mu \mathrm{m}$; deviations were caused by a larger than nominal vibrating orifice size); both the $10.8 \mu \mathrm{m}$ and the $16.3 \mu \mathrm{m}$ tests were replicated, each on separate days. No tests were performed with $1-\mu \mathrm{m}$ particles (although such tests had been planned) 
because the test with $5.5-\mu \mathrm{m}$ particles showed both splitters to have essentially ideal performance and, consequently, tests at smaller particle sizes would have yielded similar results. Instead, tests were performed with $13.5-\mu \mathrm{m}$ particles to provide additional information on split ratios versus particle size. One of the 10.8- $\mu \mathrm{m}$ tests (Test P25) was extended to a total of seven samples, with the last four samples consisting of pairs of replicated samples with alternate mass flowmeter connections, to provide a check of mass flowmeter precision. Sample flow rate uncertainty was estimated to be $\pm 5 \%$ based on the calibration check of the mass flowmeters. Other than that single test, the same mass flowmeter was always connected to the same outlet leg filter housing. The splitters were cleaned and dried between each test.

\subsection{Sample Analysis}

Samples were analyzed fluoroscopically to determine the relative number of particles collected on internal probe surfaces and on filters. The interior surfaces of the nozzles and probes were rinsed two or three times with 20 - to $30-\mathrm{mL}$ aliquots of methanol to remove deposited particles. This method indicated that nearly all of the particles were removed on the first rinse. In the case of filters, $20 \mathrm{~mL}$ of methanol was added to the filter in a beaker, and the filters were gently agitated for a few seconds. The fluorescence of the resulting methanol solution was then measured on a fluorometer typically between 15 and $60 \mathrm{~min}$ after the methanol was added. Because the filter media caused a measurable background fluorescence, two blank filters were included with every batch of filters from the probe tests. The total quantity of particulate matter on the filters, in units of fluorescence, was then determined by correcting the average of three.readings by the average quantity of fluorescence in the two blank filter solutions. Fluorometer scale factors of $1 \mathrm{X}, 10 \mathrm{X}$, and $50 \mathrm{X}$ were used to increase the range of the instrument and were included in determining the quantity of particulate matter in the samples. No correction was necessary or applied to the rinses of the internal nozzle and probe surfaces; however, the fluorometer was zeroed using blank methanol before analyzing all samples. The fluorometer zero was confirmed periodically during each batch of samples.

Test data were analyzed using a templated worksheet to obtain information on the efficiency of each probe to transfer particles to the collection filter. As shown in Appendix A, these worksheets allowed determination of particle size, wind speed, probe type and position, sample flow rate, isokinetic ratio, internal losses, collection filter efficiency, and overall probe efficiency for each subtest. In performing the calculations, the ratio of particle concentrations at each probe location was determined from data obtained before and after each set of probe subtests. The ratio was used to correct the results for slight nonuniformity of particle concentrations in the wind tunnel test section. For tests through P09 (during which the additional IRN data were not obtained), this correction was based on averaged data from subsequent tests.

\subsection{Precision (Repeatability)}

The precision (repeatability) was determined for the results of wind tunnel tests of air sampling probes. The repeatability of the results was determined as the average and range of differences between results of similar tests and subtests. 
A number of tests were repeated to test the precision of test results. . Additionally, subtests within each test also provided information on precision. Repeatability comparisons were based on filter measurements from similar tests and subtests. Using 35 comparable sets of data from tests 05 through 23 , the average test-to-test repeatability was $\pm 13 \%$; six of the 35 comparisons exceeded $20 \%$. Using 102 comparable sets of data from subtests, the same-test repeatability averaged $\pm 6 \%$; four of the 102 comparisons exceeded $20 \%$.

\subsection{Accuracy (Uncertainty)}

The accuracy (uncertainty) was determined for the results of wind tunnel tests of air sampling probes. The uncertainty associated with the results was estimated by performing an assessment of known, potentially significant sources of error in tests and analyses. The uncertainty of two components of the test results were estimated, that of concentration, $C$, and concentration ratio, CR, to fully understand the accuracy of the data. The concentration ratio was defined as the ratio of the actual concentration of particles in the wind tunnel to the concentration determined from a filter positioned immediately downstream of a sample probe. The difference between the actual concentration and that determined by a filter was equal to the sum of the probe aspiration efficiency and the probe transmission efficiency, which were in turn influenced by particle size, air speed, sample flow rate, nozzle configuration, and probe geometry.

The uncertainty in the concentration measurement was determined as the square root of the summation of the squares of the partial derivatives of the concentration equation with respect to each variable, as described by Holman and Gajda (1978). Particle concentration, C, was calculated using Equation (1) and the uncertainty in concentration, $W_{C}$, was determined from Equation (2) that reduces to form Equation (3).

$$
\begin{gathered}
\mathrm{C}=\mathrm{M} \mathrm{Q}^{-1} \mathrm{t}^{-1} \\
\mathrm{~W}_{\mathrm{C}}=\left[\left(\delta \mathrm{C} / \delta \mathrm{M} \mathrm{W}_{\mathrm{M}}\right)^{2}+\left(\delta \mathrm{C} / \delta \mathrm{Q}_{\mathrm{Q}}\right)^{2}+\left(\delta \mathrm{C} / \delta \mathrm{t} \mathrm{W}_{\mathrm{v}}\right)^{2}\right]^{1 / 2} \\
\mathrm{~W}_{\mathrm{C}}=\left[\left(\mathrm{W}_{\mathrm{M}} / \mathrm{Qt}\right)^{2}+\left(-\mathrm{MW}_{\mathrm{Q}} / \mathrm{Q}^{2} \mathrm{t}\right)^{2}+\left(-\mathrm{MW}_{\mathrm{t}} / \mathrm{Qt}^{2}\right)^{2}\right]^{1 / 2}
\end{gathered}
$$

where: $\quad M=$ mass or quantity of collected particles

$Q=$ sample flow rate

$t=$ sample duration

$W_{n}=$ uncertainty in determination of variable " $n$ ".

Following the method for determining uncertainty in particle concentration, the uncertainty in the measured concentration ratio, $\mathrm{W}_{\mathrm{CR}}$, was determined. The concentration ratio, $\mathrm{CR}$, was calculated using Equation (4) and the uncertainty in concentration, $W_{C R}$, was determined from Equation (5) that reduces to form Equation (6).

$$
\begin{gathered}
C R=C_{F} C_{R}^{-1} D^{-1} \\
W_{C R}=\left[\left(\delta C R / \delta C_{F} W_{C F}\right)^{2}+\left(\delta C R / C_{R} W_{C R}\right)^{2}+\left(\delta C R / \delta D F W_{D F}\right)^{2}\right]^{1 / 2}
\end{gathered}
$$




$$
\left.\mathrm{W}_{\mathrm{CR}}=\left[\left(\mathrm{W}_{\mathrm{CF}} / \mathrm{C}_{\mathrm{R}} \mathrm{DF}\right)^{2}+\left(-\mathrm{C}_{\mathrm{F}} \mathrm{W}_{\mathrm{CR}} / \mathrm{C}_{\mathrm{R}}{ }^{2} \mathrm{DF}\right)^{2}+\left(-\mathrm{C}_{\mathrm{F}} \mathrm{W}_{\mathrm{DF}} / \mathrm{C}_{\mathrm{R}} \mathrm{DF}\right)^{2}\right)^{2}\right]^{1 / 2}
$$

where: $\quad C_{F}=$ particle concentration determined from the filter downstream of a sample probe

$C_{R}=$ actual particle concentration from the isokinetic reference nozzle

$\mathrm{DF}=$ ratio of concentration at the sample probe to that at the reference probe (based on sequential measurements using multiple isokinetic reference probes).

To determine the uncertainty in test results, the uncertainty of measured variables was estimated. This was done by estimating uncertainties that were potentially significant to the result. Other potential uncertainties, such as those caused by minor variations in mean wind speed on the aspiration efficiency of isokinetic nozzles or the presence of relatively small concentrations of doublet particles (an artifact of the vibrating orifice aerosol generator), were considered but were estimated to have negligible effect on the overall result. The uncertainty in mass or quantity of collected particles, $\mathrm{W}_{\mathrm{M}}$ in fluorescence units, was estimated to be $0.19+0.024(\mathrm{M})$. This result was determined based on factors influencing the measurement of fluorescence from collected particles and included the average uncertainty in blank solution correction and the uncertainty in the volumetric addition of methanol to rinse collected particles from filters. The uncertainty in mass or quantity of collected particles increased with increasing mass or quantity of particles in the sample largely because of the uncertainty in the volumetric addition of methanol. Because of the uncertainty in blank correction, however, the relative impact of the uncertainty in the particle's mass or quantity was greatest for samples containing the smallest quantities of particles. The uncertainty in sample flow rate, $W_{Q}$ in $L / m i n$, was estimated to be $17-0.11(Q)$. This result was based on the nominal accuracy of the mass flowmeters and the deviation of measured data from the "best-fit" calibration equations generated from calibration data based on National Institute of Standards and Technology-traceable standards. The uncertainty in sample flow rate decreased with increasing flow rate over the nominal range of the mass flowmeters. The uncertainty in the 10 min sample duration, $\mathrm{W}_{\imath}$, was $3 \mathrm{~s}(0.5 \%)$.

Data and results from tests 11 through 17,22 , and 23 were evaluated to determine estimated measurement uncertainties. The selected tests were chosen for the uncertainty evaluation because they all included results from collocated and simultaneous measurements using the reference and sample probes and thus provided detailed information on the differences.in particle concentration between the various probe locations. The selected tests are thought to have been representative of all of the tests performed. From the tests, 40 discrete uncertainty results were calculated. The relative uncertainty; which is the ratio of the uncertainty in concentration to particle concentration, averaged $12 \% \pm 1 \%$ and ranged from $8 \%$ to $16 \%$.

Using the same 40 data sets, the ratio of the uncertainty in the measured concentration ratio to the concentration ratio averaged $16 \% \pm 2 \%$ and ranged from $12 \%$ to $23 \%$. Because of a tendency for the greatest uncertainties to be present during tests performed at the largest particle size and fastest air speed $(15 \mu \mathrm{m}$ and $15 \mathrm{~m} / \mathrm{s})$, the uncertainty data were re-evaluated by groups; the average uncertainty in the measured concentration ratio to the concentration ratio was $22 \% \pm 2 \%$ for the two tests performed at $15 \mu \mathrm{m}$ and $15 \mathrm{~m} / \mathrm{s}$, and was again found to average $16 \% \pm 2 \%$ for all other tests.

Average relative test-to-test repeatability.was comparable to the estimated relative test uncertainty, based on particle concentrations derived from the filter data. In contrast, average relative same-test repeatability was less than estimated relative test uncertainty. In both cases, however, the repeatability 
results varied over a greater range than did the estimated uncertainties. This result indicates that unidentified variables which were not controlled from test to test may have added measurable but unidentified elements of uncertainty to the results.

\subsection{Results}

\subsection{Probe Tests}

Figures 10 and 11 show the resulting concentration ratios, measured at the collection filters, as a function of particle size for the probes at 5 and $15 \mathrm{~m} / \mathrm{s}$, respectively. Third-order polynomial fitted lines are shown only to clarify the trends for each probe. The particle diameters shown are AED or the diameter of a spherical water droplet that has the same settling velocity in quiescent air as the actual particle. The most desirable result for a probe would be a flat line at $100 \%$, indicating quantitative aerosol delivery to the filter.

The shrouded probes, when used within their design velocity ranges, had the most favorable results: probe $C$ at $5 \mathrm{~m} / \mathrm{s}$ and probe $D$ at $15 \mathrm{~m} / \mathrm{s}$. The concentration ratios at the filter were nearly flat from 1 to $10 \mu \mathrm{m}$ particle diameters. At $15 \mathrm{~m} / \mathrm{s}$, probe $\mathrm{C}$ (well outside of its design range) exhibited erratic results but always higher than $100 \%$. At $5 \mathrm{~m} / \mathrm{s}$, probe $\mathrm{D}$ (somewhat below its design range) exhibited steadily declining concentration ratios with increasing particle size. At both air velocities, the single nozzle isokinetic probe $F$ exhibited generally declining results with increasing particle size and had a concentration ratio greater than $90 \%$ only for particles smaller than around $5 \mu \mathrm{m}$ AED. The subisokinetic probe $\mathrm{E}$ exhibited concentration ratios above $90 \%$ out to 8 - or $10-\mu \mathrm{m}$ AED particles. At $5 \mathrm{~m} / \mathrm{s}$, the dual nozzle isokinetic probes, $A$ and $B$, performed similarly to each other and were bracketed by the single nozzle isokinetic and subisokinetic probes $E$ and $F$. At $15 \mathrm{~m} / \mathrm{s}$, the shrouded dual nozzle probe A slightly outperformed the unshrouded dual nozzle probe below about $10 \mu \mathrm{m}$.

Figure 12 shows the results for $10-\mu \mathrm{m}$ aerosol as a function of air velocity. This was the only particle size for. which the response versus velocity was investigated in detail. Probe $D$ at its fixed design flow rate showed excellent concentration ratio characteristics at $15 \mathrm{~m} / \mathrm{s}$, see Figure 4, but not at a lower velocity. Instead, probe D operating in the proportional flow rate mode showed a favorable flat response over the entire velocity range. On the other hand, probe $\mathbf{C}$ exhibited erratic results in proportional-flow mode when compared to fixed-flow mode. In fixed-flow mode, probe $C$ results were always greater than $100 \%$. Probes $\mathrm{E}$ and $\mathrm{F}$ exhibited variable results as a function of velocity; however, probe $\mathrm{E}$ showed concentration ratios nearly $30 \%$ higher compared to the isokinetic probe $\mathrm{F}$ because probe $\mathrm{E}$ was operated subisokinetically. The dual nozzle probes $\mathrm{A}$ and $\mathrm{B}$ performed alike with results bracketed by the two single nozzle probes.

Line-loss, as a percentage of the sum of probe deposition and filter collection, is plotted in Figures 13 and 14 for the $5-\mathrm{m} / \mathrm{s}$ and $15-\mathrm{m} / \mathrm{s}$ tests. The line-loss was only significant for particles larger than $10 \mu \mathrm{m}$ and was considerably more significant at the higher velocity. Further analysis will be needed to determine if the deposition occurred throughout the probe or was mostly in the nozzle. 


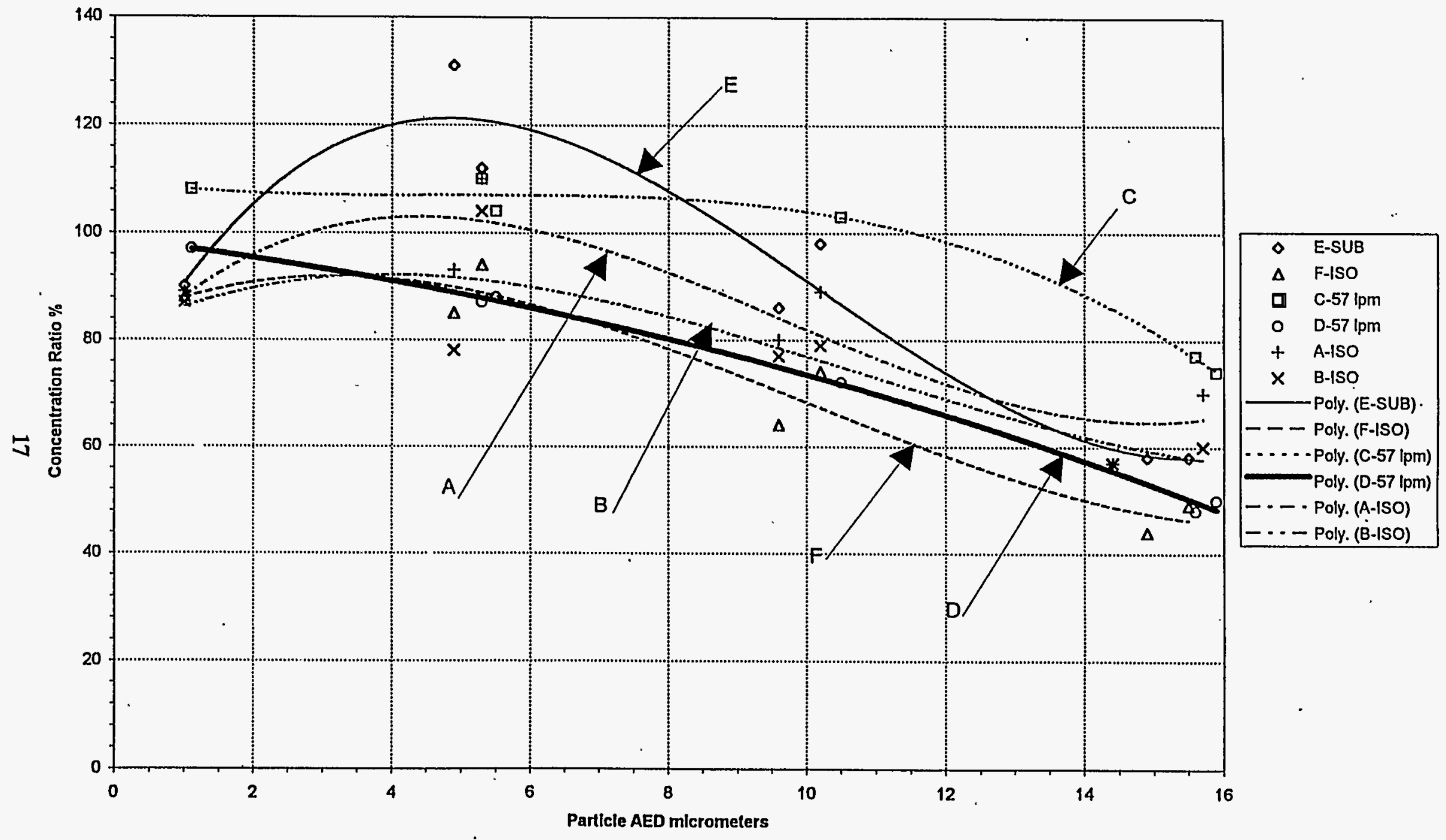

Figure 10. Concentration Ratio at Filter vs. Particle Size at $5 \mathrm{~m} / \mathrm{s}$ Air Velocity 


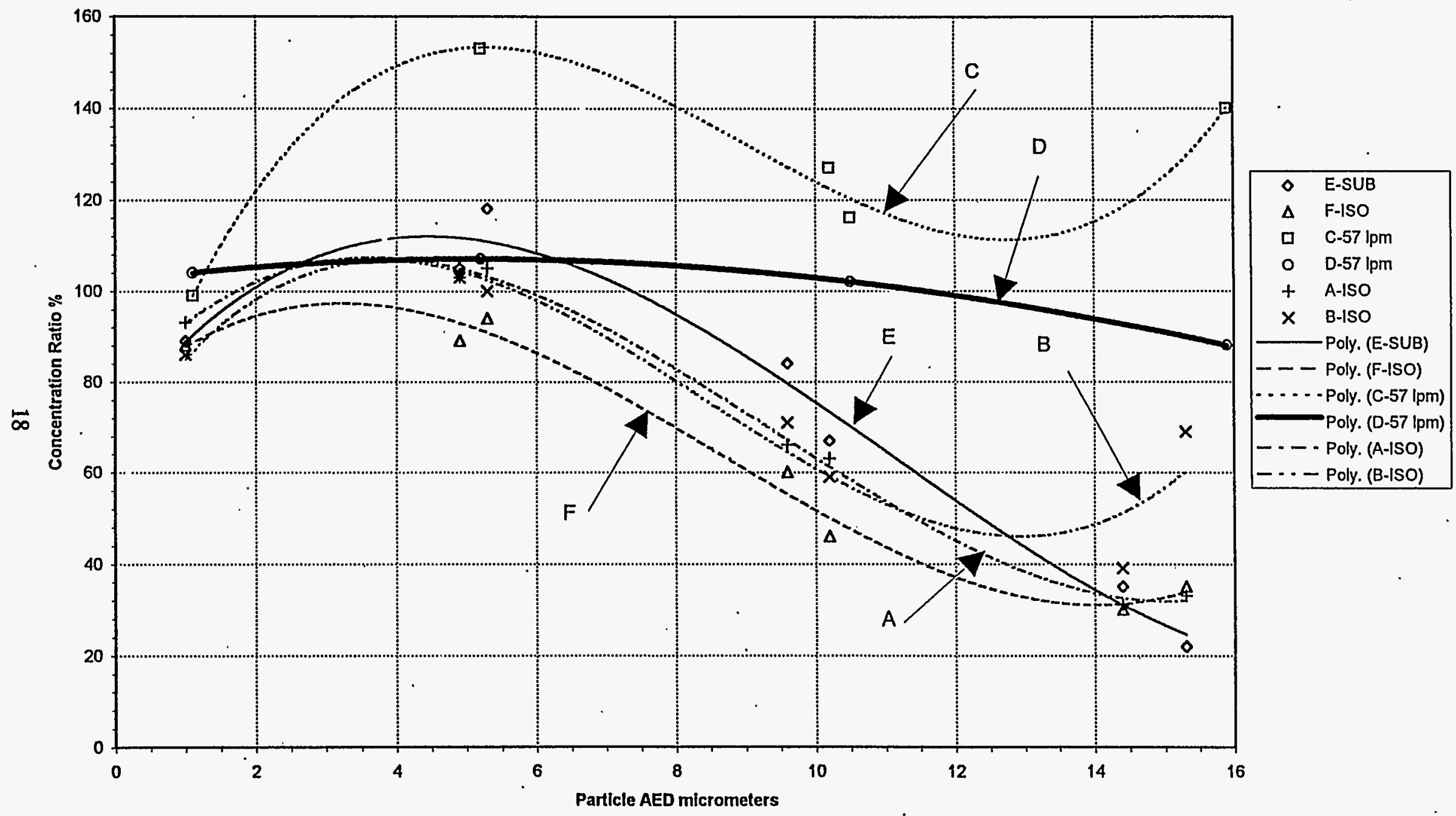

Figure 11. Concentration Ratio at Filter vs. Particle Size at $15 \mathrm{~m} / \mathrm{s}$ Air Velocity 


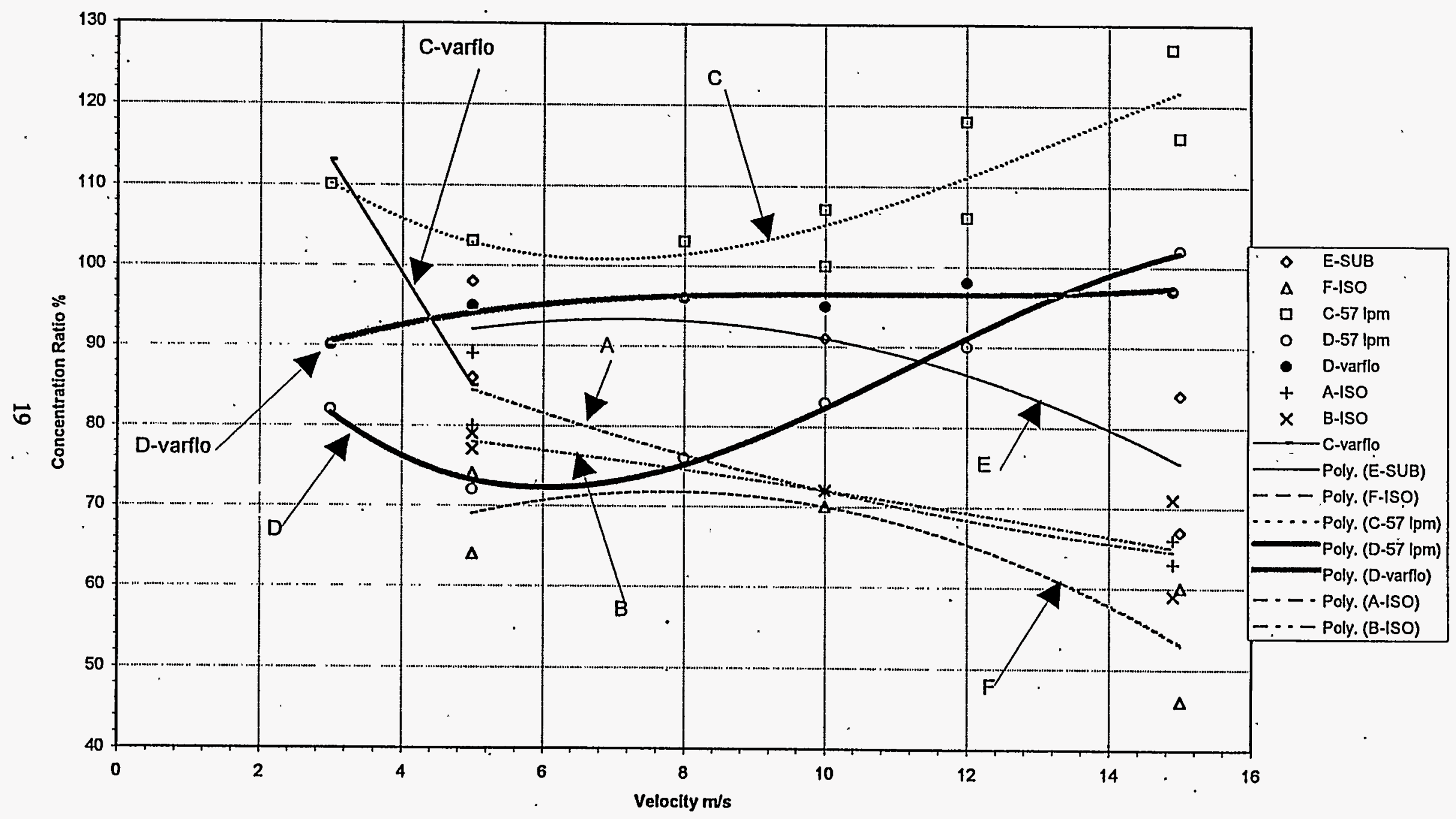

Figure 12. Concentration Ratio at Filter for $10-\mu \mathrm{m}$ Particles as a Function of Air Velocity 


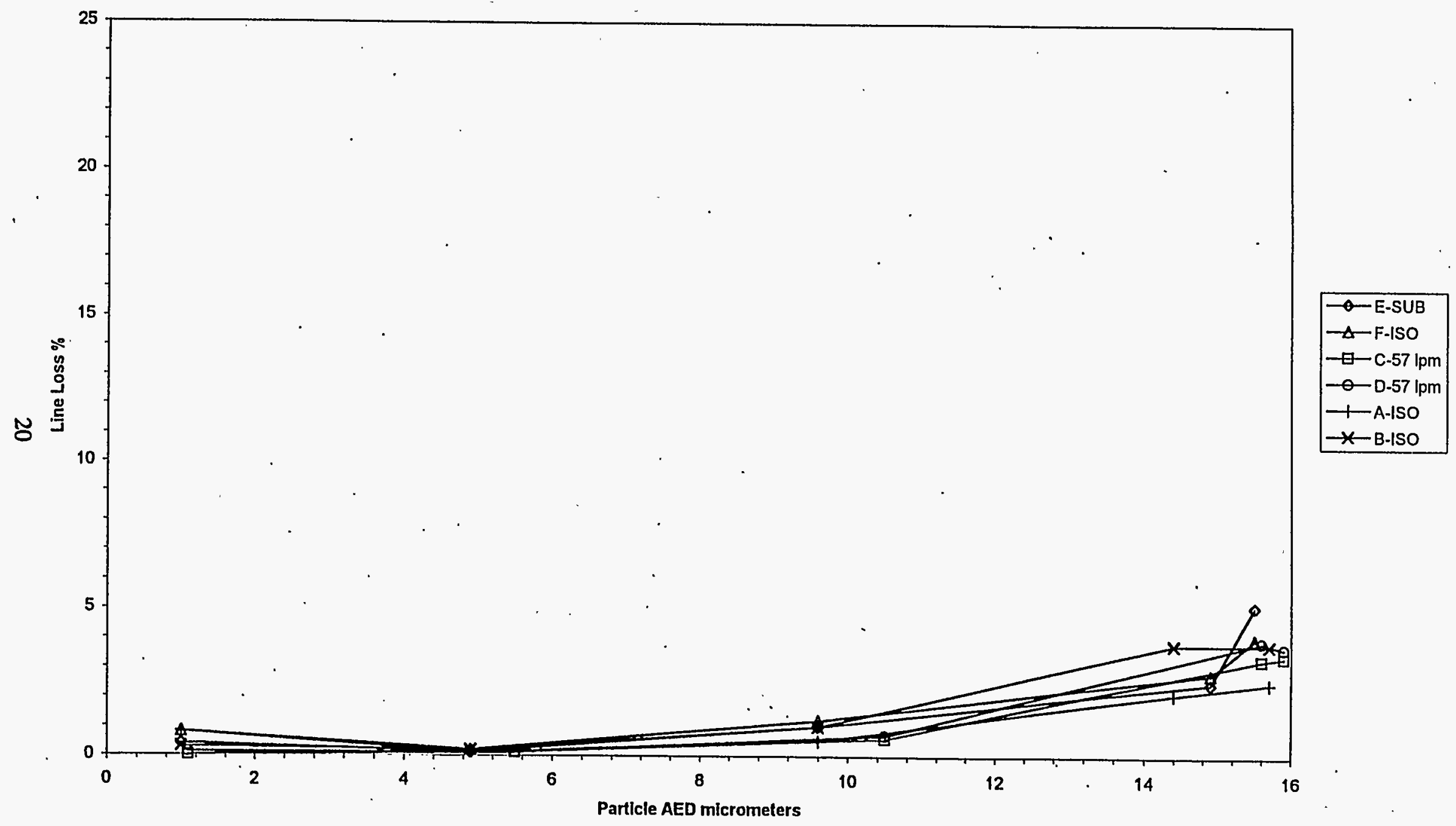

Figure 13. Line-Loss at $5 \mathrm{~m} / \mathrm{s}$ Air Velocity 


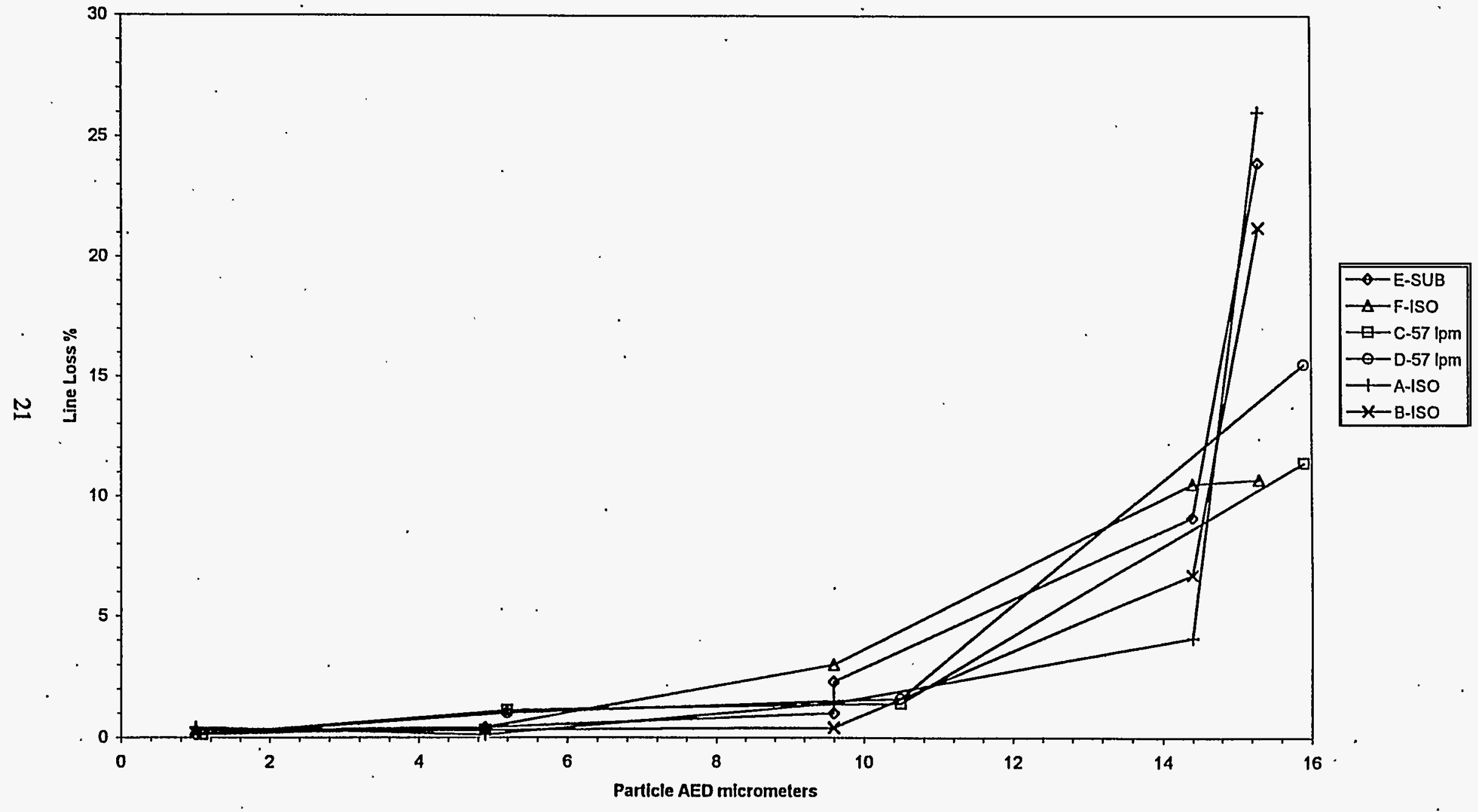

Figure 14. Line-Loss at $15 \mathrm{~m} / \mathrm{s}$ Air Velocity 
Except where the line-loss was significant, the concentration ratio measured at the filter and plotted in Figures 10 through 12 is essentially equal to the aspiration ratio. The aspiration ratio is the ratio of the concentration of particles in the opening of the nozzle to the concentration in the approaching free stream. The average aspiration ratios are listed in Appendix A as the average probe efficiency values, which were calculated using the combined particle collection on the filter and in the probe. The probe efficiency and filter efficiency values were nearly the same except for $15-\mu \mathrm{m}$-diameter particles. The bias shown in Figures 10 through 12 from the ideal concentration ratio of 1 is probably the result of aspiration problems. Poor aspiration can result from the nozzle design, turbulence, or nonisokinetic conditions. Additional tests with other isokinetic nozzle designs may result in better performance for probes having traditional isokinetic nozzles than those tested here.

\subsection{Splitter Tests}

The data from the splitter tests are summarized in Table 4. The detailed test worksheets are included in Appendix A. Each row in Table 4 represents the results from a subtest. There are two columns of "split" data, one for each splitter. The split ratio is the ratio of the particle mass at outlet "a" to the total particle mass at outlets "a" plus "b." The percentage reaching the other outlet port of the same splitter is then 100 minus the value in the table. The last two columns of the table list the percentage of total particle mass entering each splitter that was deposited in the splitter's interior. A comparison of the results from the repeated tests shows that they were highly repeatable.

Figure 15 shows the "split" data for both splitters as a function of particle size. The data in the bottom half of the figure are for splitter 1 , and the upper plot is for splitter 2 . The horizontal lines in the plots represent the ideal performance for each splitter. The plots show that for particles larger than about $10 \mu \mathrm{m}$ the particle concentration in one leg of the splitter becomes enriched while it is depleted in the other leg. In splitter 1, the particle mass and concentration in the larger leg, outlet A, was enriched by $20 \%$. In splitter 2 , outlet A was enriched by about $25 \%$.

Figure 16 shows the plotted internal loss data for each splitter. The internal losses in the splitters are very low when compared to that of the probes in Figure 14 and comparable to that of Figure 13.

\subsection{Conclusions}

The wind tunnel tests indicated that shrouded probes such as probes $\mathbf{C}$ and $\mathrm{D}$ can deliver samples with much less particle-size bias (over the range tested, up to $15 \mu \mathrm{m}$ AED) than the isokinetic nozzle probes tested. The use of the shrouded probe operated in proportional flow shows even lower sensitivity to particle size and velocity than the fixed-flow mode; however, further verification over a wider range of particle sizes would be beneficial. 
Table 4. Summarized Splitter Test Results

\begin{tabular}{|c|c|c|c|c|c|}
\hline \multirow[b]{2}{*}{ Test } & \multirow[b]{2}{*}{ Particle AED, $\mu \mathrm{m}$} & \multicolumn{2}{|c|}{ Split mass ratio outlet "a"/inlet } & \multicolumn{2}{|c|}{ Internal loss \% } \\
\hline & & Splitter 2 & Splitter 1 & Splitter 2 & $\begin{array}{c}\text { Splitter } \\
1\end{array}$ \\
\hline \multirow[t]{3}{*}{ P24 } & \multirow[t]{3}{*}{10.8} & 53 & 34 & 0.8 & 0.8 \\
\hline & & 54 & 35 & & \\
\hline & & 54 & 36 & & \\
\hline \multirow[t]{7}{*}{$\mathrm{P} 25$} & \multirow[t]{7}{*}{10.8} & 52 & 34 & 0.8 & 0.7 \\
\hline & & 52 & 34 & & \\
\hline & & 51 & 33 & & \\
\hline & & 51 & 33 & & \\
\hline & & 52 & 34 & & \\
\hline & & 52 & 36 & & \\
\hline & & 52 & 35 & & \\
\hline \multirow[t]{3}{*}{ P26 } & \multirow[t]{3}{*}{5.5} & 50 & 34 & 0.3 & 0.3 \\
\hline & & 49 & & & \\
\hline & & 48 & 34 & & \\
\hline \multirow[t]{3}{*}{ P27 } & \multirow[t]{3}{*}{16.2} & 62 & 25 & 1.8 & 2.0 \\
\hline & & 63 & 23 & & \\
\hline & & 64 & 27 & & \\
\hline \multirow[t]{3}{*}{ P28 } & \multirow[t]{3}{*}{16.4} & 61 & 29 & 1.8 & 2.0 \\
\hline & & 62 & 29 & & \\
\hline & & 62 & 28 & & \\
\hline \multirow[t]{3}{*}{ P29 } & \multirow[t]{3}{*}{13.5} & 56 & 32 & 1.3 & $\cdot 1.2$ \\
\hline & & 55 & 31 & . & \\
\hline & & 55 & 30 & & \\
\hline
\end{tabular}




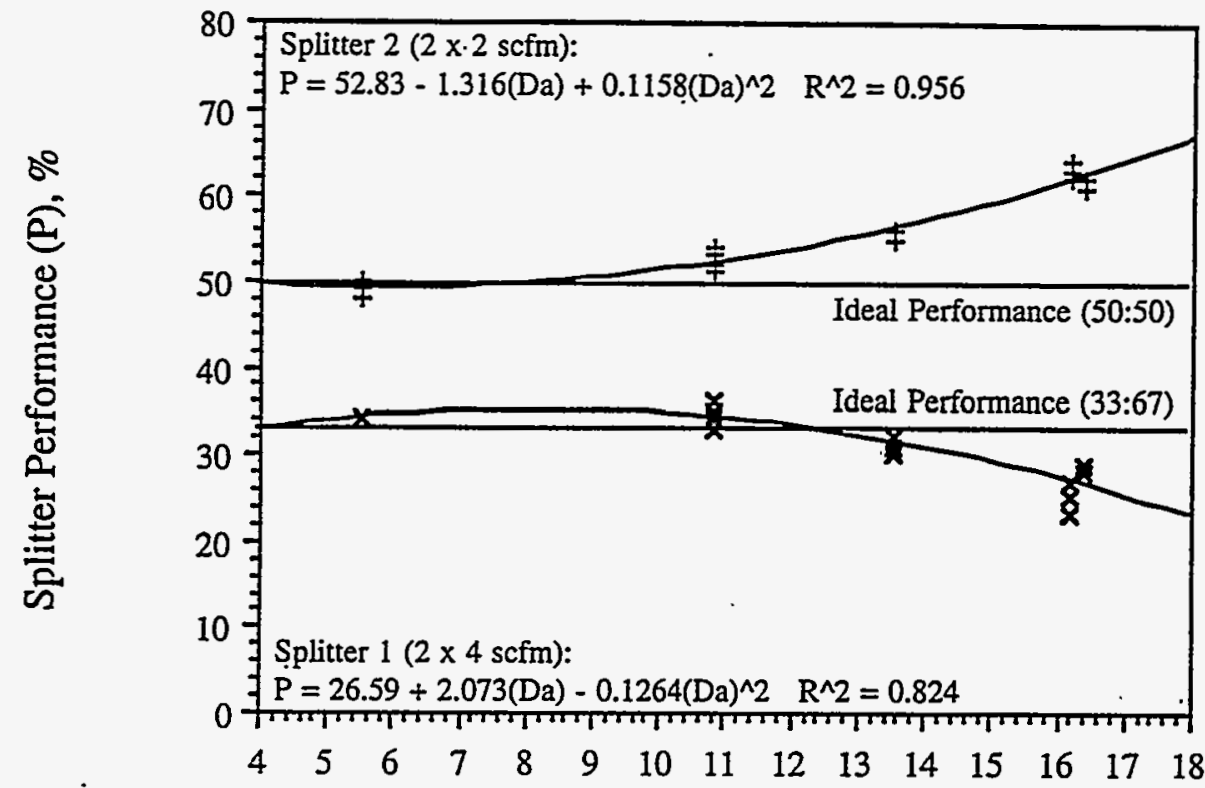

Splitter Tests

Raw/Preliminary Data

Tests 'P24-P28

43 of 44 Measurements

+ Splitter 2

× Splitter 1 .

Performance @ $15 \mu \mathrm{m}$ :

$2 \times 2: 118 \%$ of Ideal

$2 \times 4: \quad 89 \%$ of Ideal

Aerodynamic Particle Size (Da), $\mu \mathrm{m}$

Figure 15. Splitter Performance

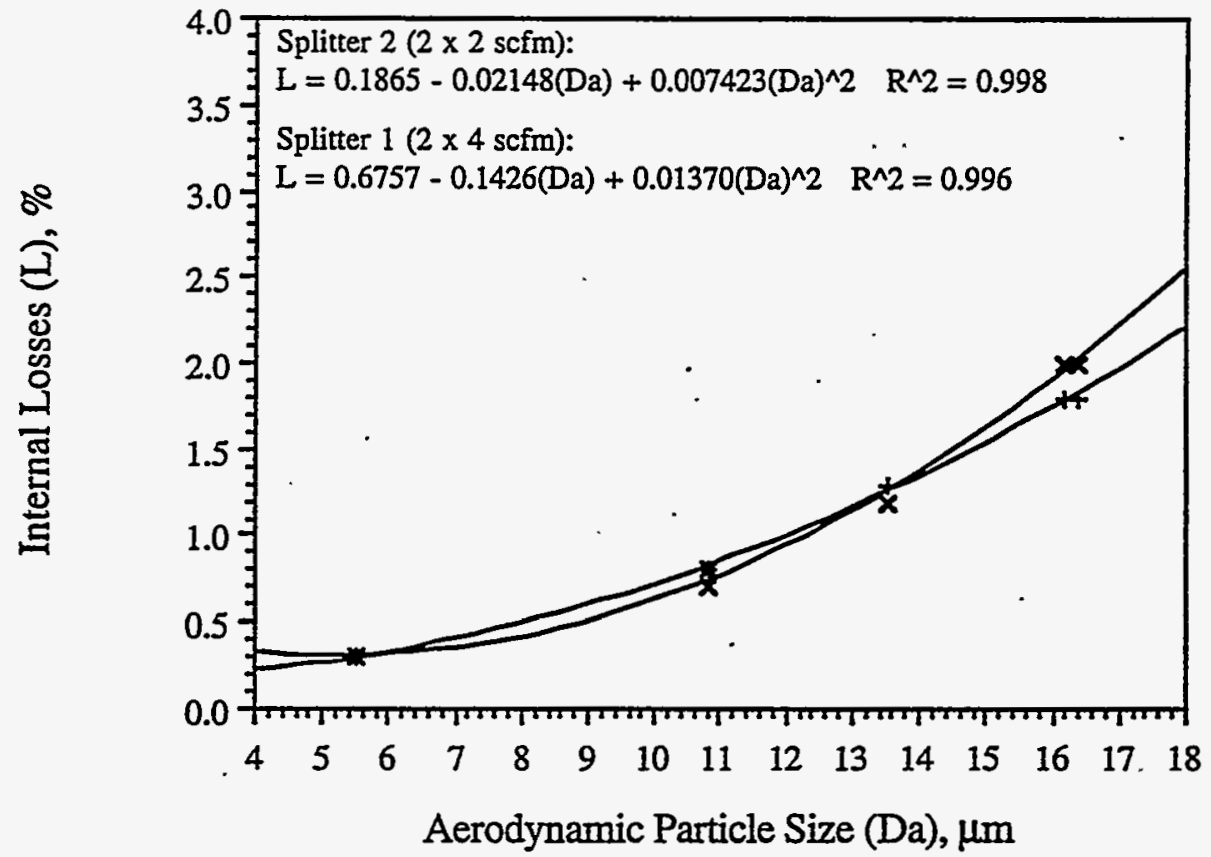

Splitter Tests

Raw/Preliminary Data

Tests P24-P28

+ Splitter 2

X Splitter 1

Figure 16. Splitter Internal Losses 
The functional requirements for Westinghouse Hanford Company air sampling systems (Glissmeyer et al. 1994) are that the

- total transport of $10-\mu \mathrm{m}$ AED particles be $>50 \%$ from the free stream to the collector/analyzer

- sampler probe inlet have aspiration ratios in the range of $80 \%$ to $150 \%$ for $10-\mu \mathrm{m}$ AED particles

- sampler probe inlet transport $80 \%$ to $130 \%$ of $10-\mu \mathrm{m}$ AED particles.

As shown in Figure 11, all of the tested probes satisfy the first requirement, probably because of the simplicity of the probe designs with very minimal transport line length. Because of the low lineloss as shown in Figures 12 and 13, the aspiration ratios are virtually the same as the concentration ratios shown in Figure 11. Consequently, only the shrouded probes $C$ and D, and the fixed-ratio subisokinetic probe $\mathrm{E}$ satisfied the second requirement over most of the test conditions. Because the deposition in the probe nozzles were not analyzed separately from the transport line, compliance with the third requirement was not tested. The selection of one of these probes depends on the air velocity range expected in the stack and whether a fixed sample flow rate (probes $C$ or $D$ ) or a velocityproportional sample flow rate (probes $\mathrm{E}$ or $\mathrm{D}$ in proportional mode) are desired.

The flow splitters exhibited very small $(\leq 2 \%)$ internal losses as a function of particle size. For particles smaller than about $10-\mu \mathrm{m}$ AED, the devices evenly split the sampled particles so that the concentration in the streams exiting the splitter are equal. As particle size increased, however, the concentration in the exit streams did become unequal. This effect is likely caused by aerodynamic focusing of the particles possessing relatively large inertia. This effect may be remedied by altering the angles of the outlets relative to the inlet. It is possible to investigate the effect of changing angles using modeling methods followed by prototype testing.

\subsection{References}

40 CFR 61, Subpart H, U.S. Environmental Protection Agency, "National Emission Standards for Emissions of Radionuclides Other than Radon from Department of Energy Facilities." Code of Federal Regulations.

American National Standards Institute (ANSI). 1982. Guide to Sampling Airborne Radioactive Materials in Nuclear Facilities. American National Standards Institute, New York (originally affirmed in 1969).

Glissmeyer, J. A., M. D. Hoover, G. C. Newton, J. L. Alvarez, A. R. McFarland, and J. C. Rodgers. 1994. Functional Requirements Document for Measuring Emissions of Airborne Radioactive Materials. PNL-10148, Pacific Northwest Laboratory, Richland, Washington.

Holman, J. P., and W. J. Gajda. 1978. Experimental Methods for Engineers. Third Edition. McGraw-Hill Book Company, New York. 
McFarland, A.R., C. A. Ortiz, M. E. Moore, R. E. DeOtte, Jr., and S. Somasundaram. 1989.

"A Shrouded Aerosol Sampling Probe." Environment, Science, and Technology 23:1487-1492.

Rockwell Hanford Operations (RHO). 1992a. Sample Flow Splitter Assembly. H-2-92503. Rockwell Hanford Operations, Richland, Washington.

Rockwell Hanford Operations (RHO). 1992b. Sample Flow Splitter Details. H-2-92504. Rockwell Hanford Operations, Richland, Washington.

Rodgers, J. C., C. I. Fairchild, G. O. Wood, C: A. Ortiz, A. Muyshondt, and A. R. McFarland. 1994. Single Point Aerosol Sampling: Evaluation of Mixing and Probe Performance in a Nuclear Stack. Aerosol Technology Laboratory Report 8405/12/94/ARM, Department of Mechanical Engineering, Texas A\&M University, College Station, Texas. 
Appendix A

Summary Test and Subtest Data Tables Arranged Numerically 



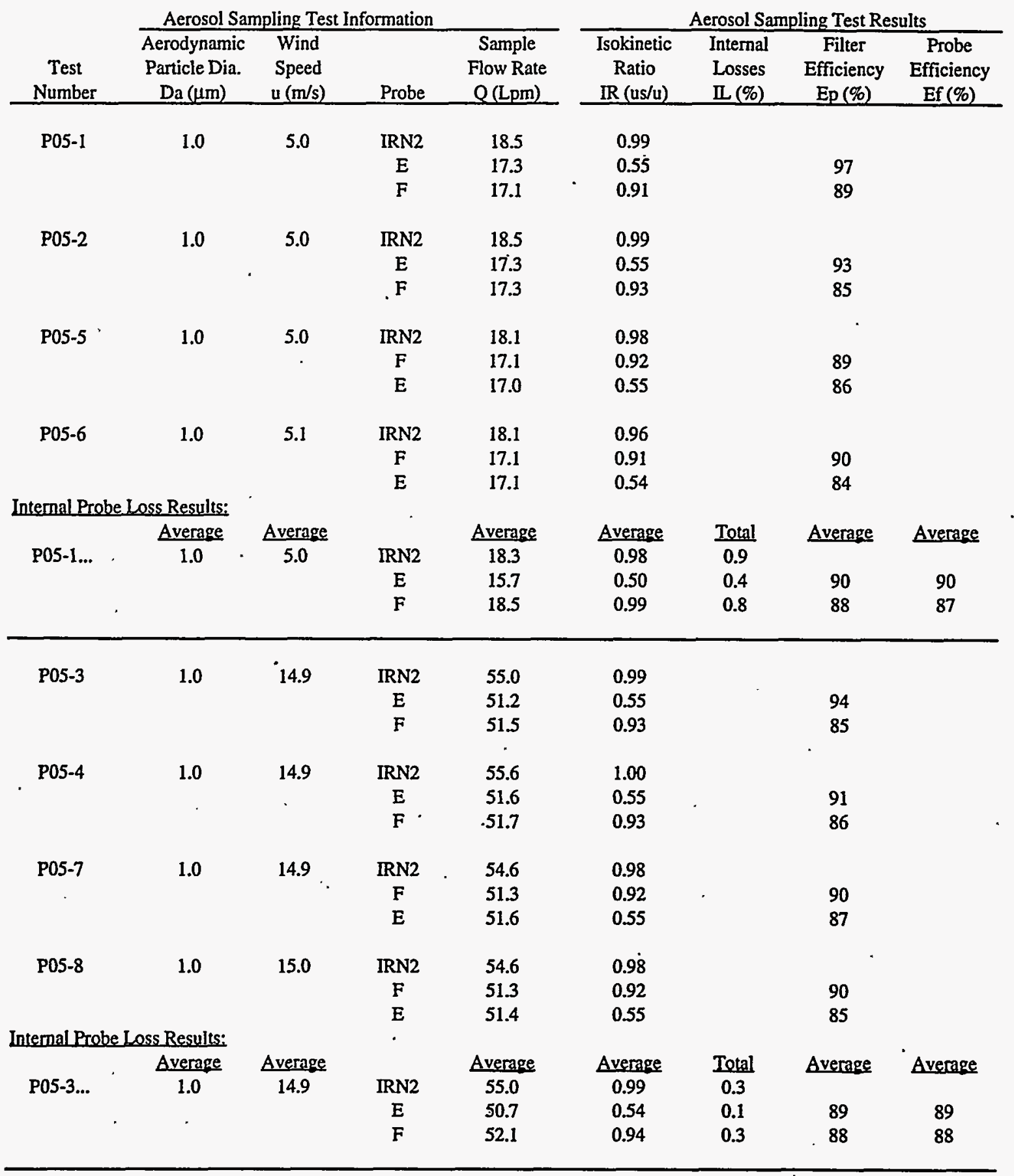




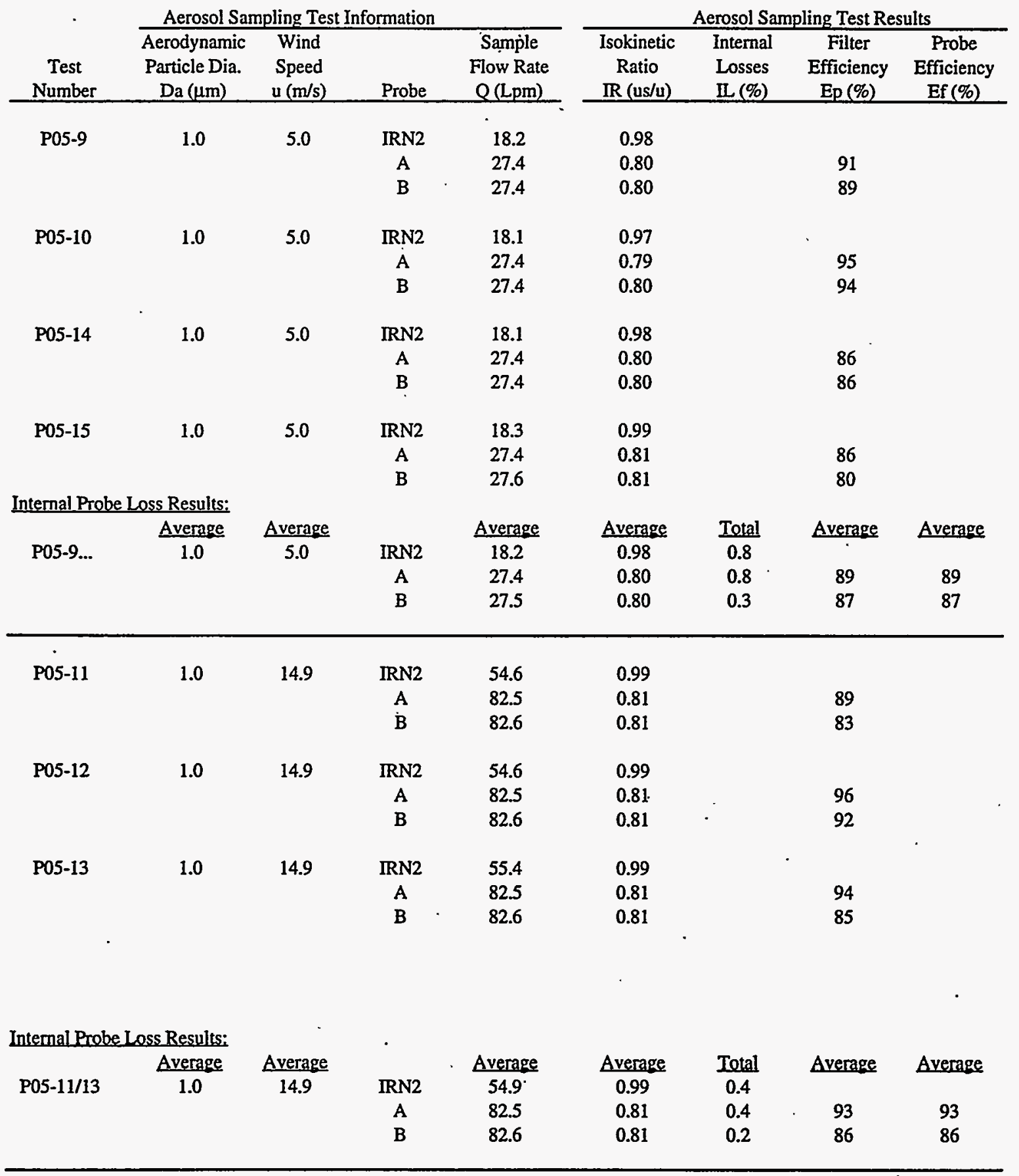




\begin{tabular}{|c|c|c|c|c|c|c|c|c|}
\hline \multirow[b]{2}{*}{$\begin{array}{c}\text { Test } \\
\text { Number }\end{array}$} & \multicolumn{4}{|c|}{ Aerosol Sampling Test Information } & \multicolumn{4}{|c|}{ Aerosol Sampling Test Results } \\
\hline & $\begin{array}{c}\text { Aerodynamic } \\
\text { Particle Dia. } \\
\mathrm{Da}(\mu \mathrm{m})\end{array}$ & $\begin{array}{c}\text { Wind } \\
\text { Speed } \\
\mathrm{u}(\mathrm{m} / \mathrm{s}) \\
\end{array}$ & Probe & $\begin{array}{c}\text { Sample } \\
\text { Flow Rate } \\
\mathrm{Q}(\mathrm{Lpm})\end{array}$ & $\begin{array}{c}\text { Isokinetic } \\
\text { Ratio } \\
\operatorname{IR}(\mathrm{us} / \mathrm{u}) \\
\end{array}$ & $\begin{array}{l}\text { Intemal } \\
\text { Losses } \\
\text { lL (\%) } \\
\end{array}$ & $\begin{array}{c}\text { Filter } \\
\text { Efficiency } \\
\text { Ep }(\%) \\
\end{array}$ & $\begin{array}{c}\text { Probe } \\
\text { Efficiency } \\
\text { Ef (\%) }\end{array}$ \\
\hline P06-1 & 9.6 & 5.0 & $\begin{array}{l}\text { IRN2 } \\
\text { E } \\
\text { F }\end{array}$ & $\begin{array}{l}18.5 \\
17.3 \\
17.1\end{array}$ & $\begin{array}{l}1.00 \\
0.55 \\
0.92\end{array}$ & & $\begin{array}{l}81 \\
63\end{array}$ & \\
\hline $\mathrm{P} 06-2$ & 9.6 & 5.0 & $\begin{array}{l}\text { IRN2 } \\
\text { E } \\
\text { F }\end{array}$ & $\begin{array}{l}18.5 \\
17.3 \\
17.3\end{array}$ & $\begin{array}{l}1.00 \\
0.56 \\
0.93\end{array}$ & 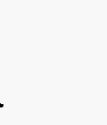 & $\begin{array}{l}89 \\
69\end{array}$ & \\
\hline P06-3 & 9.6 & 5.1 & $\begin{array}{l}\text { IRN2 } \\
\text { E } \\
\text { F }\end{array}$ & $\begin{array}{l}18.5 \\
17.1 \\
17.3\end{array}$ & $\begin{array}{l}0.98 \\
0.54 \\
0.92\end{array}$ & & $\begin{array}{l}87 \\
60\end{array}$ & \\
\hline $\begin{array}{r}\text { Insermal Prs } \\
\text { P06-1/3 }\end{array}$ & $\frac{\text { Oss Results: }}{\frac{\text { Average }}{9.6}}$ & $\frac{\text { Average }}{5.0}$ & $\begin{array}{c}\text { IRN2 } \\
E \\
F\end{array}$ & $\begin{array}{c}\text { Average } \\
18.5 \\
17.2 \\
17.3\end{array}$ & $\begin{array}{c}\text { Average } \\
0.99 \\
0.55 \\
0.92\end{array}$ & $\begin{array}{l}\text { Total } \\
0.2 \\
1.0 \\
1.2\end{array}$ & $\begin{array}{c}\text { Average } \\
86 \\
64\end{array}$ & $\begin{array}{c}\text { Average } \\
85 \\
63\end{array}$ \\
\hline P06-4 & 9.6 & 5.0 & $\begin{array}{c}\text { IRN2 } \\
\text { A } \\
\text { B }\end{array}$ & $\begin{array}{l}18.5 \\
27.4 \\
27.4\end{array}$ & $\begin{array}{l}0.99 \\
0.79 \\
0.79\end{array}$ & & $\begin{array}{l}78 \\
77\end{array}$ & \\
\hline P06-5 & 9.6 & 5.0 & $\begin{array}{c}\text { IRN2 } \\
\text { A } \\
\text { B }\end{array}$ & $\begin{array}{l}18.5 \\
27.4 \\
27.4\end{array}$ & $\begin{array}{l}0.99 \\
0.80 \\
0.80\end{array}$ & & $\begin{array}{l}82 \\
79\end{array}$ & \\
\hline P06-6 & 9.6 & 5.0 & $\begin{array}{l}\text { IRN2 } \\
\text { A } \\
\text { B }\end{array}$ & $\begin{array}{l}18.4 \\
27.4 \\
27.4\end{array}$ & $\begin{array}{l}0.99 \\
0.80 \\
0.80\end{array}$ & & $\begin{array}{l}80 \\
74\end{array}$ & \\
\hline Internal Pro & oss Results: & & & & & & & \\
\hline $\mathrm{P} 06-4 / 6$ & $\begin{array}{c}\text { Average } \\
9.6\end{array}$ & $\frac{\text { Average }}{5.0}$ & $\begin{array}{c}\text { IRN2 } \\
\text { A } \\
\text { B }\end{array}$ & $\begin{array}{c}\text { Average } \\
18.5 \\
27.4 \\
27.4\end{array}$ & $\begin{array}{c}\text { Average } \\
0.99 \\
0.80 \\
0.80\end{array}$ & $\begin{array}{c}\text { Total } \\
0.6 \\
0.5 \\
1.0\end{array}$ & $\begin{array}{c}\text { Average } \\
80 \\
77\end{array}$ & $\begin{array}{c}\text { Average } \\
80 \\
76\end{array}$ \\
\hline
\end{tabular}




\begin{tabular}{|c|c|c|c|c|c|c|c|c|}
\hline \multirow[b]{2}{*}{$\begin{array}{c}\text { Test } \\
\text { Number }\end{array}$} & \multicolumn{4}{|c|}{ Aerosol Sampling Test Information } & \multicolumn{4}{|c|}{ Aerosol Sampling Test Results } \\
\hline & $\begin{array}{c}\text { Aerodynamic } \\
\text { Particle Dia. } \\
\text { Da }(\mu \mathrm{m})\end{array}$ & $\begin{array}{c}\text { Wind } \\
\text { Speed } \\
\mathrm{u}(\mathrm{m} / \mathrm{s})\end{array}$ & Probe & $\begin{array}{c}\text { Sample } \\
\text { Flow Rate } \\
\mathrm{Q}(\mathrm{Lpm})\end{array}$ & $\begin{array}{c}\text { Isokinetic } \\
\text { Ratio } \\
\text { IR (us/u) } \\
\end{array}$ & $\begin{array}{l}\text { Internal } \\
\text { Losses } \\
\text { IL }(\%) \\
\end{array}$ & $\begin{array}{c}\text { Filter } \\
\text { Efficiency } \\
\text { Ep (\%) }\end{array}$ & $\begin{array}{c}\text { Probe } \\
\text { Efficiency } \\
\text { Ef (\%) }\end{array}$ \\
\hline P06-7 & 9.6 & 15.2 & $\begin{array}{l}\text { IRN2 } \\
\text { E } \\
F\end{array}$ & $\begin{array}{l}54.6 \\
51.5 \\
50.9\end{array}$ & $\begin{array}{l}0.97 \\
0.54 \\
0.90\end{array}$ & & $\begin{array}{l}85 \\
58\end{array}$ & \\
\hline P06-8 & 9.6 & 15.0 & $\begin{array}{c}\text { IRN2 } \\
\text { E } \\
\text { F }\end{array}$ & $\begin{array}{l}54.6 \\
51.5 \\
50.9\end{array}$ & $\begin{array}{l}0.98 \\
0.55 \\
0.91\end{array}$ & & $\begin{array}{l}85 \\
65\end{array}$ & \\
\hline P06-9 & 9.6 & 15.0 & $\begin{array}{c}\text { IRN2 } \\
\text { E } \\
\text { F }\end{array}$ & $\begin{array}{l}54.1 \\
51.0 \\
51.5\end{array}$ & $\begin{array}{l}0.97 \\
0.55 \\
0.92\end{array}$ & & $\begin{array}{l}82 \\
57\end{array}$ & \\
\hline Internal Prob & oss Results: & & & & & & & \\
\hline P06-7/9 & $\frac{\text { Average }}{9.6}$ & $\frac{\text { Average }}{15.0}$ & $\begin{array}{l}\text { IRN2 } \\
\text { E } \\
\text { F }\end{array}$ & $\begin{array}{c}\text { Average } \\
54.5 \\
51.3 \\
51.1\end{array}$ & $\begin{array}{c}\text { Average } \\
0.97 \\
0.55 \\
0.91\end{array}$ & $\begin{array}{l}\text { Total } \\
1.4 \\
2.3 \\
3.0\end{array}$ & $\begin{array}{c}\text { Average } \\
84 \\
60\end{array}$ & $\begin{array}{c}\text { Average } \\
82 \\
58\end{array}$ \\
\hline P06-10 & 9.6 & 15.0 & $\begin{array}{c}\text { IRN2 } \\
\text { A } \\
\text { B }\end{array}$ & $\begin{array}{l}55.2 \\
82.5 \\
82.6\end{array}$ & $\begin{array}{l}0.99 \\
0.80 \\
0.81\end{array}$ & & $\begin{array}{l}59 \\
67\end{array}$ & \\
\hline P06-11 & 9.6 & 15.0 & $\begin{array}{c}\text { IRN2 } \\
\text { A } \\
\text { B }\end{array}$ & $\begin{array}{l}55.2 \\
82.5 \\
82.6\end{array}$ & $\begin{array}{l}0.99 \\
0.80 \\
0.81\end{array}$ & . & $\begin{array}{l}71 \\
74\end{array}$ & \\
\hline P06-12 & 9.6 & 14.9 & $\begin{array}{c}\text { IRN2 } \\
\text { A } \\
\text { B }\end{array}$ & $\begin{array}{l}55.2 \\
82.5 \\
82.6\end{array}$ & $\begin{array}{l}0.99 \\
0.81 \\
0.81\end{array}$ & & $\begin{array}{r}69 \\
73\end{array}$ & \\
\hline Internal Prob & Oss Results: & & & & & & & \\
\hline P06-10/12 & $\frac{\text { Average }}{9.6}$ & $\frac{\text { Average }}{14.9}$ & $\begin{array}{c}\text { IRN2 } \\
\text { A } \\
\text { B }\end{array}$ & $\begin{array}{c}\text { Average } \\
55.2 \\
82.5 \\
82.6\end{array}$ & $\begin{array}{c}\text { Average } \\
0.99 \\
0.81 \\
0.81\end{array}$ & $\begin{array}{c}\text { Total } \\
1.2 \\
1.4 \\
0.4\end{array}$ & $\begin{array}{c}\text { Average } \\
66 \\
71\end{array}$ & $\begin{array}{c}\text { Average } \\
65 \\
71\end{array}$ \\
\hline
\end{tabular}




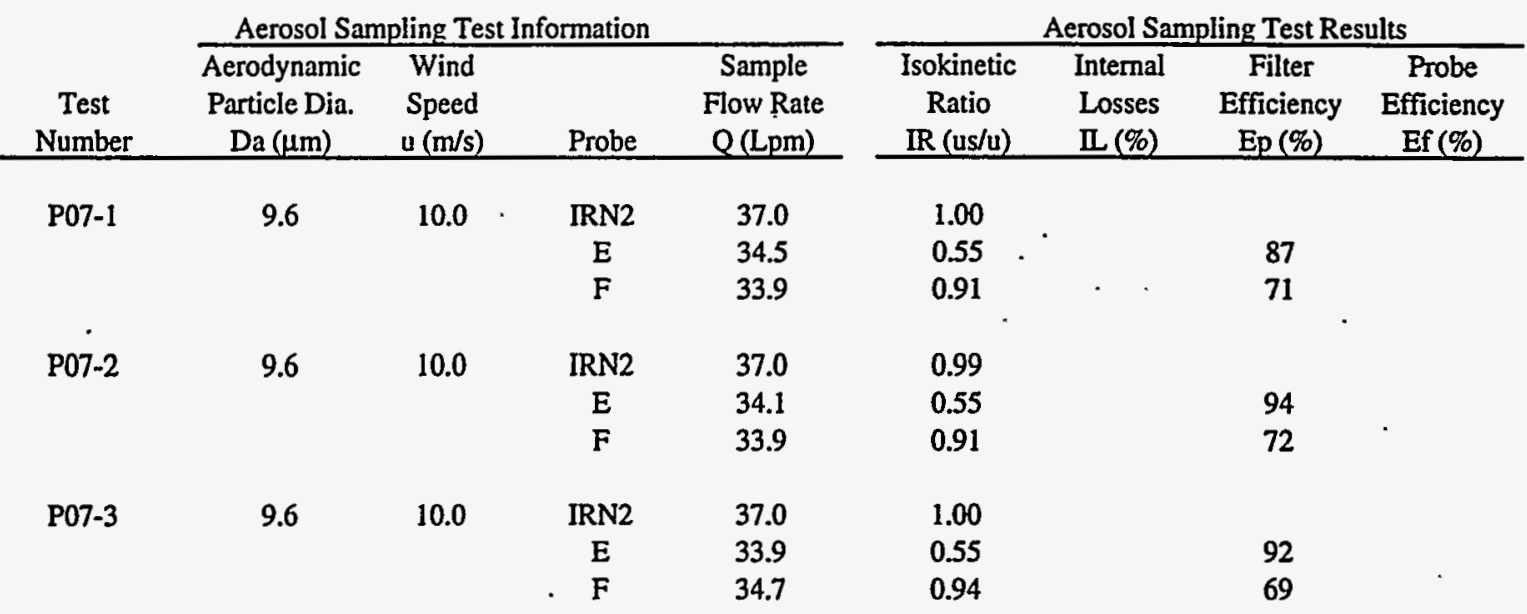

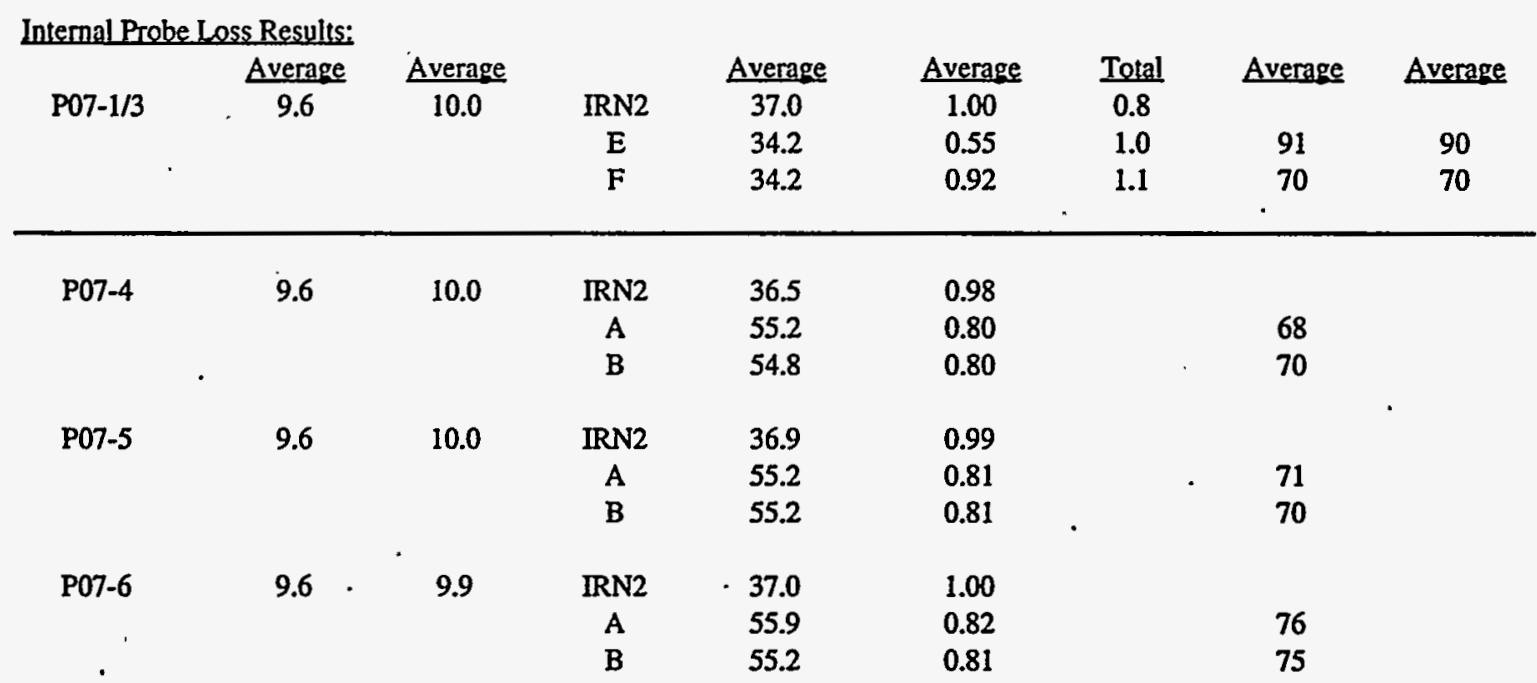

\begin{tabular}{|c|c|c|c|c|c|c|c|c|}
\hline \multicolumn{9}{|c|}{ Intemal Probe Loss Results: } \\
\hline \multirow{4}{*}{ P07-4/6 } & Average & Average & & Average & Average & Total & Average & Average \\
\hline & 9.6 & 10.0 & IRN2 & 36.8 & 0.99 & 0.6 & & \\
\hline & & & A & 55.4 & 0.81 & 0.8 & 72 & 71 \\
\hline & & & B & 55.1 & 0.81 & 1.5 & 72 & 71 \\
\hline
\end{tabular}




\begin{tabular}{|c|c|c|c|c|c|c|c|c|}
\hline & \multicolumn{4}{|c|}{ Aerosol Sampling Test Information } & \multicolumn{4}{|c|}{ Aerosol Sampling Test Results } \\
\hline $\begin{array}{c}\text { Test } \\
\text { Number }\end{array}$ & $\begin{array}{c}\text { Aerodynamic } \\
\text { Particle Dia. } \\
\text { Da }(\mu \mathrm{m})\end{array}$ & $\begin{array}{l}\text { Wind } \\
\text { Speed } \\
\mathrm{u}(\mathrm{m} / \mathrm{s})\end{array}$ & Probe & $\begin{array}{c}\text { Sample } \\
\text { Flow Rate } \\
\text { Q(Lpm) }\end{array}$ & $\begin{array}{c}\text { Isokinetic } \\
\text { Ratio } \\
\text { IR (us/u) }\end{array}$ & $\begin{array}{l}\text { Internal } \\
\text { Losses } \\
\text { IL (\%) } \\
\end{array}$ & $\begin{array}{c}\text { Filter } \\
\text { Efficiency } \\
\text { Ep }(\%)\end{array}$ & $\begin{array}{c}\text { Probe } \\
\text { Efficiency } \\
\text { Ef (\%) }\end{array}$ \\
\hline $\begin{array}{l}\text { P08-1 } \\
-\end{array}$ & 15.1 & 5.1 & $\begin{array}{c}\text { IRN2 } \\
\text { E } \\
\text { F }\end{array}$ & $\begin{array}{l}18.5 \\
17.5 \\
17.3\end{array}$ & $\begin{array}{l}0.98 \\
0.55 \\
0.92\end{array}$ & & $\begin{array}{l}59 \\
44\end{array}$ & \\
\hline P08-2 & 15.1 & 5.0 & $\begin{array}{c}\text { IRN2 } \\
\text { E } \\
\text { F }\end{array}$ & $\begin{array}{l}18.5 \\
17.5 \\
17.3\end{array}$ & $\begin{array}{l}0.99 \\
0.56 \\
0.93\end{array}$ & & $\begin{array}{l}59 \\
45\end{array}$ & \\
\hline P08-3 & 14.4 & 5.0 & $\begin{array}{c}\text { IRN2 } \\
\text { E } \\
\text { F }\end{array}$ & $\begin{array}{l}18.5 \\
17.5 \\
17.3\end{array}$ & $\begin{array}{l}0.99 \\
0.56 \\
0.93\end{array}$ & & $\begin{array}{l}57 \\
43\end{array}$ & - \\
\hline
\end{tabular}

Internal Probe Loss Results:

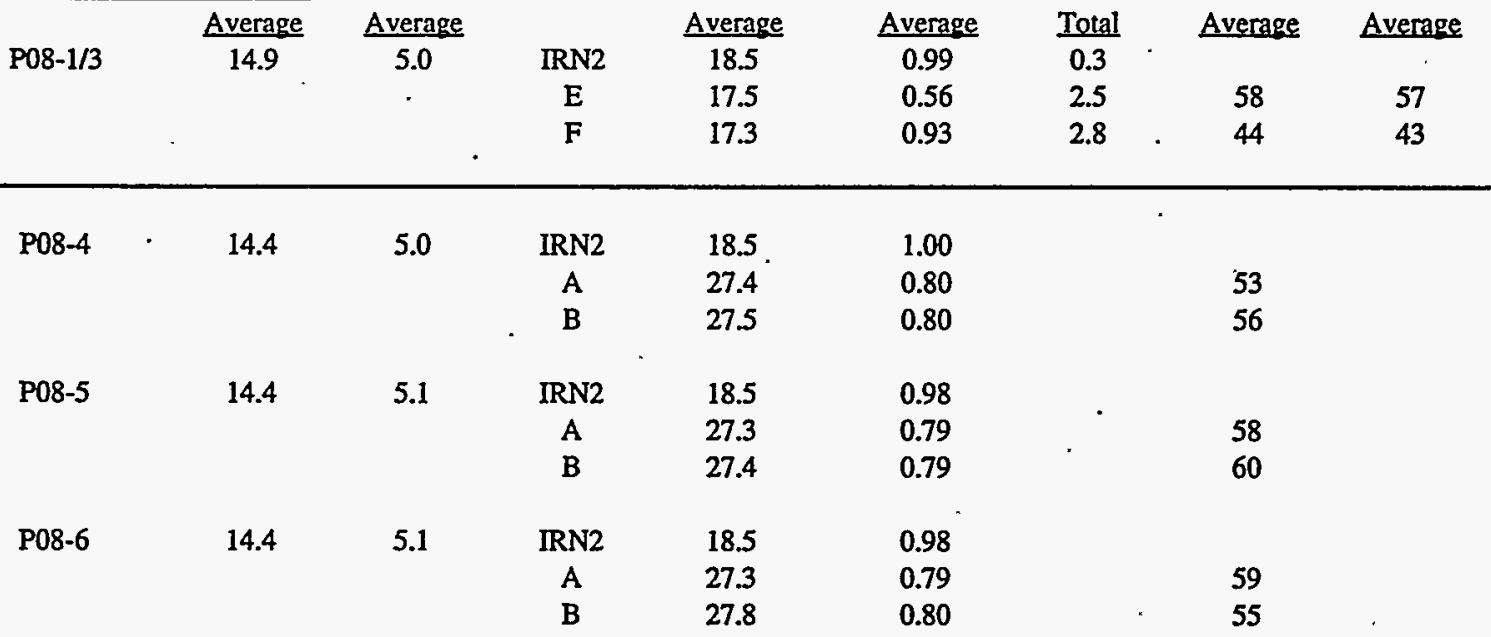

\begin{tabular}{|c|c|c|c|c|c|c|c|c|}
\hline & Average & Average & & Average & Average & Total & Average & Average \\
\hline \multirow[t]{3}{*}{ P08-4/6 } & 14.4 & 5.0 & IRN2 & 18.5 & 0.99 & 0.6 & & \\
\hline & & & $A$ & 27.3 & 0.79 & 2.1 & 57 & 55 \\
\hline & & & B & 27.6 & 0.80 & 3.8 & 57 & 55 \\
\hline
\end{tabular}




\begin{tabular}{|c|c|c|c|c|c|c|c|c|}
\hline \multirow[b]{2}{*}{$\begin{array}{c}\text { Test } \\
\text { Number }\end{array}$} & \multicolumn{3}{|c|}{ Aerosol Sampling Test Information } & & \multicolumn{4}{|c|}{ Aerosol Sampling Test Results } \\
\hline & $\begin{array}{c}\text { Aerodynamic } \\
\text { Particle Dia. } \\
\text { Da ( } \mu \mathrm{m})\end{array}$ & $\begin{array}{l}\text { Wind } \\
\text { Speed } \\
\mathrm{u}(\mathrm{m} / \mathrm{s})\end{array}$ & Probe & $\begin{array}{c}\text { Sample } \\
\text { Flow Rate } \\
\text { Q(Lpm) }\end{array}$ & $\begin{array}{c}\text { Isokinetic } \\
\text { Ratio } \\
\text { IR (us/u) }\end{array}$ & $\begin{array}{l}\text { Internal } \\
\text { Losses } \\
\text { IL (\%) } \\
\end{array}$ & $\begin{array}{c}\text { Filter } \\
\text { Efficiency } \\
\text { Ep (\%) }\end{array}$ & $\begin{array}{c}\text { Probe } \\
\text { Efficiency } \\
\text { Ef }(\%)\end{array}$ \\
\hline P08-7 & 14.4 & 15.0 & $\begin{array}{c}\text { IRN2 } \\
\text { E } \\
F\end{array}$ & $\begin{array}{l}55.2 \\
51.5 \\
51.4\end{array}$ & $\begin{array}{l}0.99 \\
0.55 \\
0.92\end{array}$ & & $\begin{array}{l}36 \\
30\end{array}$ & \\
\hline P08-8 & 14.4 & - 14.9 & $\begin{array}{l}\text { IRN2 } \\
\text { E } \\
\text { F }\end{array}$ & $\begin{array}{l}54.6 \\
51.5 \\
51.3\end{array}$ & $\begin{array}{l}0.98 \\
0.55 \\
0.92\end{array}$ & & $\begin{array}{l}35 \\
29\end{array}$ & \\
\hline P08-9 & 14.4 & 14.9 & $\begin{array}{c}\text { IRN2 } \\
\text { E } \\
\text { F }\end{array}$ & $\begin{array}{l}54.6 \\
51.5 \\
51.5\end{array}$ & $\begin{array}{l}0.99 \\
0.55 \\
0.93\end{array}$ & & $\begin{array}{l}35 \\
29\end{array}$ & \\
\hline
\end{tabular}

\begin{tabular}{|c|c|c|c|c|c|c|c|c|}
\hline \multicolumn{2}{|c|}{ InternaL Probe Loss Results: } & \multirow[b]{2}{*}{ Average } & & \multirow[b]{2}{*}{ Average } & \multirow[b]{2}{*}{ Average } & \multirow[b]{2}{*}{ Total } & \multirow[b]{2}{*}{ Average } & \multirow[b]{2}{*}{ Average } \\
\hline & Average & & & & & & & \\
\hline P06-7/9 & 14.4 & 14.9 & IRN2 & 54.8 & 0.99 & 2.7 & & \\
\hline & & & $\mathbf{E}$ & 51.5 & 0.55 & 9.1 & 35 & 32 \\
\hline & & & F & 51.4 & 0.92 & 10.5 & 30 & 27 \\
\hline P08-10 & 14.4 & 14.8 & IRN2 & 54.6 & 0.99 & & & \\
\hline & & & A & 82.4 & 0.81 & & 29 & \\
\hline & & & B & 82.6 & 0.81 & & 38 & \\
\hline P08-11 & 14.4 & 15.0 & IRN2 & 54.6 & 0.98 & & & \\
\hline & & & A & 82.4 & 0.80 & & 32 & $\cdot$ \\
\hline & & & B & 82.6 & 0.80 & & 39 & \\
\hline P08-12 & 14.4 & 15.0 & IRN2 & 54.6 & 0.98 & & & \\
\hline & & & A & 82.6 & 0.81 & & 33 & \\
\hline & & & B & 82.6 & 0.80 & & 40 & \\
\hline
\end{tabular}

\begin{tabular}{|c|c|c|c|c|c|c|c|c|}
\hline Intecoal Pro & $\begin{array}{l}\text { is Results } \\
\text { Average }\end{array}$ & Average & & Average & Average & Total & Average & Average \\
\hline \multirow{3}{*}{ P08-10/12 } & 14.4 & 14.9 & IRN2 & 54.6 & 0.98 & 2.8 & & \\
\hline & & & A & 82.5 & 0.81 & 4.1 & 31 & 30 \\
\hline & ; & . & B & 82.6 & 0.81 & 6.7 & 39 & 36 \\
\hline
\end{tabular}




\begin{tabular}{|c|c|c|c|c|c|c|c|c|}
\hline & Aerosol Sar & npling Tes & ormation & & & erosol Sa & ling Test Re & \\
\hline $\begin{array}{c}\text { Test } \\
\text { Number }\end{array}$ & $\begin{array}{c}\text { Aerodynamic } \\
\text { Particle Dia. } \\
\text { Da }(\mu \mathrm{m})\end{array}$ & $\begin{array}{c}\text { Wind } \\
\text { Speed } \\
u(\mathrm{~m} / \mathrm{s})\end{array}$ & Probe & $\begin{array}{c}\text { Sample } \\
\text { Flow Rate } \\
\mathrm{Q}(\mathrm{Lpm})\end{array}$ & $\begin{array}{c}\text { Isokinetic } \\
\text { Ratio } \\
\text { IR (us/u) }\end{array}$ & $\begin{array}{l}\text { Internal } \\
\text { Losses } \\
\text { IL (\%) }\end{array}$ & $\begin{array}{c}\text { Filter } \\
\text { Efficiency } \\
\text { Ep }(\%)\end{array}$ & $\begin{array}{c}\text { Probe } \\
\text { Efficiency } \\
\text { Ef }(\%)\end{array}$ \\
\hline P09-1 & 4.9 & 5.0 & IRN2 & 18.5 & 1.00 & & & \\
\hline & & & $E$ & 17.5 & 0.56 & & 200 & \\
\hline & & & $\mathrm{F}$ & 17.3 & 0.94 & & 84 & \\
\hline P09-2 & 4.9 & 5.0 & IRN2 & 18.5 & 0.99 & & & \\
\hline & & & E & 17.5 & 0.56 & & 93 & \\
\hline & & & $\mathrm{F}$ & 17.3 & 0.93 & & 83 & \\
\hline P09-3 & 4.9 & 5.0 & IRN2 & 18.5 & 0.99 & & & \\
\hline & & & $\mathbf{E}$ & 17.5 & 0.56 & & 100 & \\
\hline & & & F & 17.3 & 0.93 & & 88 & \\
\hline Internal Pro & Loss Results: & & & & & & & \\
\hline & Average & Average & & Average & Average & Total & Average & Average \\
\hline P09-1/3 & 4.9 & 5.0 & IRN2 & 18.5 & 0.99 & $\overline{0.0}$ & & \\
\hline & & & $\mathrm{E}$ & 17.5 & 0.56 & 0.1 & 131 & 131 \\
\hline & & & $\mathrm{F}$ & 17.3 & 0.93 & 0.2 & 85 & 85 \\
\hline P09-4 & 4.9 & 5.0 & IRN2 & 18.5 & 0.99 & & & \\
\hline & & & A & 27.3 & 0.80 & $\cdot$ & 92 & \\
\hline & & & B & 27.6 & 0.81 & & 82 & \\
\hline P09-5 & 4.9 & 5.0 & IRN2 & 18.5 & 1.00 & & & \\
\hline & & & A & 27.3 & 0.80 & & 95 & \\
\hline & & & B & 27.4 & 0.80 & & 65 & \\
\hline P09-6 & 4.9 & 5.0 & IRN2 & 18.5 & 1.00 & & & \\
\hline & & & A & 27.3 & 0.80 & & 93 & \\
\hline & & & B & 27.4 & 0.80 & & 86 & \\
\hline & $\cdot$ & & & & & & , & \\
\hline Intemal Pro & Loss Results: & & & & & & & \\
\hline & Average & Average & & Average & Average & Total & Average & Average \\
\hline P09-4/6 & 4.9 & 5.0 & IRN2 & 18.5 & 1.00 & 0.1 & & \\
\hline & & & A & 27.3 & 0.80 & 0.1 & 93 & 93 \\
\hline & & & B & 27.5 & 0.80 & 0.2 & 78 & 77 \\
\hline
\end{tabular}




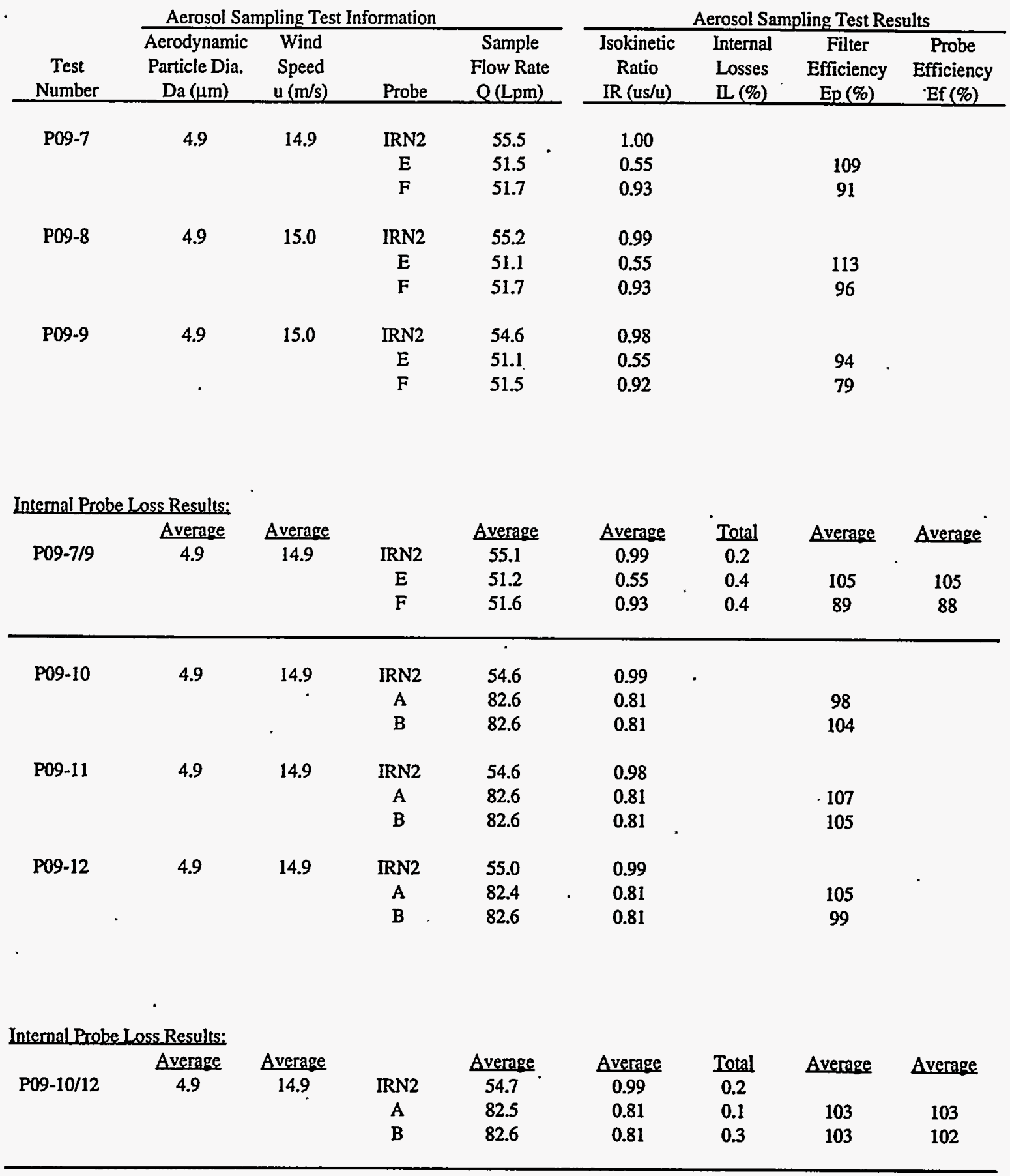




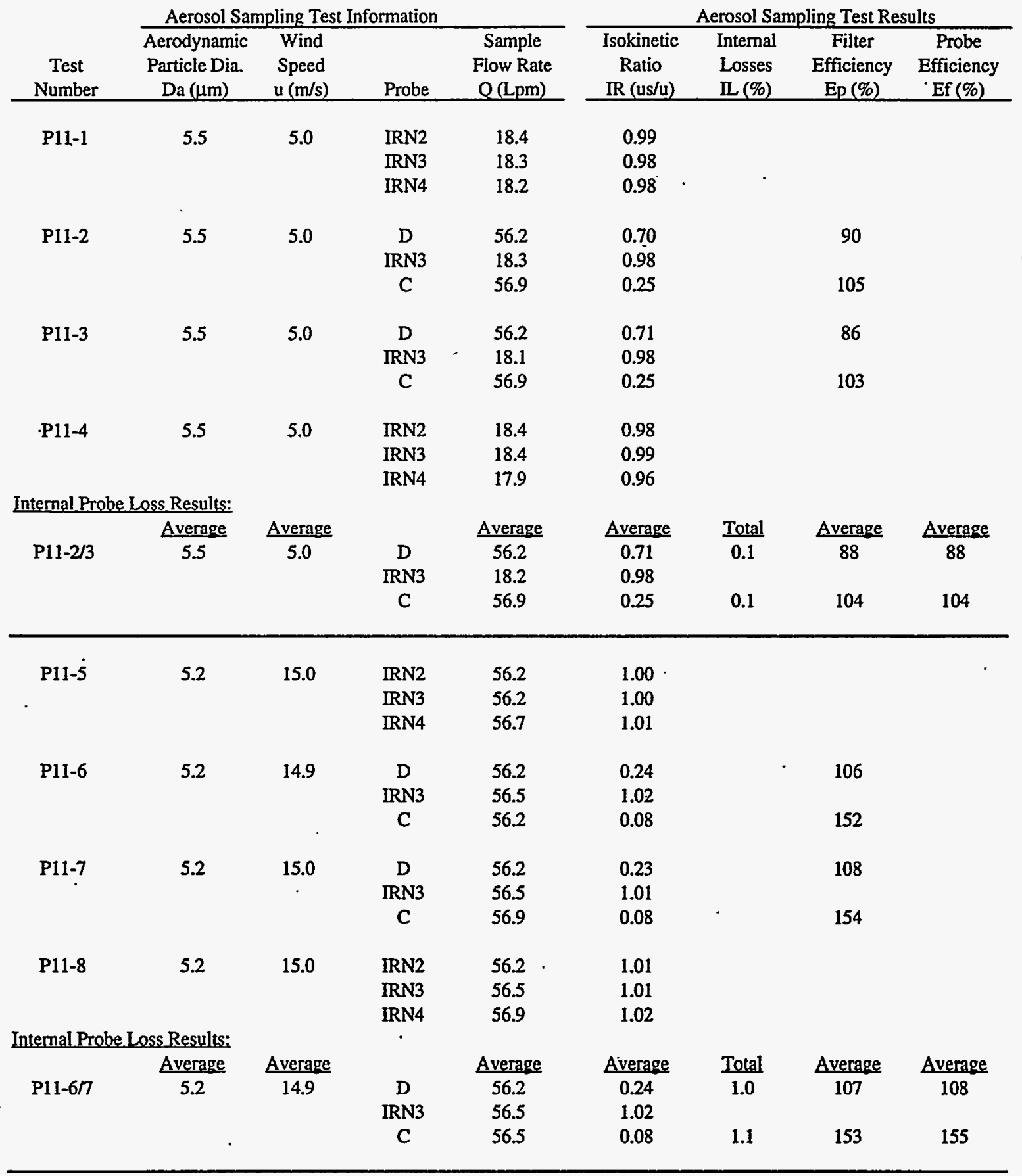




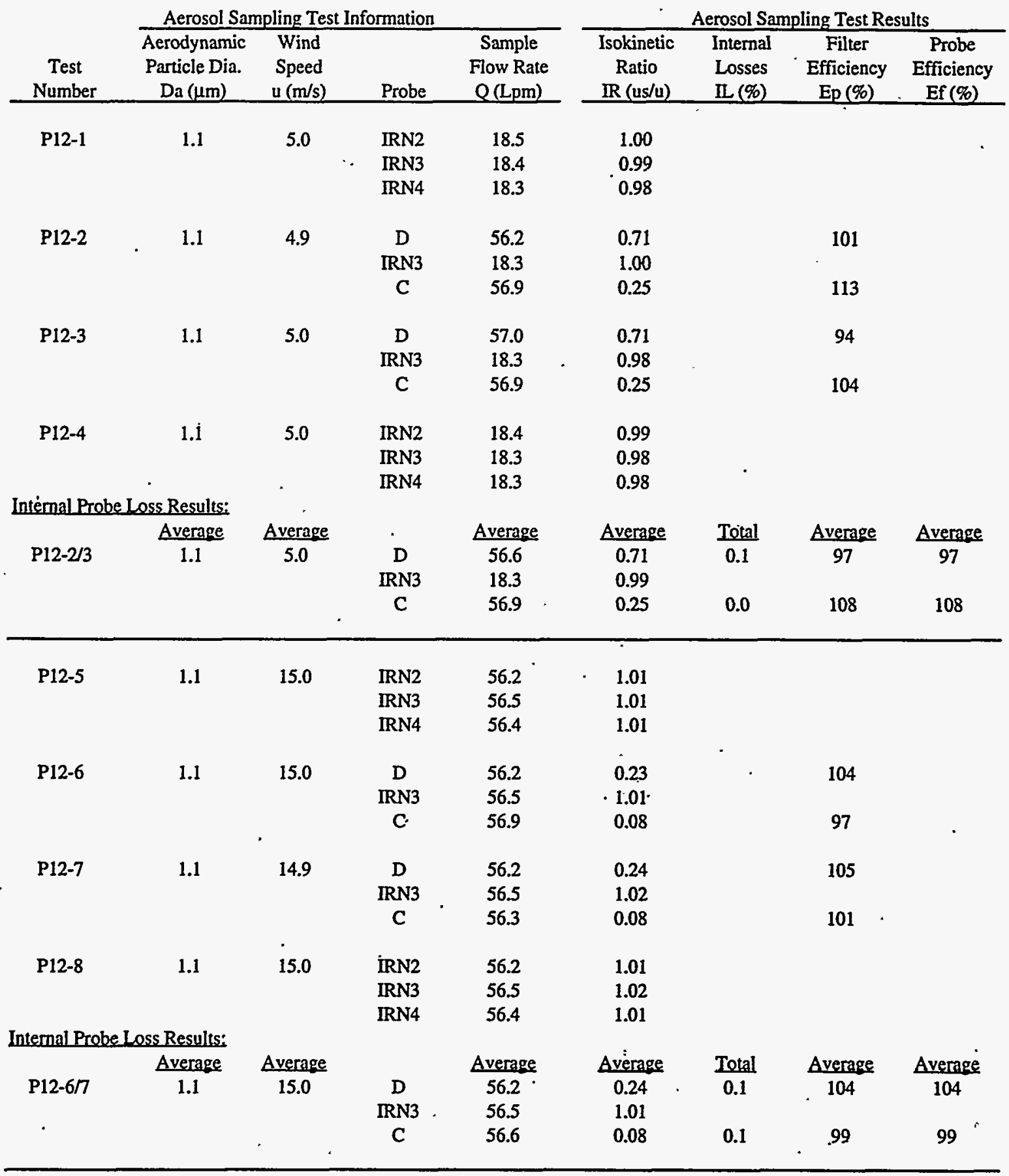




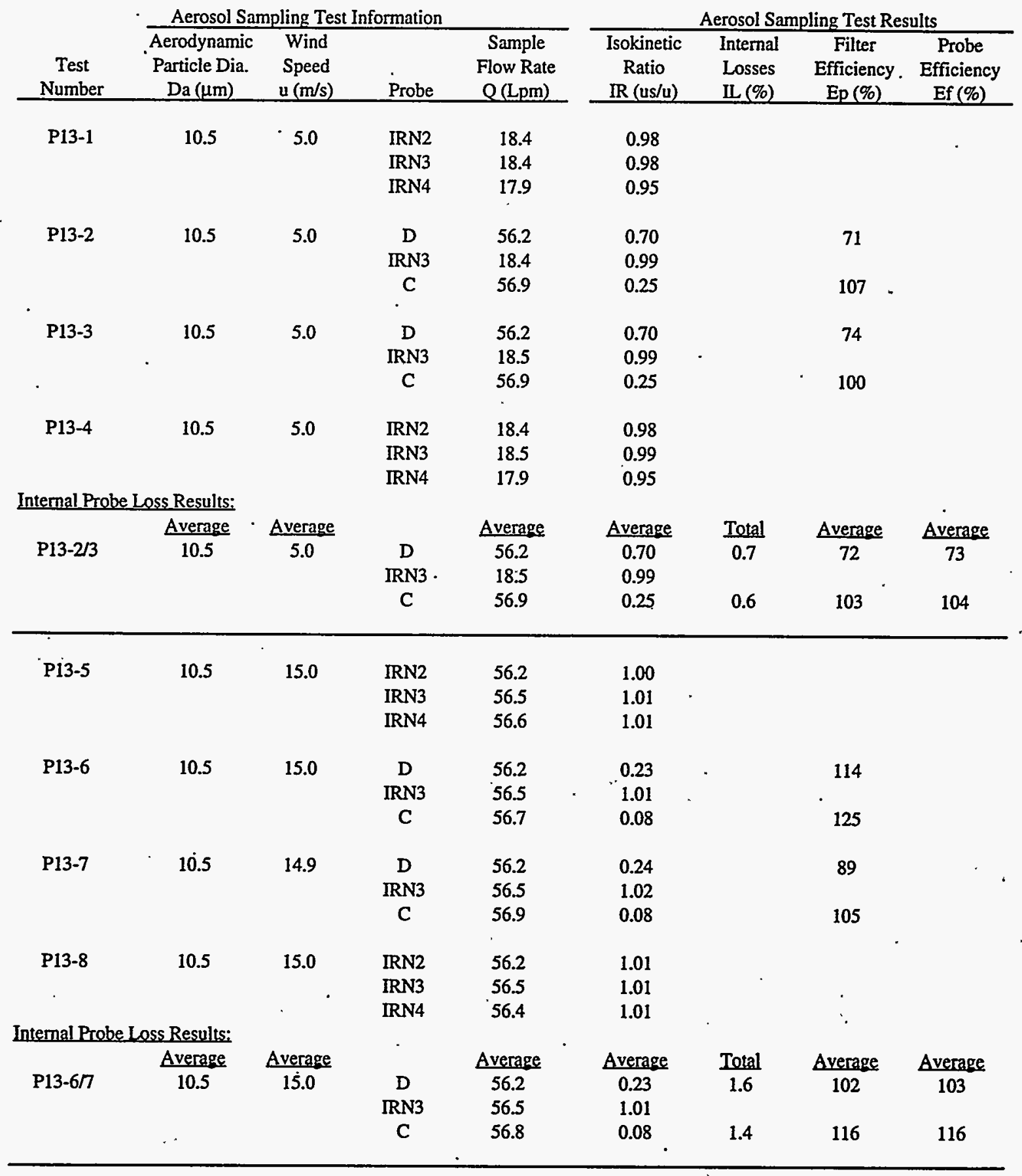




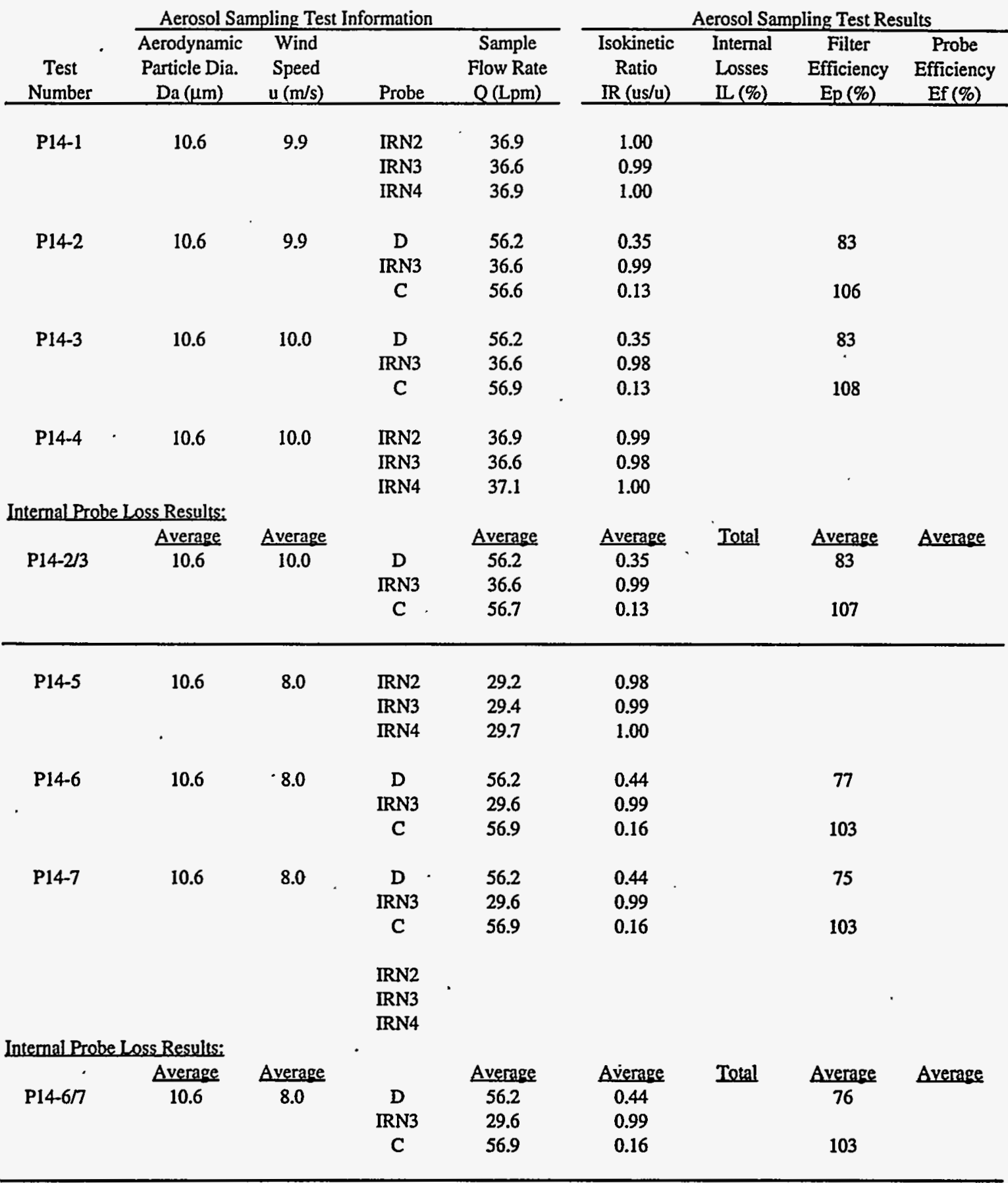

Used average of $\mathrm{P} 14-1,-4,-5: 100 \%$ (1/2 vs $2 / 3)$ and $103 \%$ (3/4 vs $2 / 3)$ for Ep calculations. 


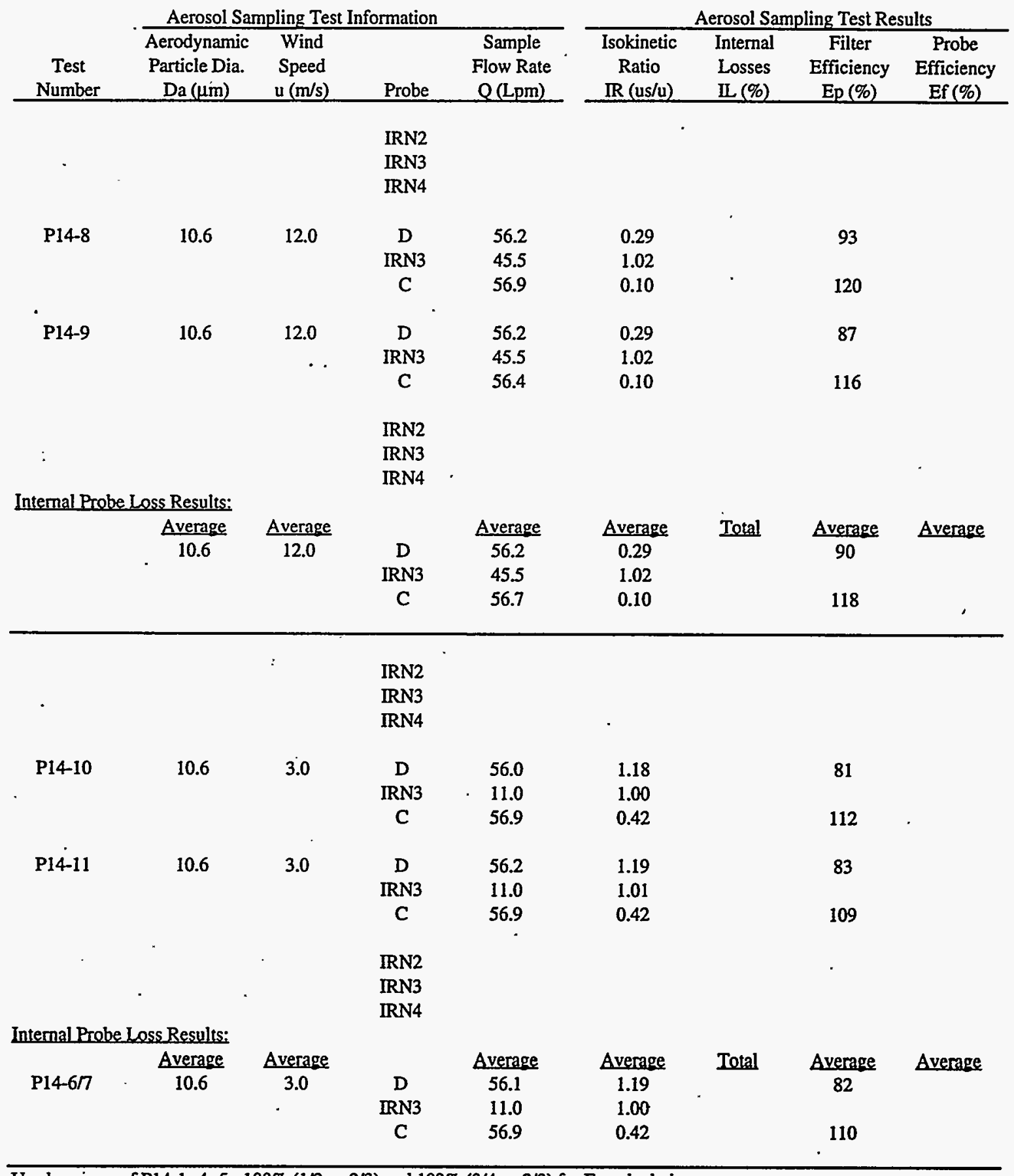

Used average of $P 14-1,-4,-5: 100 \%$ (1/2 vs $2 / 3)$ and $103 \%$ (3/4 vs $2 / 3)$ for Ep calculations. 


\begin{tabular}{|c|c|c|c|c|c|c|c|c|}
\hline \multirow[b]{2}{*}{$\begin{array}{c}\text { Test } \\
\text { Number } \\
\end{array}$} & \multicolumn{4}{|c|}{ Aerosol Sampling Test Information } & \multicolumn{4}{|c|}{ Aerosol Sampling Test Results } \\
\hline & $\begin{array}{c}\text { Aerodynamic } \\
\text { Particle Dia. } \\
\mathrm{Da}(\mu \mathrm{m})\end{array}$ & $\begin{array}{c}\text { Wind } \\
\text { Speed } \\
\mathrm{u}(\mathrm{m} / \mathrm{s})\end{array}$ & Probe & $\begin{array}{c}\text { Sample } \\
\text { Flow Rate } \\
\mathrm{Q}(\mathrm{Lpm}) \\
\end{array}$ & $\begin{array}{c}\text { Isokinetic } \\
\text { Ratio } \\
\text { IR (US/u) } \\
\end{array}$ & $\begin{array}{l}\text { Internal } \\
\text { Losses } \\
\text { IL (\%) } \\
\end{array}$ & $\begin{array}{c}\text { Filter } \\
\text { Efficiency } \\
\text { Ep (\%) }\end{array}$ & $\begin{array}{c}\text { Probe } \\
\text { Efficiency } \\
\text { Ef (\%) }\end{array}$ \\
\hline P15-1 & 15.9 & 5.0 & $\begin{array}{l}\text { IRN2 } \\
\text { IRN3 } \\
\text { IRN4 }\end{array}$ & $\begin{array}{l}18.4 \\
18.3 \\
18.3\end{array}$ & $\begin{array}{l}0.99 \\
0.98 \\
0.98\end{array}$ & & & \\
\hline P15-2 & 15.9 & 5.0 & $\begin{array}{c}\text { D } \\
\text { IRN3 } \\
\text { C }\end{array}$ & $\begin{array}{l}56.2 \\
18.3 \\
56.8\end{array}$ & $\begin{array}{l}0.70 \\
0.98 \\
0.25\end{array}$ & & $\begin{array}{l}51 \\
72\end{array}$ & \\
\hline P15-3 & 15.9 & 5.0 & $\begin{array}{c}\text { D } \\
\text { IRN3 } \\
\text { C }\end{array}$ & $\begin{array}{l}56.2 \\
18.1 \\
56.9\end{array}$ & $\begin{array}{l}0.70 \\
0.97 \\
0.25\end{array}$ & & $\begin{array}{l}49 \\
76\end{array}$ & \\
\hline P15-4 & 15.9 & 5.0 & $\begin{array}{l}\text { IRN2 } \\
\text { IRN3 } \\
\text { IRN4 }\end{array}$ & $\begin{array}{l}18.4 \\
18.3 \\
17.9\end{array}$ & $\begin{array}{l}0.99 \\
0.98 \\
0.96\end{array}$ & & & \\
\hline $\begin{array}{c}\text { Internal Pro } \\
\text { P15-2/3 }\end{array}$ & $\frac{\text { oss Results: }}{\frac{\text { Average }}{15.9}}$ & $\begin{array}{c}\text { Average } \\
5.0\end{array}$ & $\begin{array}{c}\text { D } \\
\text { IRN3 } \\
\text { C }\end{array}$ & $\begin{array}{c}\text { Average } \\
56.2 \\
18.2 \\
56.9\end{array}$ & $\begin{array}{c}\text { Average } \\
0.70 \\
0.98 \\
0.25\end{array}$ & $\begin{array}{c}\frac{\text { Total }}{3.7} \\
3.4\end{array}$ & $\begin{array}{c}\frac{\text { Average }}{50} \\
74\end{array}$ & $\begin{array}{c}\text { Average } \\
52 \\
76\end{array}$ \\
\hline P15-5 & 15.9 & 15.0 & $\begin{array}{l}\text { IRN2 } \\
\text { IRN3 } \\
\text { IRN4 }\end{array}$ & $\begin{array}{l}56.2 \\
56.5 \\
56.9\end{array}$ & $\begin{array}{l}1.01 \\
1.01 \\
1.02\end{array}$ & & & \\
\hline P15-6 & 15.9 & 15.0 & $\begin{array}{c}\text { D } \\
\text { IRN3 } \\
\text { C }\end{array}$ & $\begin{array}{l}56.2 \\
56.7 \\
56.9\end{array}$ & $\begin{array}{l}0.23 \\
1.02 \\
0.08\end{array}$ & . & $\begin{array}{r}86 \\
141\end{array}$ & \\
\hline P15-7 & 15.9 & 15.0 & $\begin{array}{c}\text { D } \\
\text { IRN3 } \\
\text { C }\end{array}$ & $\begin{array}{l}56.2 \\
56.7 \\
56.9\end{array}$ & $\begin{array}{l}0.23 \\
1.02 \\
0.08\end{array}$ & & $\begin{array}{l}90 \\
140\end{array}$ & \\
\hline P15-8 & 15.9 & 15.0 & $\begin{array}{l}\text { IRN2 } \\
\text { IRN3 } \\
\text { IRN4 }\end{array}$ & $\begin{array}{l}56.1 \\
56.5 \\
56.9\end{array}$ & $\begin{array}{l}1.01 \\
1.01 \\
1.02\end{array}$ & & & \\
\hline InternaL Prob & Oss Results: & & & & & & & \\
\hline $\mathrm{P} 15-6 / 7$ & $\frac{\text { Average }}{15.9}$ & $\frac{\text { Average }}{15.0}$ & $\begin{array}{c}\text { D } \\
\text { IRN3 } \\
\text { C }\end{array}$ & $\begin{array}{c}\text { Average } \\
56.2 \\
56.7 \\
56.9\end{array}$ & $\begin{array}{c}\text { Average } \\
0.23 \\
1.02 \\
0.08\end{array}$ & $\frac{\text { Total }}{15.5}$ & $\frac{\text { Average }}{88}$ & $\frac{\text { Average }}{103}$ \\
\hline
\end{tabular}




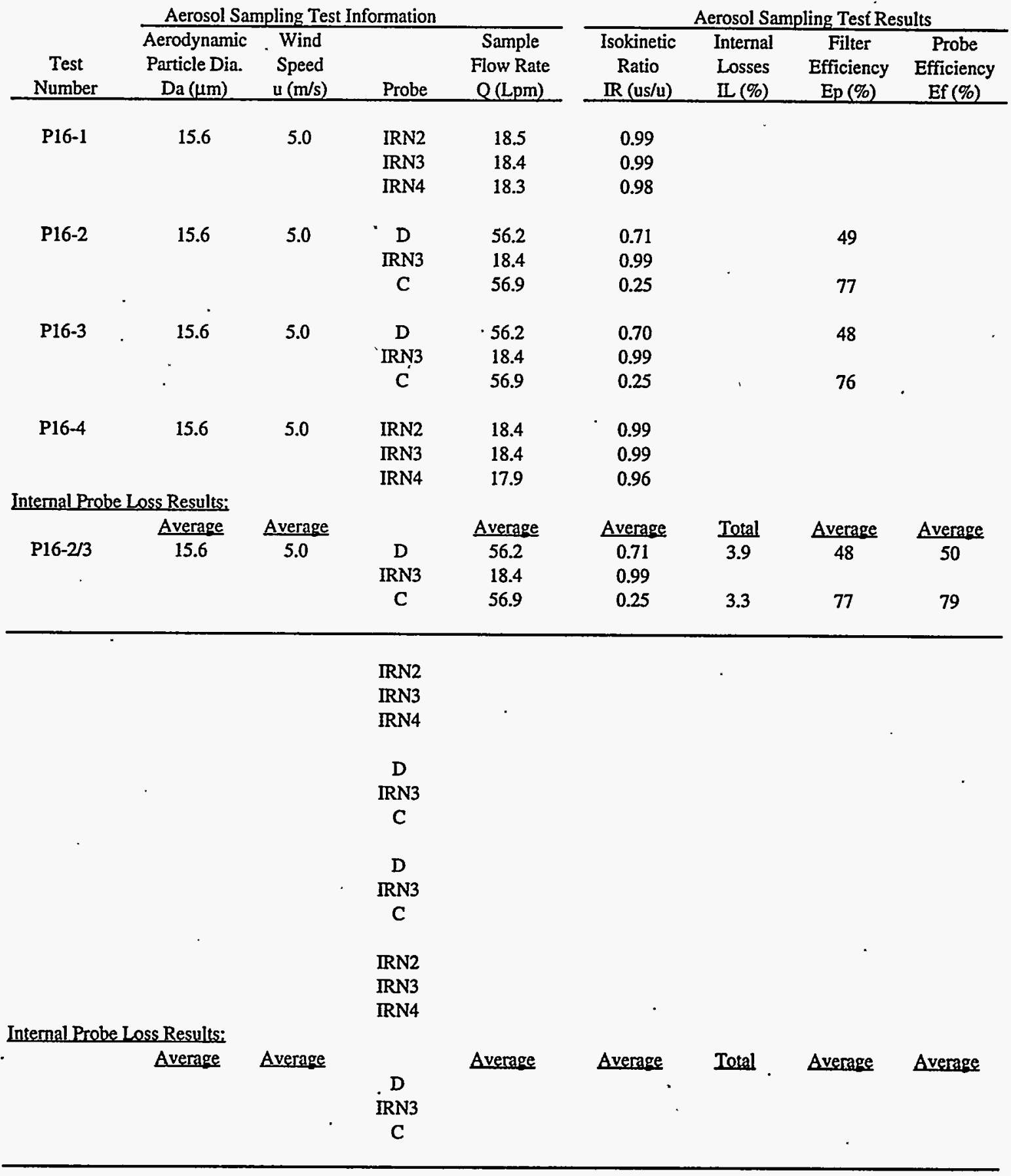




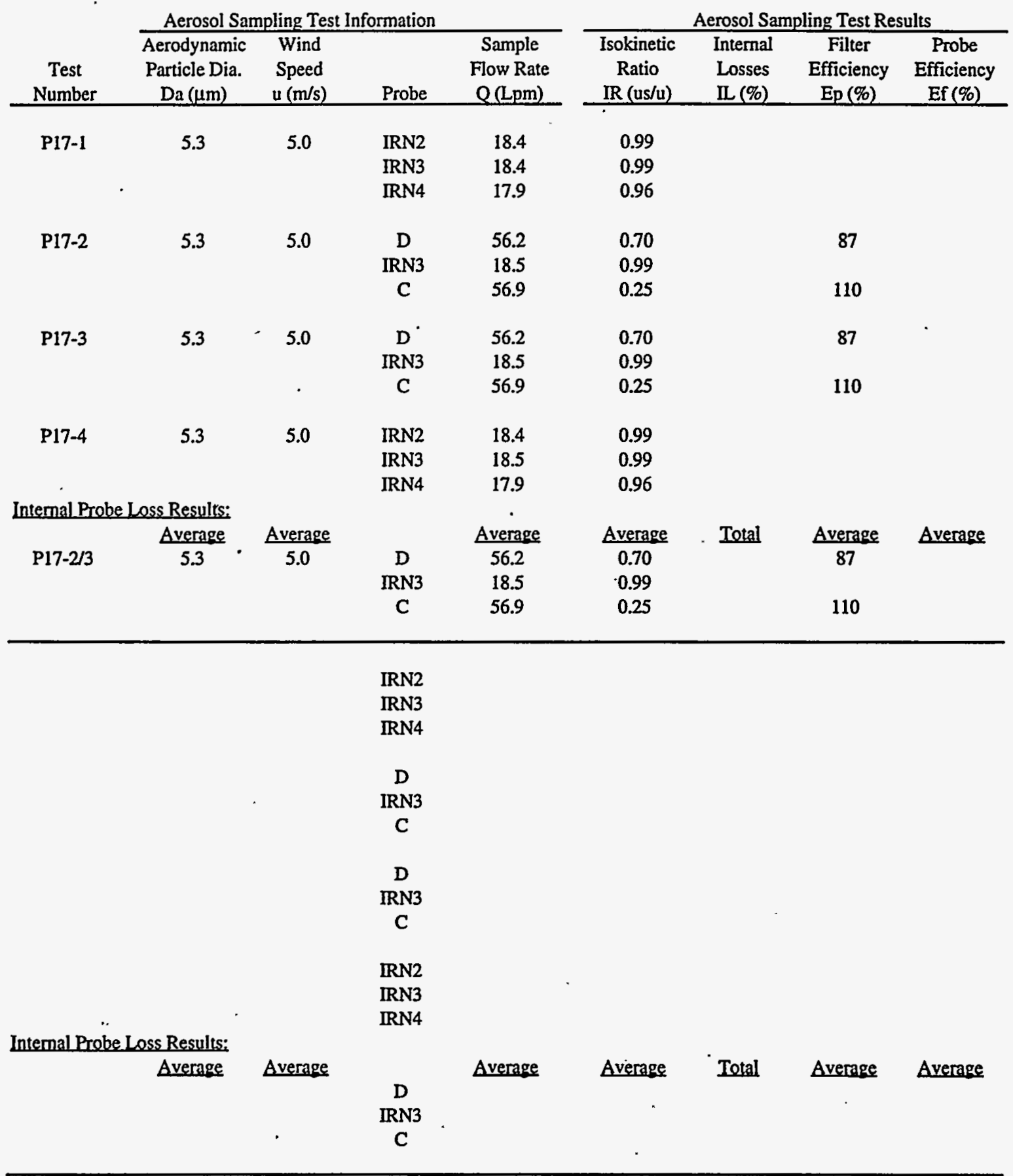




\begin{tabular}{|c|c|c|c|c|c|c|c|c|}
\hline & Aerosol Sar & npling Test & ormation & & & erosol Sar & ling Test Res & \\
\hline $\begin{array}{c}\text { Test } \\
\text { Number }\end{array}$ & $\begin{array}{c}\text { Aerodynamic } \\
\text { Particle Dia. } \\
\mathrm{Da}(\mu \mathrm{m})\end{array}$ & $\begin{array}{c}\text { Wind } \\
\text { Speed } \\
\mathrm{u}(\mathrm{m} / \mathrm{s})\end{array}$ & Probe & $\begin{array}{c}\text { Sample } \\
\text { Flow Rate } \\
\text { Q(Lpm) }\end{array}$ & $\begin{array}{c}\text { Isokinetic } \\
\text { Ratio } \\
\text { IR (us/u) } \\
\end{array}$ & $\begin{array}{l}\text { Internal } \\
\text { Losses } \\
\text { IL }(\%) \\
\end{array}$ & $\begin{array}{c}\text { Filter } \\
\text { Efficiency } \\
\text { Ep }(\%)\end{array}$ & $\begin{array}{l}\text { Probe } \\
\text { Efficiency } \\
\text { Ef }(\%)\end{array}$ \\
\hline P18-1 & 10.2 & 5.0 & IRN2 & 18.7 & 1.01 & & & \\
\hline & & & IRN3 & 18.5 & 1.00 & & & \\
\hline & & & IRN4 & 18.3 & 0.99 & & & \\
\hline P18-2 & 10.2 & 5.0 & B & 27.5 & 0.79 & & 82 & \\
\hline & & & IRN3 & 18.6 & 0.99 & & & \\
\hline & & & A & 27.8 & 0.80 & & 86 & \\
\hline P18-3 & 10.2 & 5.0 & B & $27: 6$ & 0.80 & & 75 & \\
\hline & & & IRN3 & 18.6 & 0.99 & & & \\
\hline & & & A & 27.9 & 0.81 & & 92 & \\
\hline P18-6 & 10.2 & 5.0 & IRN2 & 18.6 & 1.00 & & & \\
\hline & & & IRN3 & 18.6 & 1.00 & & & \\
\hline & & & IRN4 & 18.3 & 0.98 & & & \\
\hline Internal Prol & Oss Results: & & & & & & & \\
\hline & Average & Average & & Average & Average & Total & Average & Average \\
\hline & 10.2 & 5.0 & B & 27.5 & 0.80 & & 79 & \\
\hline & & & IRN3 & 18.6 & 0.99 & & & \\
\hline & & & A & 27.8 & 0.81 & & 89 & \\
\hline P18-1 & 10.2 & 5.0 & IRN2 & 18.7 & 1.01 & & & . \\
\hline & & & IRN3 & 18.5 & 1.00 & & & \\
\hline & & & IRN4 & 18.3 & 0.99 & & & \\
\hline P18-4 & 10.2 & 5.0 & F & 17.2 & 0.92 & & 74 & \\
\hline & & & IRN3 & 18.6 & 0.99 . & & & \\
\hline & & & E & 17.1 & 0.55 & & 98 & \\
\hline P18-5 & 10.2 & 5.0 & $\mathrm{~F}$ & 17.2 & 0.92 & & 73 & \\
\hline & & & IRN3 & 18.6 & 0.99 & & & \\
\hline & & & $\mathrm{E}$ & .17 .2 & 0.55 & & 98 & \\
\hline P18-6 & 10.2 & 5.0 & IRN2 & 18.6 & 1.00 & & & \\
\hline & & & IRN3 & 18.6 & 1.00 & & & \\
\hline & & & IRN4 & 18.3 & 0.98 & & & \\
\hline Internal Prot & oss Results: & & & & & & & \\
\hline & Average & Average & & Average & Average & Total & Average & Average \\
\hline & 10.2 & 5.0 & $\mathbf{F}$ & 17.2 & 0.92 & & 74 & \\
\hline & & & IRN3 & 18.6 & 0.99 & & & \\
\hline & & & E & 17.1 & 0.55 & & 98 & \\
\hline
\end{tabular}




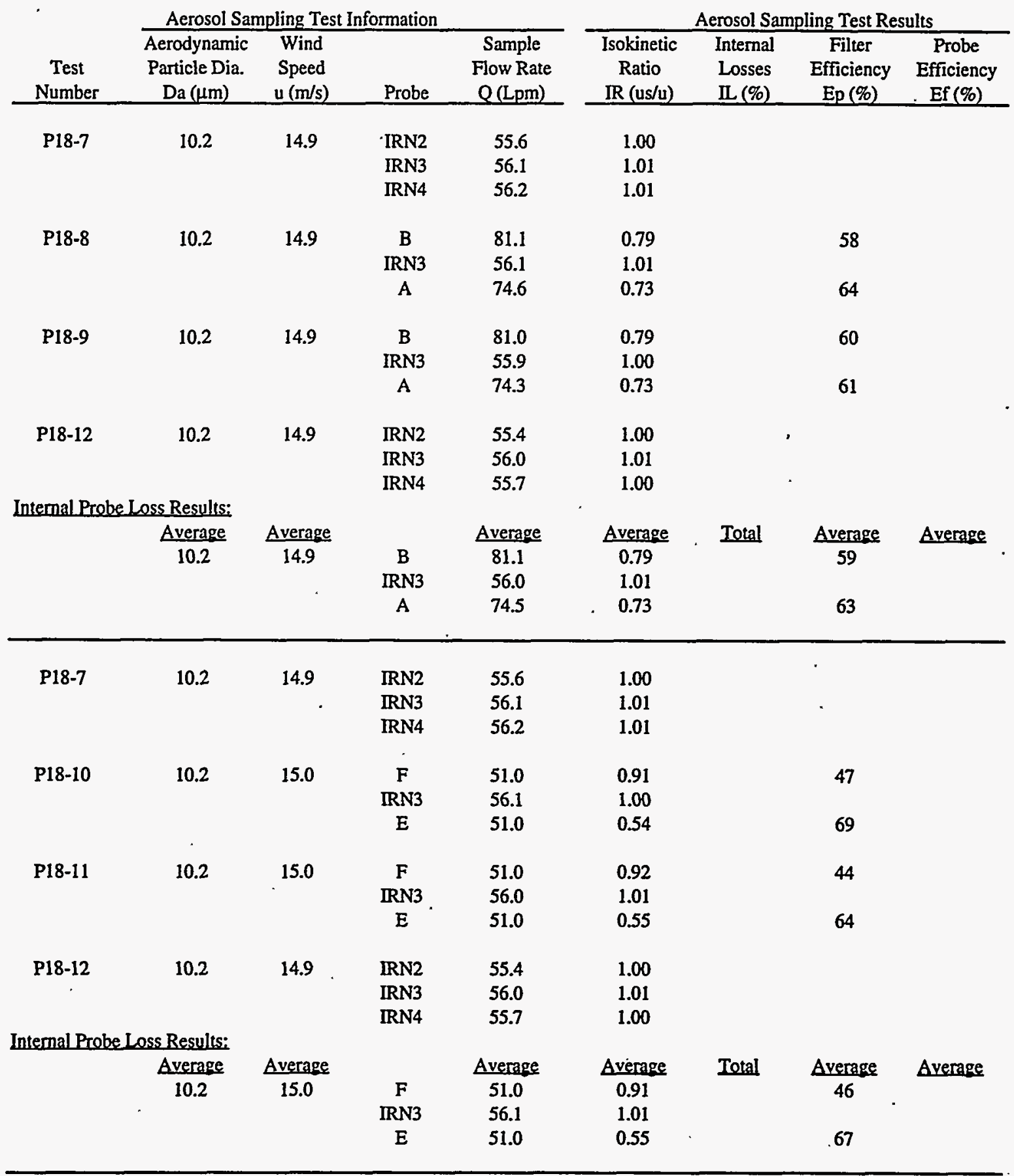




\begin{tabular}{|c|c|c|c|c|c|c|c|c|}
\hline & Aerosol Sar & npling Test & ormation & & & erosol Sa & ling Test Re & \\
\hline $\begin{array}{c}\text { Test } \\
\text { Number }\end{array}$ & $\begin{array}{c}\text { Aerodynamic } \\
\text { Particle Dia. } \\
\text { Da }(\mu \mathrm{m})\end{array}$ & $\begin{array}{c}\text { Wind } \\
\text { Speed } \\
u(\mathrm{~m} / \mathrm{s})\end{array}$ & Probe & $\begin{array}{c}\text { Sample } \\
\text { Flow Rate } \\
\text { Q(Lpm) }\end{array}$ & $\begin{array}{c}\text { Isokinetic } \\
\text { Ratio } \\
\text { IR (us/u) }\end{array}$ & $\begin{array}{l}\text { Internal } \\
\text { Losses } \\
\text { IL (\%) } \\
\end{array}$ & $\begin{array}{c}\text { Filter } \\
\text { Efficiency } \\
\text { Ep (\%) }\end{array}$ & $\begin{array}{c}\text { Probe } \\
\text { Efficiency } \\
\text { Ef }(\%)\end{array}$ \\
\hline P19-1 & 15.7 & 5.0 & IRN2 & 18.7 & 1.01 & & & \\
\hline & & & IRN3 & 18.5 & 1.00 & & & \\
\hline & & & IRN4 & 18.7 & 1.01 & & & \\
\hline P19-2 & 15.7 & 5.0 & B & 27.4 & 0.80 & & 60 & \\
\hline & & & IRN3 & 18.5 & 0.99 & & & \\
\hline & & & A & 27.7 & 0.81 & & 67 & \\
\hline P19-3 & 15.7 & 5.0 & B & 27.4 & 0.80 & & 60 & \\
\hline & & & IRN3 & 18.5 & 1.00 & & $\cdot$ & \\
\hline & & & A & $27: 9$ & 0.82 & & 72 & \\
\hline P19-6 & 15.5 & 5.0 & IRN2 & 18.7 & 1.01 & & & \\
\hline & & & IRN3 & 18.4 & 0.99 & . & & \\
\hline & & & IRN4 & 18.3 & 0.99 & & & \\
\hline Internal Prol & oss Results: & & & & & & & \\
\hline & Average & Average & & Average & Average & Total & Average & Average \\
\hline P19-2/3 & 15.7 & 5.0 & B & 27.4 & 0.80 & 3.8 . & 60 & 63 \\
\hline & & & IRN3 & 18.5 & 1.00 & & & \\
\hline & & & A & 27.8 & 0.81 & 2.5 & 70 & 71 \\
\hline P19-1 & 15.7 & 5.0 & IRN2 & 18.7 & 1.01 & & & . \\
\hline & & & IRN3 & 18.5 & 1.00 & & & \\
\hline & & & IRN4 & 18.7 & 1.01 & & & \\
\hline P19-4 & 15.5 & 5.0 & F & 17.5 & 0.93 & & 49 & \\
\hline & & & IRN3 & .18 .5 & 0.99 & & & \\
\hline & & & $\mathbf{E}$ & 17.1 & 0.54 & & 59 & \\
\hline P19-5 & 15.5 & 5.0 & F & 17.5 & 0.94 & & 49 & \\
\hline & & & IRN3 & 18.4 & 0.99 & & & \\
\hline & & & $\mathrm{E}$ & 17.1 & 0.55 & & 58 & \\
\hline P19-6 & 15.5 & 5.0 & IRN2 & 18.7 & 1.01 & & & \\
\hline & & & IRN3 & 18.4 & 0.99 & & & \\
\hline & & & IRN4 & 18.3 & 0.99 & & & \\
\hline Internal Prob & Qss Results: & & . & & & & & \\
\hline & Average & Average & & Average & Average & Total & Average. & Average \\
\hline P19-4/5 & 15.5 & 5.0 & F & 17.5 & 0.94 & 4.0 & 49 & 51 \\
\hline & & & IRN3 & 18.5 & 0.99 & & & \\
\hline & & & $E$ & 17.1 & 0.54 & 5.1 & 58 & 61 \\
\hline
\end{tabular}




\begin{tabular}{|c|c|c|c|c|c|c|c|c|}
\hline \multirow[b]{2}{*}{$\begin{array}{c}\text { Test } \\
\text { Number }\end{array}$} & \multicolumn{3}{|c|}{ Aerosol Sampling Test Information } & & \multicolumn{4}{|c|}{ Aerosol Sampling Test Results } \\
\hline & $\begin{array}{l}\text { Aerodynamic } \\
\text { Particle Dia. } \\
\mathrm{Da}(\mu \mathrm{m})\end{array}$ & $\begin{array}{l}\text { Wind } \\
\text { Speed } \\
\mathrm{u}(\mathrm{m} / \mathrm{s})\end{array}$ & Probe & $\begin{array}{c}\text { Sample } \\
\text { Flow Rate } \\
\text { Q(Lpm) }\end{array}$ & $\begin{array}{c}\text { Isokinetic } \\
\text { Ratio } \\
\text { IR (us/u) } \\
\end{array}$ & $\begin{array}{l}\text { Internal } \\
\text { Losses } \\
\text { IL (\%) }\end{array}$ & $\begin{array}{c}\text { Filter } \\
\text { Efficiency } \\
\text { Ep (\%) }\end{array}$ & $\begin{array}{c}\text { Probe } \\
\text { Efficiency } \\
\text { Ef (\%) }\end{array}$ \\
\hline P20-1 & 5.3 & 5.0 & $\begin{array}{l}\text { IRN2 } \\
\text { IRN3 } \\
\text { IRN4 }\end{array}$ & $\begin{array}{l}18.7 \\
18.6 \\
18.7\end{array}$ & $\begin{array}{l}1.00 \\
1.00 \\
1.00\end{array}$ & & & \\
\hline P20-2 & 5.3 & 5.0 & $\begin{array}{c}\text { B } \\
\text { IRN3 } \\
\text { A }\end{array}$ & $\begin{array}{l}27.7 \\
18.6 \\
27.8\end{array}$ & $\begin{array}{l}0.80 \\
0.99 \\
0.81\end{array}$ & - & $\begin{array}{l}106 \\
112\end{array}$ & \\
\hline P20-3 & 5.3 & 5.0 & $\begin{array}{c}\text { B } \\
\text { IRN3 } \\
\text { A }\end{array}$ & $\begin{array}{l}27.4 \\
18.7 \\
27.9\end{array}$ & $\begin{array}{l}0.80 \\
1.00 \\
0.81\end{array}$ & & $\begin{array}{l}101 \\
108\end{array}$ & \\
\hline P20-6 & 5.3 & 5.0 & $\begin{array}{l}\text { IRN2 } \\
\text { IRN3 } \\
\text { IRN4 }\end{array}$ & $\begin{array}{l}18.7 \\
18.6 \\
18.3\end{array}$ & $\begin{array}{l}1.00 \\
0.99 \\
0.97\end{array}$ & & & \\
\hline Internal PTo & $\frac{\text { oss Results: }}{\frac{\text { Average }}{5.3}}$ & $\frac{\text { Average }}{5.0}$ & $\begin{array}{c}\text { B } \\
\text { IRN3 }\end{array}$ & $\begin{array}{c}\text { Average } \\
27.5 \\
18.7 \\
27.9\end{array}$ & $\begin{array}{c}\text { Average } \\
0.80 \\
1.00 \\
0.81\end{array}$ & Total & $\begin{array}{c}\frac{\text { Average }}{104} \\
110\end{array}$ & Average \\
\hline P20-1 & 5.3 & 5.0 & $\begin{array}{l}\text { IRN2 } \\
\text { IRN3 } \\
\text { IRN4 }\end{array}$ & $\begin{array}{l}18.7 \\
18.6 \\
18.7\end{array}$ & $\begin{array}{l}1.00 \\
1.00 \\
1.00\end{array}$ & & & \\
\hline P20-4 & 5.3 & 5.1 & $\begin{array}{c}\text { F } \\
\text { IRN3 } \\
\text { E }\end{array}$ & $\begin{array}{l}17.8 \\
18.4 \\
17.6\end{array}$ & $\begin{array}{r}0.95 \\
\cdot 0.98 \\
0.56\end{array}$ & & $\begin{array}{l}95 \\
111\end{array}$ & \\
\hline P20-5 & 5.3 & 5.0 & $\begin{array}{c}F \\
\text { IRN3 } \\
\text { E }\end{array}$ & $\begin{array}{l}17.5 \\
18.6 \\
17.2\end{array}$ & $\begin{array}{l}0.93 \\
0.99 \\
0.55\end{array}$ & & $\begin{array}{l}92 \\
112\end{array}$ & \\
\hline P20-6 & $\begin{array}{c}5.3 \\
.\end{array}$ & 5.0 & $\begin{array}{l}\text { IRN2 } \\
\text { IRN3 } \\
\text { IRN4 }\end{array}$ & $\begin{array}{l}18.7 \\
18.6 \\
18.3\end{array}$ & $\begin{array}{l}1.00 \\
0.99 \\
0.97\end{array}$ & & & \\
\hline InternaL Pro & $\begin{array}{c}\text { Oss Results: } \\
\frac{\text { Average }}{5.3}\end{array}$ & $\frac{\text { Average }}{5.0}$ & $\begin{array}{c}\text { F } \\
\text { IRN3 } \\
\text { E }\end{array}$ & $\begin{array}{c}\text { Average } \\
17.7 \\
18.5 \\
17.4\end{array}$ & $\begin{array}{c}\text { Average } \\
0.94 \\
0.99 \\
0.55\end{array}$ & Tetal & $\begin{array}{c}\text { Average } \\
94 \\
112\end{array}$ & Average \\
\hline
\end{tabular}

Note: There was a flow problem during 1 st $5 \%$ of $\mathrm{P} 20-4$ ( $<\sim 5$ to $10 \%$ impact on result); efficiencies may be 5 to $10 \%$ too high. 


\begin{tabular}{|c|c|c|c|c|c|c|c|c|}
\hline & Aerosol Sa & mpling Test & rmation & & & erosol Sa & ling Test Re & \\
\hline $\begin{array}{c}\text { Test } \\
\text { Number }\end{array}$ & $\begin{array}{c}\text { Aerodynamic } \\
\text { Particle Dia. } \\
\mathrm{Da}(\mu \mathrm{m})\end{array}$ & $\begin{array}{c}\text { Wind } \\
\text { Speed } \\
u(\mathrm{~m} / \mathrm{s}) \\
\end{array}$ & Probe & $\begin{array}{c}\text { Sample } \\
\text { Flow Rate } \\
\mathrm{Q}(\mathrm{Lpm})\end{array}$ & $\begin{array}{c}\text { Isokinetic } \\
\text { Ratio } \\
\text { IR (us/u) }\end{array}$ & $\begin{array}{l}\text { Internal } \\
\text { Losses } \\
\mathrm{IL}(\%) \\
\end{array}$ & $\begin{array}{c}\text { Filter } \\
\text { Efficiency } \\
\text { Ep }(\%) \\
\end{array}$ & $\begin{array}{c}\text { Probe } \\
\text { Efficiency } \\
\text { Ef (\%) } \\
\end{array}$ \\
\hline P20-7 & 5.3 & 15.0 & IRN2 & 55.8 & 1.00 & & & \\
\hline & - & & IRN3 & 56.0 & 1.00 & & & \\
\hline & & & IRN4 & 55.8 & 1.00 & & & \\
\hline P20-8 & 5.3 & 14.9 & B & 81.0 & 0.79 & & 97 & \\
\hline & & & IRN3 & 55.9 & 1.00 & & & \\
\hline & & & $\cdot \mathrm{A}$ & 74.5 & 0.73 & & 105 & \\
\hline P20-9 & 5.3 & 14.9 & B & 80.1 & 0.78 & & 105 & \\
\hline & & & IRN3 & 55.8 & 1.00 & & & \\
\hline & & & A & 74.3 & 0.73 & & 104 & \\
\hline P20-12 & 5.3 & 15.0 & IRN2 & 55.8 & 1.00 & & . & \\
\hline & & & IRN3 & 56.1 & 1.01 & & & \\
\hline & & & IRN4 & 55.7 & 1.00 & & & \\
\hline Internal Prol & Loss Results: & & & & & & & \\
\hline & Average & Average & & Average & Average & Total & Average & Average \\
\hline & 5.3 & 14.9 & B & 80.5 & 0.79 & & 100 & \\
\hline • & & & IRN3 & 55.8 & 1.00 & & & \\
\hline & & & A & 74.4 & 0.73 & & 105 & \\
\hline P20-7 & 5.3 & 15.0 & IRN2 & 55.8 & 1.00 & & & \\
\hline & & & IRN3 & 56.0 & 1.00 & & & \\
\hline & & & IRN4 & 55.8 & 1.00 & & & · \\
\hline P20-10 & 5.3 & 15.0 & F & 51.0 & 0.91 & & 91 & \\
\hline & & & IRN3 & 56.1 & 1.00 & & & \\
\hline & . & - & E & 51.0 & 0.54 & & 122 & \\
\hline P20-11 & 5.3 & 15.0 & $\mathrm{~F}$ & 51.1 & 0.91 & & 99 & \\
\hline & & & IRN3 & 55.8 & 1.00 & & & \\
\hline & . & & E & 51.0 & 0.54 & & 112 & \\
\hline P20-12 & 5.3 & 15.0 & IRN2 & 55.8 & 1.00 & & & \\
\hline & & & IRN3 & 56.1 & 1.01 & & & \\
\hline & & & IRN4 & 55.7 & 1.00 & & & \\
\hline Internal Prot & OSs Results: & & & & & & & \\
\hline & Average & Average & & Average & Average & Total & Average & Average \\
\hline & 5.3 & 15.0 & $\mathrm{~F}$ & 51.1 & 0.91 & & 94 & \\
\hline & & & IRN3 & 56.0 & 1.00 & & & \\
\hline & & & $\mathbf{E}$ & 51.0 & 0.54 & & 118 & \\
\hline
\end{tabular}




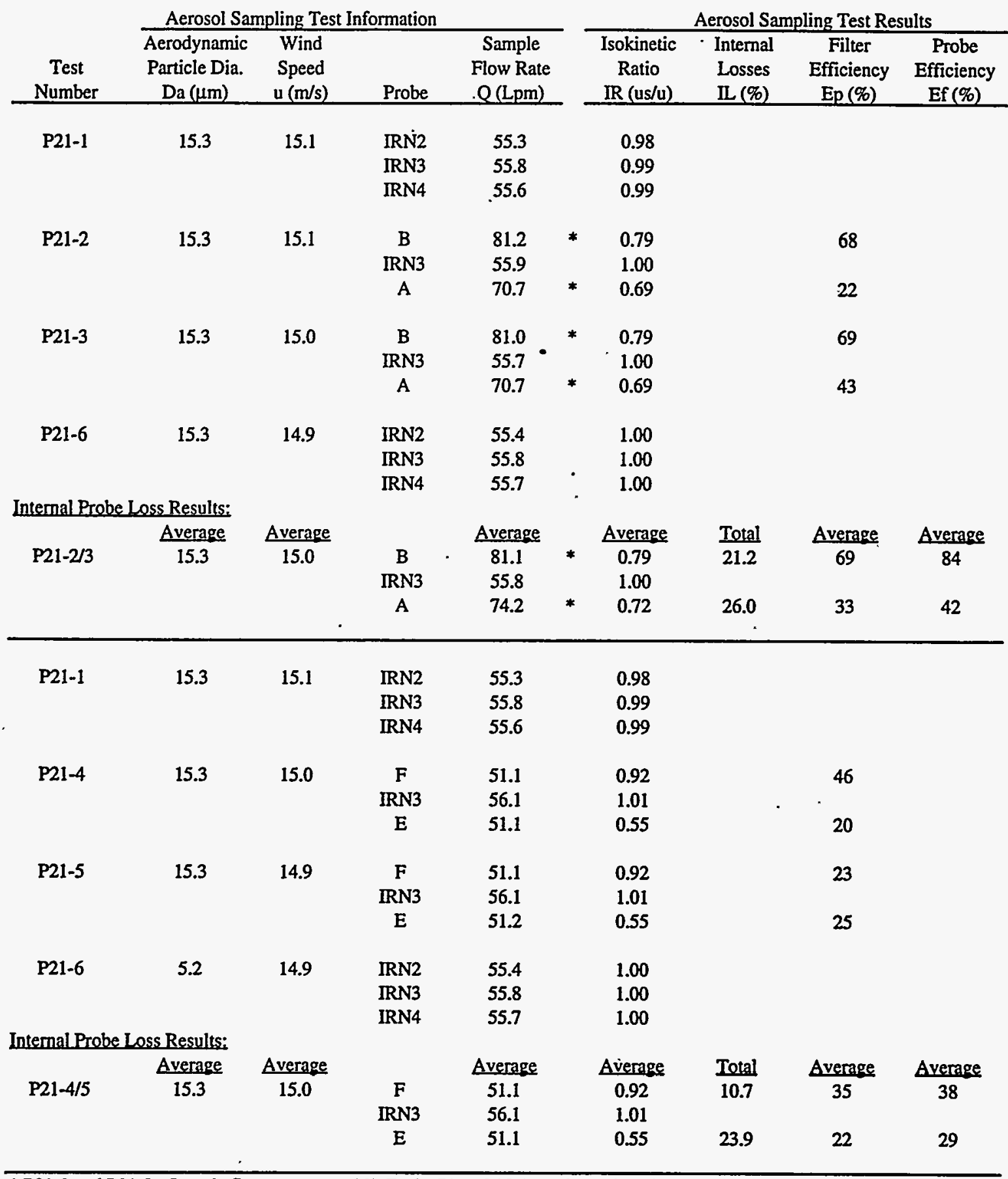

* P21-2 and P21-3: Sample flow rates were 2\% (Probe B) and 15\% (Probe A) less than target flow rates. 


\begin{tabular}{|c|c|c|c|c|c|c|c|c|}
\hline & Aerosol Sar & npling Test & ormation & & & erosol $\mathrm{Sa}$ & ling Test $R e$ & \\
\hline $\begin{array}{c}\text { Test } \\
\text { Number }\end{array}$ & $\begin{array}{c}\text { Aerodynamic } \\
\text { Particle Dia. } \\
\mathrm{Da}(\mu \mathrm{m})\end{array}$ & $\begin{array}{l}\text { Wind } \\
\text { Speed } \\
\mathrm{u}(\mathrm{m} / \mathrm{s})\end{array}$ & Probe & $\begin{array}{c}\text { Sample } \\
\text { Flow Rate } \\
\text { Q(Lpm) }\end{array}$ & $\begin{array}{c}\text { Isokinetic } \\
\text { Ratio } \\
\text { IR (us/u) } \\
\end{array}$ & $\begin{array}{l}\text { Internal } \\
\text { Losses } \\
\text { IL }(\%) \\
\end{array}$ & $\begin{array}{c}\text { Filter } \\
\text { Efficiency } \\
\text { Ep (\%) }\end{array}$ & $\begin{array}{c}\text { Probe } \\
\text { Efficiency } \\
\text { Ef }(\%)\end{array}$ \\
\hline P22-1 & 10.3 & 2.9 & IRN2 & 11.5 & 1.07 & & & \\
\hline & & & IRN3 & 11.1 & 1.03 & & . & . \\
\hline & & & IRN4 & 11.3 & 1.05 & & & \\
\hline P22-2 & 10.3 & 3.0 & D & 14.1 & 0.29 & & 95 & \\
\hline & & & IRN3 & 11.1 & 0.98 & & & \\
\hline & & & $\mathrm{C}$ & 37.8 & 0.27 & & 114 & \\
\hline P22-3 & 10.3 & 3.0 & D & 14.1 & 0.29 & & 85 & \\
\hline & & & IRN3 & 11.1 & 1.00 & & & \\
\hline & & & C & 37.8 & 0.28 & & 113 & \\
\hline P22-4 & 10.3 & 3.0 & IRN2 & 11.5 & 1.03 & & & . \\
\hline & & & IRN3 & 11.1 & 0.99 & & & \\
\hline & & & IRN4" & 11.6 & 1.03 & & & \\
\hline Internal Pro & Loss Results: & & & & & & & \\
\hline & Average & Average & & Average & Average & Total & Average & Average \\
\hline & 10.3 & 3.0 & D & 14.1 & 0.29 & & .90 & \\
\hline & & & IRN3 & 11.1 & 0.99 & & & \\
\hline & & & C & 37.8 & 0.28 & & 113 & . \\
\hline P22-5 & 10.3 & 5.0 & IRN2 & 18.6 & 1.00 & & & \\
\hline & & & IRN3 & 18.8 & 1.01 & & & \\
\hline & & & IRN4 & 18.7 & 1.01 & & & \\
\hline P22-6 & 10.3 & 5.0 & D & 23.6 & 0.30 & & 96 & \\
\hline & & & IRN3 & 18.8 & 1.01 & & & \\
\hline & & & C & 63.1 & 0.28 & & 84 & \\
\hline P22-7 & 10.3 & 5.0 & D & 23.6 & 0.30 & & 94 & \\
\hline & & & IRN3 & 18.8 & 1.01 & & & \\
\hline . & & & C & 63.1 & 0.28 & & 86 & \\
\hline P22-8 & 10.3 & 5.0 & IRN2 & 18.6 & 1.00 & & & \\
\hline & & & IRN3 & 18.8 & 1.01 & & & \\
\hline & & & IRN4 & 18.7 & 1.01 & & & \\
\hline Intemal Pro & Loss Results: & & & & & & & \\
\hline & Average & & & Average & Average & Total & Average & Average \\
\hline & 10.3 & 5.0 & D & 23.6 & 0.30 & & 95 & . \\
\hline & & & IRN3 & 18.8 & 1.01 & & & \\
\hline . & & & C & 63.1 & 0.28 & & 85 & \\
\hline
\end{tabular}

Note: Variable target flow rates for $\mathrm{C}$ and $\mathrm{D}$ (only $3 \& 5 \mathrm{~m} / \mathrm{s}$ for $\mathrm{C}$ ). 


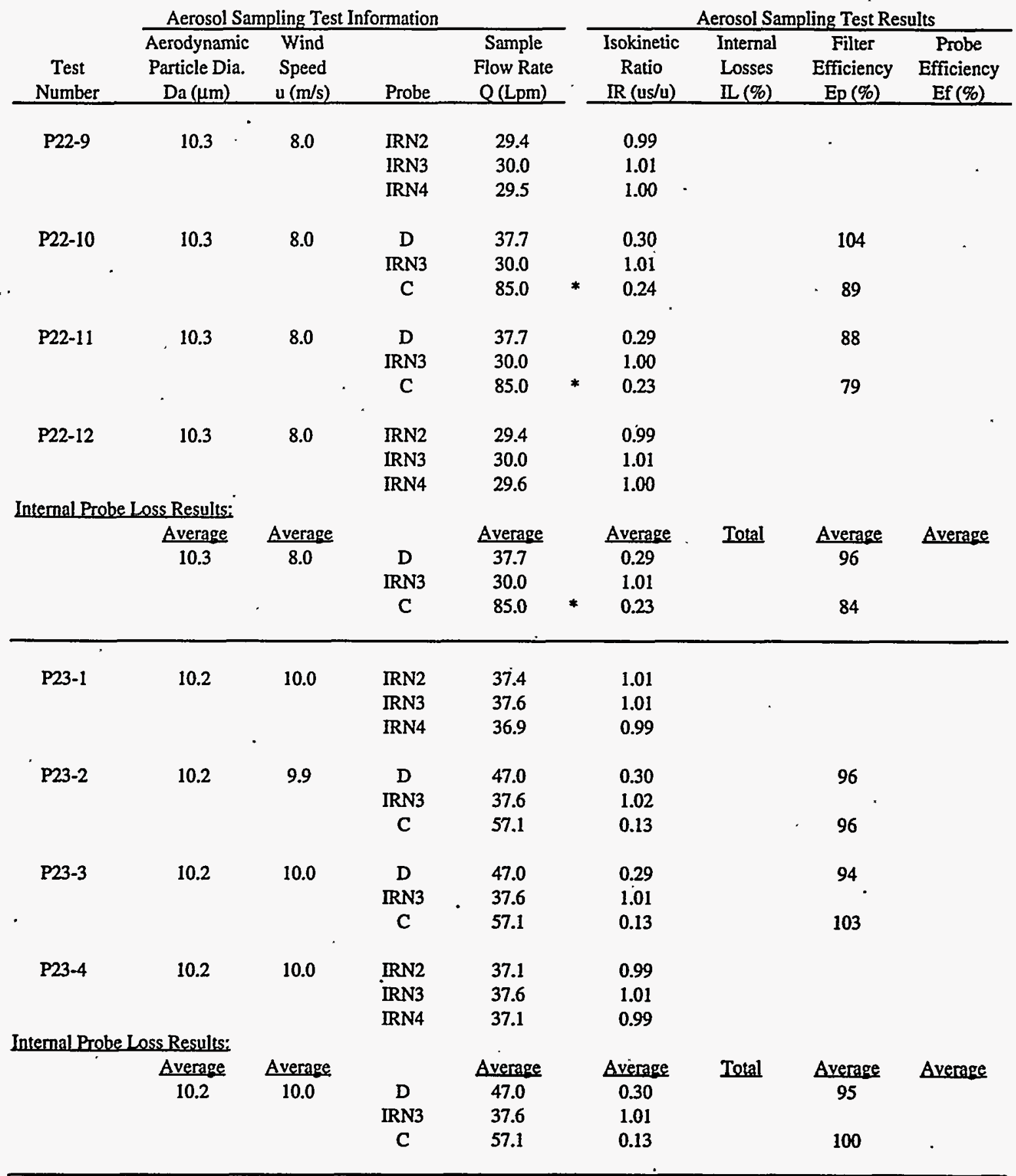

* Note: Variable target flow rates for C and D (only $3 \& 5 \mathrm{~m} / \mathrm{s}$ for C). Probe C actual flow was estimated for the $8 \mathrm{~m} / \mathrm{s}$ case. 


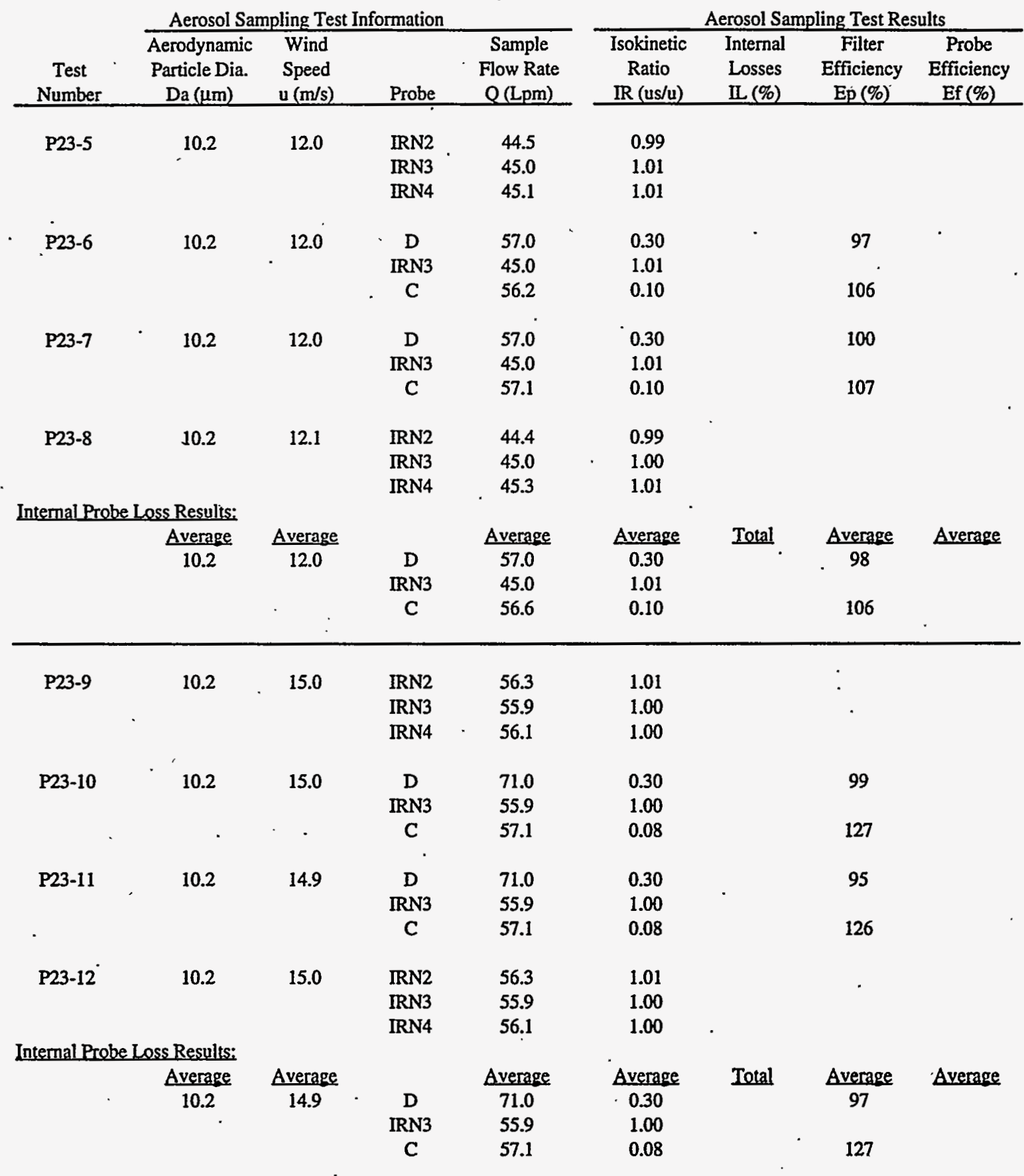

Note: Variable target flow rates for $C$ and $D$ (only $3 \& 5 \mathrm{~m} / \mathrm{s}$ for $C$ ). 
Splitter Test Worksheet

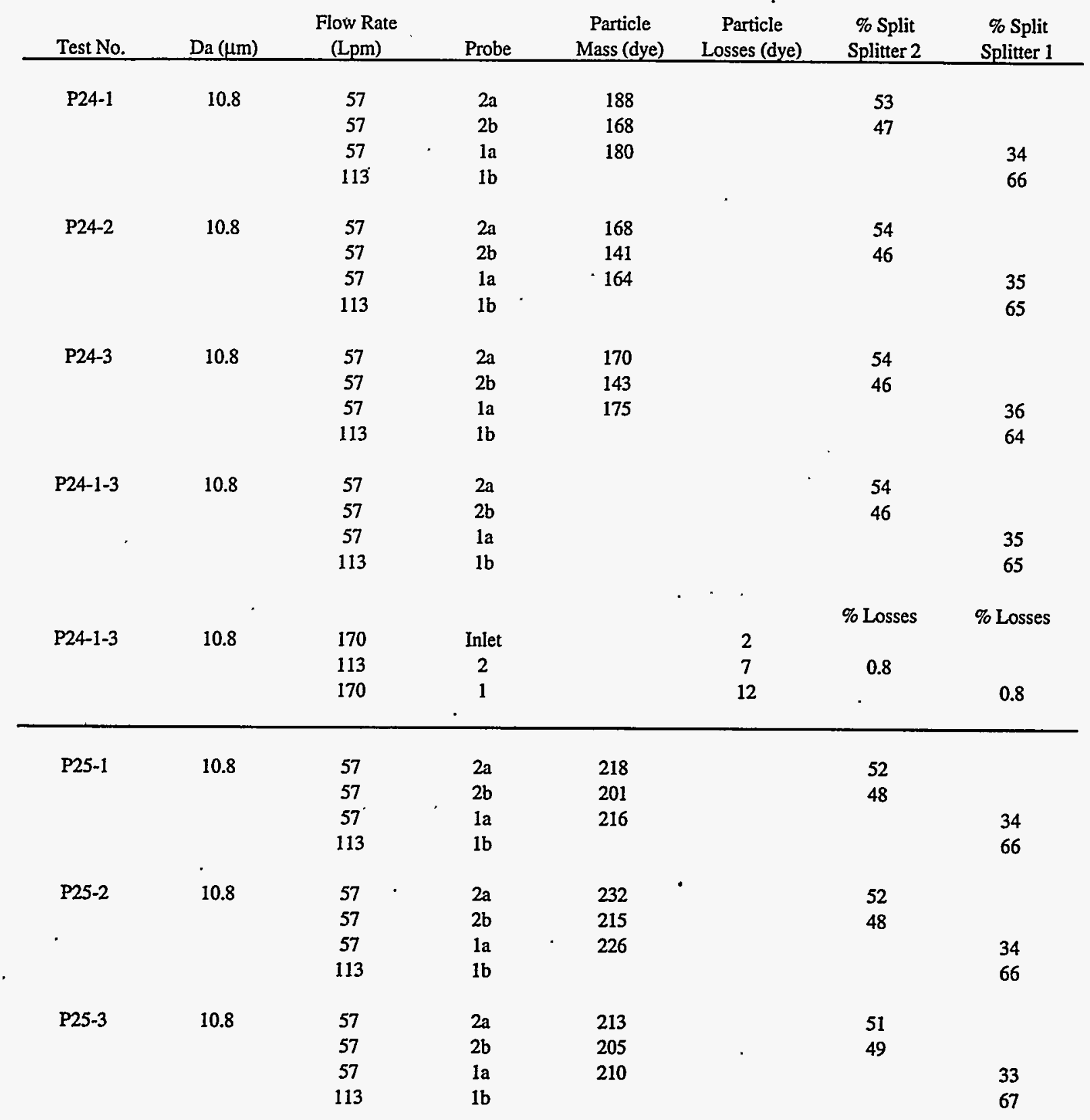

Splitter 2 connected to $113.2 \mathrm{Lpm}$ outlet leg of Splitter 1 (leg 1b). Filters located at 1a, 2a, and $2 b ; 1 b=2 a+2 b$.

Nominal flow rates (Lpm): Splitter 1 @ 169.8 (1a @ 56.6, 1b @ 113.2); Splitter 2 @ 113.2 (2a @ 56.6, 2b @ 56.6).

Sample flow rate uncertainity estimated to be $\pm 5 \%$. All sample durations $=5.00 \pm 0.05 \mathrm{~min}$.

Fluoroscopy: All results corrected to $20 \mathrm{~mL}$ dilution, scale $1 \mathrm{~A}$. Blank correction $=0$. 
Splitter Test Worksheet

\begin{tabular}{|c|c|c|c|c|c|c|c|}
\hline Test No. & $\mathrm{Da}(\mu \mathrm{m})$ & $\begin{array}{c}\text { Flow Rate } \\
(\mathrm{Lpm})\end{array}$ & Probe & $\begin{array}{c}\text { Particle } \\
\text { Mass (dye) }\end{array}$ & $\begin{array}{c}\text { Particle } \\
\text { Losses (dye) } \\
\end{array}$ & $\begin{array}{c}\% \text { Split } \\
\text { Splitter } 2 \\
\end{array}$ & $\begin{array}{c}\text { \% Split } \\
\text { Splitter } 1 \\
\end{array}$ \\
\hline P25-4 & 10.8 & 57 & $2 a$ & 214 & & 51 & \\
\hline \multirow[t]{3}{*}{. } & . & 57 & $2 b$ & 205 & & 49 & \\
\hline & & 57 & la & 210 & & & 33 \\
\hline & & 113 & $1 b$ & & & & 67 \\
\hline \multirow[t]{4}{*}{$P 25-5$} & 10.8 & 57 & $2 a$ & 209 & & 52 & \\
\hline & & 57 & $2 b$ & 196 & & 48 & \\
\hline & & 57 & la & 206 & & & 34 \\
\hline & & 113 & $1 b$ & & & & 66 \\
\hline \multirow[t]{4}{*}{ P25-6 } & 10.8 & 57 & $2 a^{\circ}$ & 242 & & 52 & \\
\hline & & 57 & $2 b$ & 223 & & 48 & \\
\hline & & 57 & $1 a$ & 259 & & & 36 \\
\hline & & 113 & $1 b$ & & & & 64 \\
\hline \multirow{4}{*}{ P25-7 } & 10.8 & 57 & $2 a$ & 205 & & 52 & \\
\hline & & 57 & $2 b$ & 188 & & 48 & \\
\hline & & 57 & $1 a$ & 207 & & & 35 \\
\hline & & 113 & $1 b$ & & & & 66 \\
\hline \multirow{4}{*}{$\begin{array}{l}\text { P25-1-3 } \\
\text { std mfm }\end{array}$} & 10.8 & 57 & $2 a$ & & & 52 & \\
\hline & & 57 & $2 b$ & & & 48 & \\
\hline & & 57 & la & & & & 34 \\
\hline & & 113 & Ib & & & & 66 \\
\hline \multirow{4}{*}{$\begin{array}{l}\text { P25-4-5 } \\
\text { alt mfml }\end{array}$} & 10.8 & 57 & $2 a$ & & & 51 & \\
\hline & & 57 & $2 b$ & & & 49 & \\
\hline & & 57 & la & & & & 34 \\
\hline & & 113 & $1 b$ & & & & 66 \\
\hline \multirow{4}{*}{$\begin{array}{l}\mathrm{P} 25-6-7 \\
\text { alt } \mathrm{mfm} 2\end{array}$} & 10.8 & 57 & $2 a$ & . & . & 52 & \\
\hline & & $57^{\circ}$ & $2 b$ & & & 48 & \\
\hline & & 57 & $1 a$ & . & & & 35 \\
\hline & & 113 & $1 b$ & & & & 65 \\
\hline \multirow{4}{*}{$\begin{array}{l}\text { P25-1-7 } \\
\text { all }\end{array}$} & 10.8 & 57 & $2 a$ & & & 52 & \\
\hline & & 57 & $2 b$ & & & 48 & \\
\hline & & 57 & la & & & & 34 \\
\hline & & 113 & $1 b$ & & & & 66 \\
\hline \multirow{4}{*}{ P25-1-7 } & & & & & & \% Losses & $\%$ Losses \\
\hline & 10.8 & 170 & Inlet & & 5 & & \\
\hline & • & 113 & 2 & & 23 & 0.8 & \\
\hline & & 170 & 1 & & 29 & & 0.7 \\
\hline
\end{tabular}

Splitter 2 connected to 113.2 Lpm outlet leg of Splitter 1 (leg $1 b$ ). Filters located at $1 \mathrm{a}, 2 \mathrm{a}$, and $2 \mathrm{~b} ; 1 \mathrm{~b}=2 \mathrm{a}+2 \mathrm{~b}$.

Nominal flow rates (Lpm): Splitter 1 @ 169.8 (1a @ 56.6, 1b @ 113.2); Splitter 2 @ 113.2 (2a @ 56.6, 2b @ 56.6).

Sample flow rate uncertainity estimated to be $\pm 5 \%$. All sample durations $=5.00 \pm 0.05 \mathrm{~min}$.

Fluoroscopy: All results corrected to $20 \mathrm{~mL}$ dilution, scale $1 \mathrm{~A}$. Blank correction $=0$. 
Splitter Test Worksheet

\begin{tabular}{|c|c|c|c|c|c|c|c|}
\hline Test No. & $\mathrm{Da}(\mu \mathrm{m})$ & $\begin{array}{c}\text { Flow Rate } \\
(\mathrm{Lpm})\end{array}$ & Probe & $\begin{array}{c}\text { Particle } \\
\text { Mass (dye) } \\
\end{array}$ & $\begin{array}{c}\text { Particle } \\
\text { Losses (dye) }\end{array}$ & $\begin{array}{c}\text { \% Split } \\
\text { Splitter } 2 \\
\end{array}$ & $\begin{array}{c}\text { \% Split } \\
\text { Splitter } 1 \\
\end{array}$ \\
\hline \multirow[t]{4}{*}{ P26-1 } & 5.5 & 57 & $2 a$ & 509 & & 50 & \\
\hline & & 57 & $2 b$ & 514 & & 50 & \\
\hline & & 57 & 1a & 529 & & & 34 \\
\hline & & 113 & $1 b$ & & & & 66 \\
\hline \multirow[t]{4}{*}{ P26-2 } & 5.5 & 57 & $2 a$ & 403 & & 49 & \\
\hline & & 57 & $2 b$ & 413 & & 51 & \\
\hline & & 57 & la & & & & $x$ \\
\hline & & 113 & $1 b$ & & & & $x$ \\
\hline \multirow[t]{4}{*}{ P26-3 } & 5.5 & 57 & $2 a$ & 416 & & 48 & \\
\hline & & 57 & $2 b$ & 454 & & 52 & \\
\hline & & 57 & 1a & 449 & & & 34 \\
\hline & & 113 & $1 b$ & & & & 66 \\
\hline \multirow[t]{5}{*}{ P26-1-3 } & 5.5 & 57 & $2 a$ & & . & 49 & . \\
\hline & & 57 & $2 b$ & & & 51 & \\
\hline & & 57 & la & & & & 34 \\
\hline & & 113 & $1 b$ & & & & 66 \\
\hline & & & & & & \% Losses & $\%$ Losses \\
\hline \multirow[t]{4}{*}{ P26-1-3 } & 5.5 & 170 & Inlet & & 2 & & \\
\hline & & 113 & 2 & & 7 & 0.3 & \\
\hline & & 170 & 1 & & 12 & & 0.3 \\
\hline & $\cdot$ & & & & & & \\
\hline \multirow[t]{4}{*}{ P27-1 } & 16.2 & 57 & $2 a$ & 97 & & 62 & \\
\hline & & 57 & $2 b$ & 60 & . & 38 & \\
\hline & & 57 & la & 51 & & & 25 \\
\hline & & 113 & $1 b$ & & & & 75 \\
\hline \multirow[t]{4}{*}{ P27-2 } & 16.2 & 57 & $2 a$ & 87 & & 63 & \\
\hline & & 57 & $2 b$ & 51 & & 37 & \\
\hline & . & 57 & la & 42 & & & 23 \\
\hline & & 113 & $1 b$ & & & & 77 \\
\hline \multirow[t]{4}{*}{ P27-3 } & 16.2 & 57 & $2 a$ & 91 & & 64 & \\
\hline & & 57 & $2 b$ & 51 & & 36 & \\
\hline & & 57 & $1 \mathrm{a}$ & 52 & & & 27 \\
\hline & & 113 & $1 b$ & & & & 73 \\
\hline \multirow[t]{5}{*}{ P27-1-3 } & 16.2 & 57 & $2 a$ & " & & 63 & \\
\hline & & 57 & $2 b$ & & & 37 & \\
\hline & & 57 & la & & & & 25 \\
\hline & & 113 & 16 & & & & 75. \\
\hline & & & & & & \% Losses & $\%$ Losses \\
\hline \multirow[t]{3}{*}{ P27-1-3 } & 16.2 & 170 & Inlet & & 3 & & \\
\hline & & 113 & 2 & & 8 & 1.8 & \\
\hline & & 170 & 1 & & 12 & & 2.0 \\
\hline
\end{tabular}

Splitter 2 connected to 113.2 Lpm outlet leg of Splitter 1 (leg lb). Filters located at $1 \mathrm{a}, 2 \mathrm{a}$, and $2 \mathrm{~b} ; 1 \mathrm{~b}=2 \mathrm{a}+2 \mathrm{~b}$.

Nominal flow rates (Lpm): Splitter 1 @ 169.8 (1a @ 56.6, 1b @ 113.2); Splitter 2 @ 113.2 (2a @ 56.6, 2b @ 56.6).

Sample flow rate uncertainity estimated to be $\pm 5 \%$. All sample durations $=5.00 \pm 0.05 \mathrm{~min}$.

Fluoroscopy: All results corrected to $20 \mathrm{~mL}$ dilution, scale $1 \mathrm{~A}$. Blank correction $=0$. 
Splitter Test Worksheet

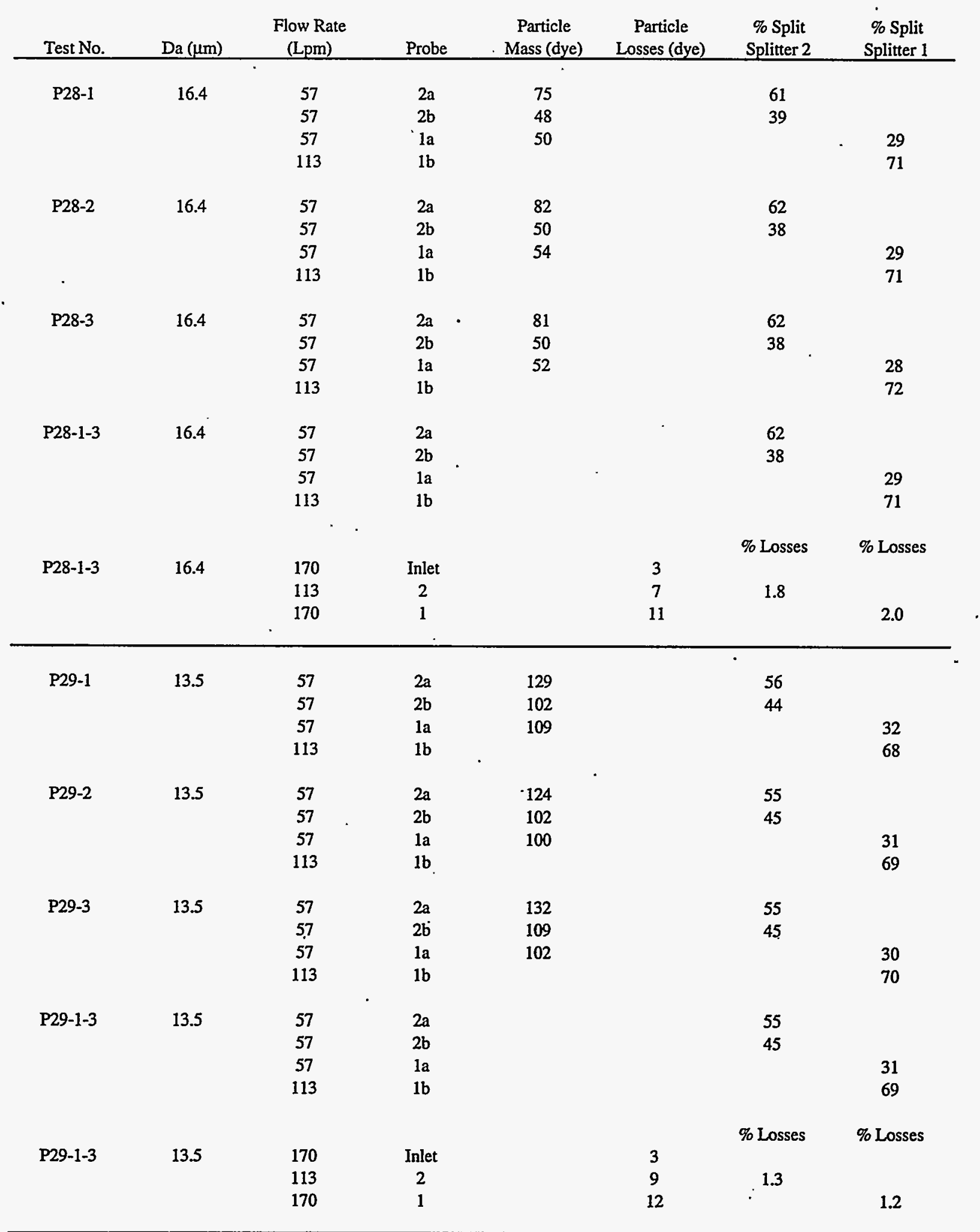

Splitter 2 connected to $113.2 \mathrm{Lpm}$ outlet leg of Splitter 1 (leg $1 \mathrm{~b}$ ). Filters located at $1 \mathrm{a}, 2 \mathrm{a}$, and $2 \mathrm{~b} ; 1 \mathrm{~b}=2 \mathrm{a}+2 \mathrm{~b}$.

Nominal flow rates (Lpm): Splitter 1 @ 169.8 (1a @ 56.6, 1b @ 113.2); Splitter 2 @ 113.2 (2a @ 56.6, 2b @ 56.6).

Sample flow rate uncertainity estimated to be $\pm 5 \%$. All sample durations $=5.00 \pm 0.05 \mathrm{~min}$.

Fluoroscopy: All results corrected to $20 \mathrm{~mL}$ dilution, scale $1 \mathrm{~A}$. Blank correction $=0$. 


\section{Distribution}

No. of

Copies

\section{OFFSITE}

12. DOE/Office of Scientific and Technical Information ,

J. L. Alvarez

International Technology Corp.

5600 S. Quebec St.,

Suite 280-D

Englewood, CO 80111

M. D. Hoover

Inhalation Toxicology

Research Institute

P.O. Box 5890

Albuquerque, NM 87185-5890

A. P. Hull

Safety and Environmental

Protection Division,

Bldg. 51

Brookhaven National Laboratory

Associated Universities, Inc.

Upton, NY 11973

J. M. Karhnak, Chief

Implementation and Technical Support Section

Criteria and Standards

Division

Office of Radiation and

Indoor Air.

United States Environmental

Protection Agency

Washington, D.C. 20460
No. of

Copies

A. R. McFarland

Aerosol Technology Laboratory

Department of Mechanical

Engineering

Texas A \& M University

College Station, TX

77843-3123

J. Mishima

SAIC

1845 Terminal Drive

Richland, WA 99352

G. J. Newton

Inhalation Toxicology

Research Institute

P.O. Box 5890

Albuquerque, NM 87185-5890

J. C. Rodgers

Health Physics Measurement

Group

Mail Stop G761

Los Alamos National Laboratory

P.O. Box 1663

Los Alamos, NM 87545

\section{ONSITE}

12 Westinghouse Hanford Company

J. D. Criddle S2-02

W. E. Davis H6-20

W. F. White (10) S2-02 
No. of

Copies

22 Pacific Northwest Laboratory

J. G. Droppo

J. A. Glissmeyer (10)

K6-55

S. J. Jette

K6-55

J. W. Leeper

P7-78

K. L. Manke

P7-63

M. J. Sula

K9-41

Publishing Coordination

SEQUIM

Technical Report Files (5)

K1-06

Routing

R. M. Ecker

P. M. Irving

SEQUIM

S. A. Rawson

K6-98

P. C. Hays

K6-81

K9-41 